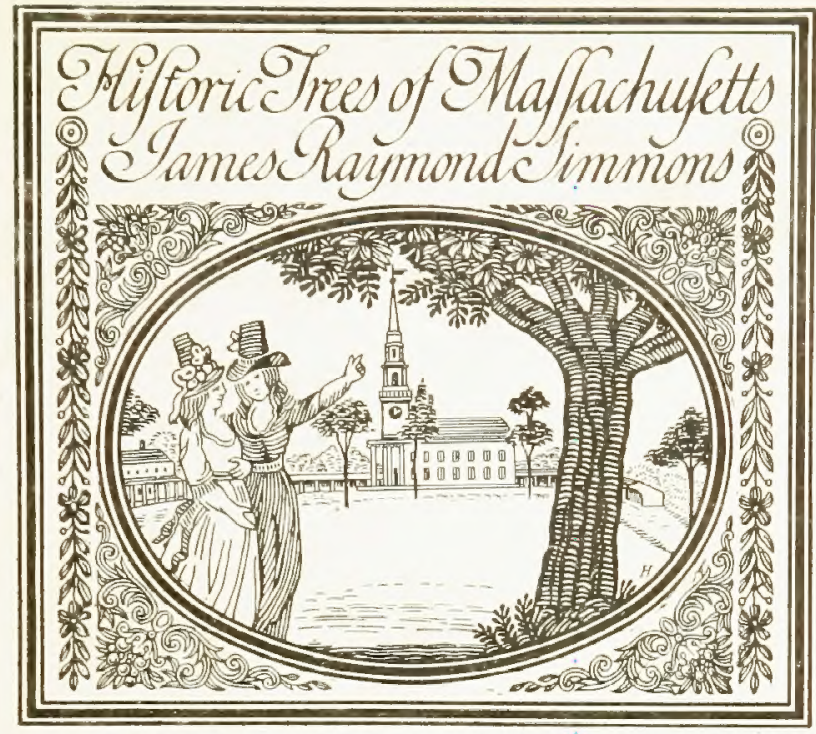




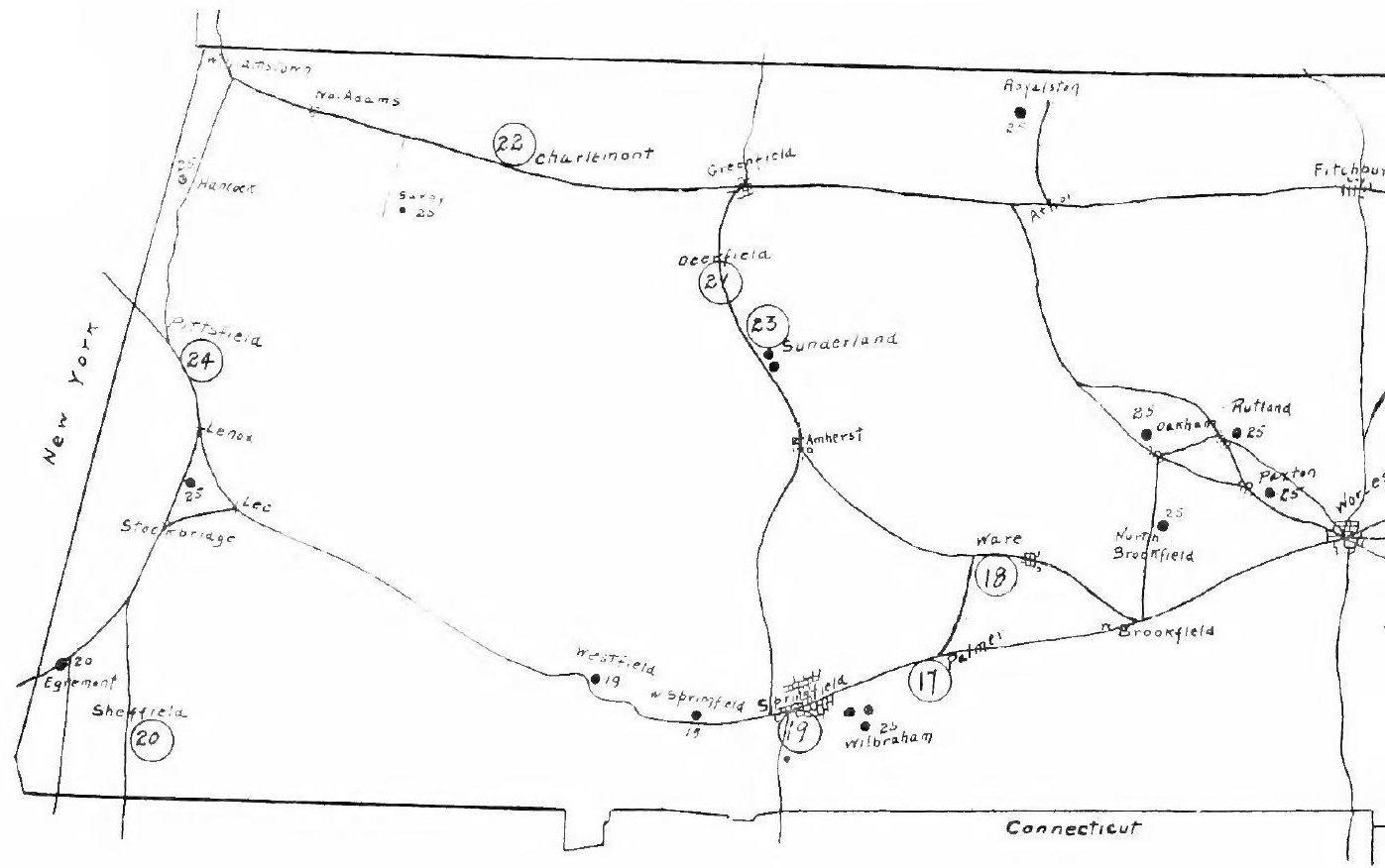

THE HISTORIG TREES OF MASSACHUSETTS.

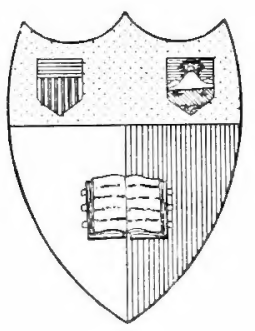

$\bigcirc$ HISTORIC TAEES, Numbers Correspond To Chapters

- OTHEA TAEES MENTIONEO IN TEXT:

ROAOS $\frac{2.4 \%}{\text { milos }}$

\section{Ãeur 其ark}

\section{tate Callege af Agrioulture}

At Corncll Bluntersity

IIthara, X̃. 10.

\section{而iltrary}




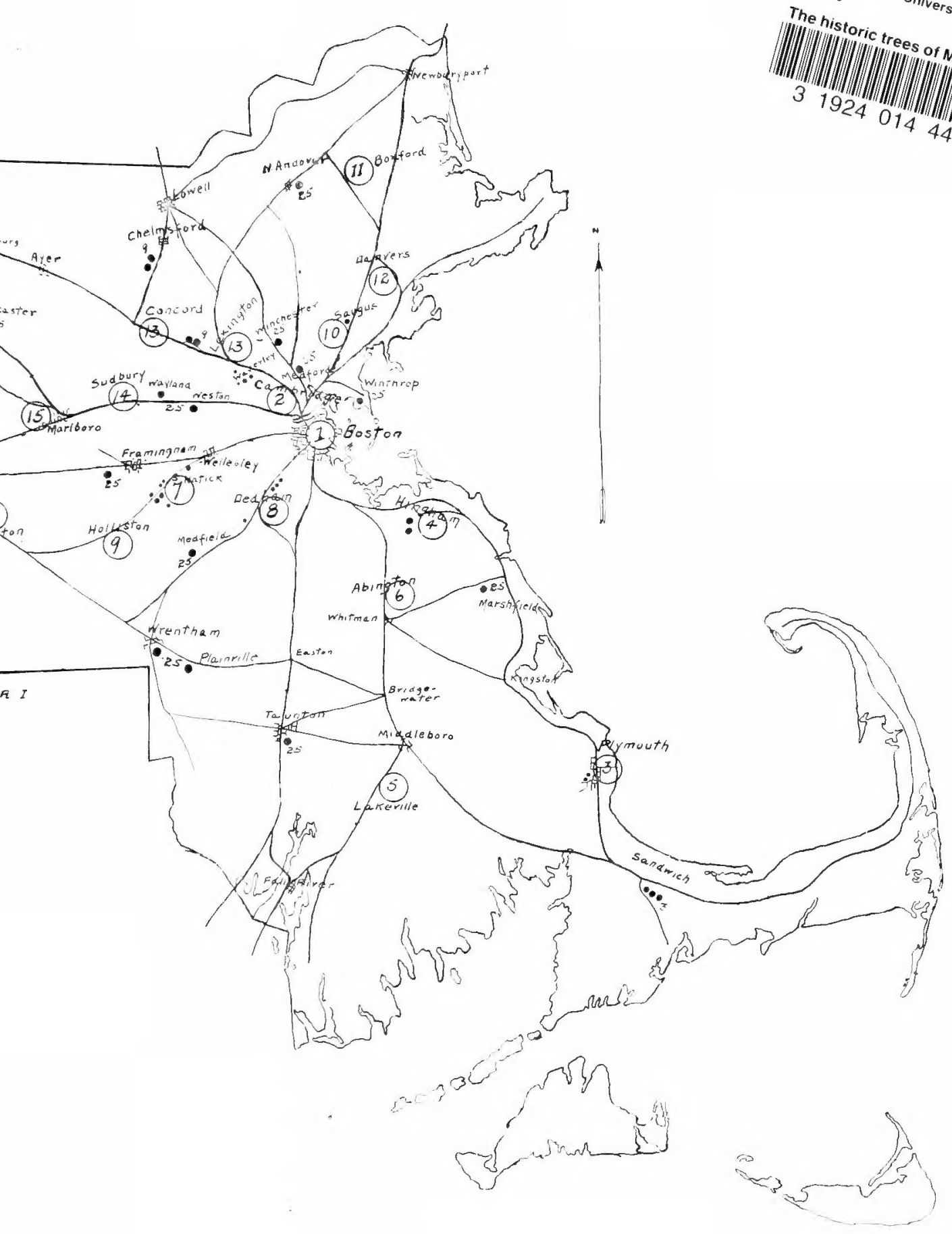




\section{Cornell University Library}

The original of this book is in the Cornell University Library.

There are no known copyright restrictions in the United States on the use of the text.

http://www.archive.org/details/cu31924014447423 


\section{THE HISTORIC TREES OF MASSACHUSETTS}






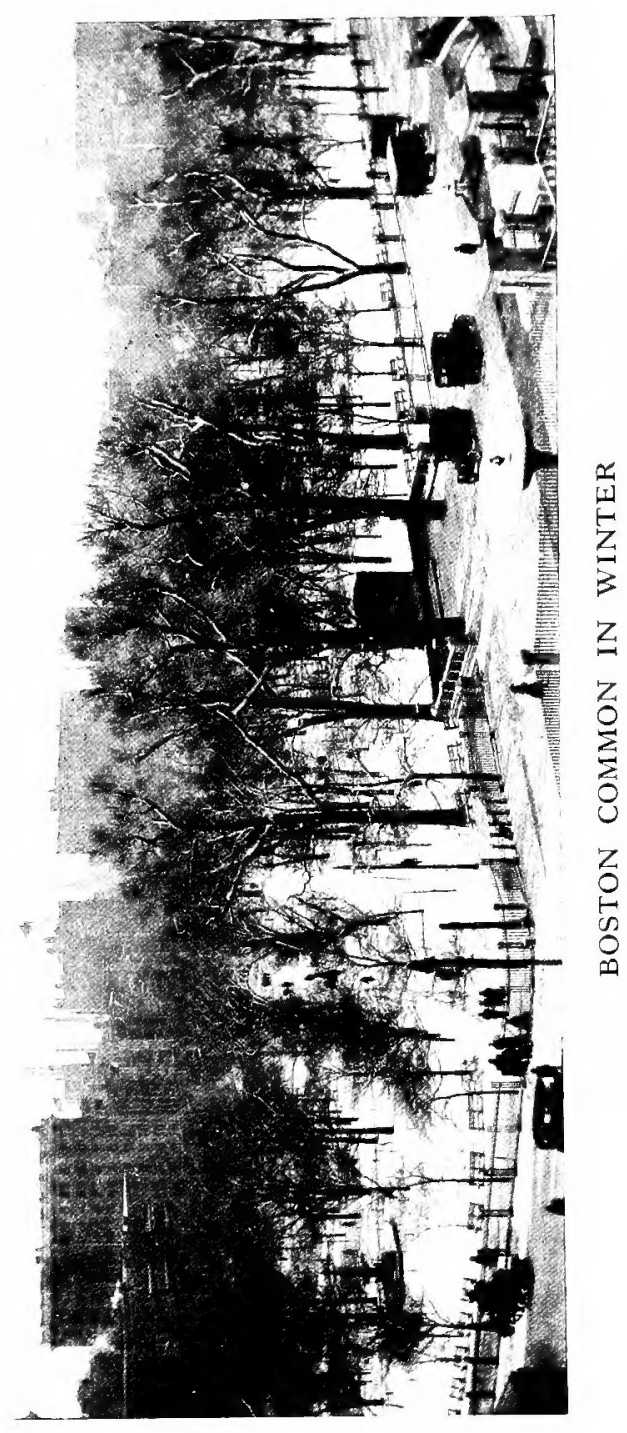




\title{
THE HISTORIC TREES OF MASSACHUSETTS
}

\author{
BY \\ JAMES RAYMOND SIMMONS
}

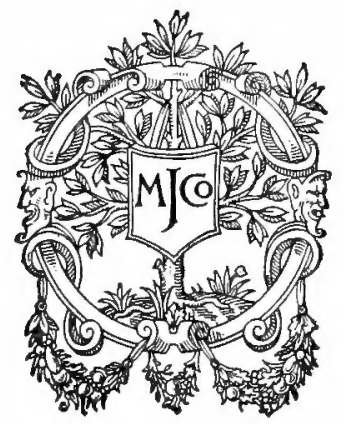

BOSTON

MARSHALL JONES COMPANY MDCCCCXIX 
COPYRIGHT, I 9 I 9

BY MARSHALL JONES COMPANY

T HE.PLIMPTON.PRES

NOR W OOD.MA S S.U.S.A 
TO

HON. ROBERT ORR HARRIS 



\section{CONTENTS}

CHAPTER

PAGE

INTRODUCTION . . . . . . . . . . . . $\mathrm{xi}$

I. The Trees of Boston Common . . I

II. The Washington Elm . . . . . Io

III. The Lindens at Plymouth . . . 17

IV. The Cushing Elm . . . . . . 26

V. The Lakeville Elms . . . . . 32

VI. Island Grove. . . . . . . . 34

VII. Eliot OAK and Other Trees of

South NAtick . . . . . . . . 39

VIII. Avery OAK and Other Trees of

Dedham . . . . . . . . 47

IX. The Holliston Elms . . . . 52

X. The Roby Elm . . . . . . . 57

XI. The Boxford Elm . . . . . . 60

XII. The Endicott Pear Tree. . . . 64

XiII. Lexington and Concord Trees . . 69

XIV. The Ancient OAks at Wayside Inn 76

XV. The Marlboro Elm . . . . . 79

XVI. The Grafton OaK . . . . . . 83

XVII. The Washington Elm at Palmer . 85

XViII. The Lafayette Elm . . . . 88 
CONTENTS

XiX. The Elm at Court Square, SpringFIELD . . . . . . . . . . 90

XX. The Sheffield Elm. . . . . . 94

XXI. Deerfield Trees . . . . . . 98

XXil. The Charlemont Buttonwood. . 103

XXIII. The Sunderland Buttonwood . I i I

XXIV. The Oliver Wendell Holmes Pine il 3

XXV. Other Well-known Trees . . II

Index to Trees . . . . . . . . . 138

[viii] 


\section{LIST OF ILLUSTRATIONS}

Boston Common in Winter............ Frontispiece

The Old Elm's Descendent, a sprout from the famous elm which fell in i $876 \ldots$ facing page 2 The Washington Elm at Cambridge. . . . . . . Io

The Lindens at Plymouth. . . . . . . . . I8

The Cushing EIm................. 26

The Lakeville EIms. . . . . . . . . . . . . . . . 32

Island Grove, Abington. . . . . . . . . . . . 34

The Entrance to Island Grove. . . . . . . . . . ${ }_{3} 8$

The Eliot Oak. . . . . . . . . . . . . . $\quad 39$

The Avery Oak.................... ${ }_{4} 8$

The Holliston Elms.................. 54

A Pair of Elms at South Chelmsford....... 55

A Pair of Elms at Lincoln............... 56

The Roby Elm. . . . . . . . . . . . . . . . . 57

The Cheever WaInut.................. ${ }_{5} 8$

The Boxford Elm.................. 60

The Endicott Pear Tree................ $6_{4}$

The Harrington EIm................ 70

The Elm at Monroe Tavern, Lexington...... 71

The Old Willow at Concord............ 74

The EIms in front of the Louisa May Alcott

House, Concord, and Hawthorne's Grove. . . . . 75 


\section{ILLUSTRATIONS}

The Ancient Oaks at Wayside Inn ......... 76

The Marlboro Elm.................. 80

The Grafton Oak.................. 84

The Washington Elm at Palmer........... 86

The Lafayette EIm. . . . . . . . . . . . . . . 88

The Springfield EIm. . . . . . . . . . . . . 90

The Sheffield Elm................... 94

The Deerfield Buttonwood.............. I

"The EIm by the Little Brown House," Deerfreld ...................... ro I

The Charlemont Buttonwood. . .......... 104

The Sunderland Buttonwood............. I I 2

The Oliver Wendell Holmes Pine. .......... I $\mathrm{I}_{4}$

The Beaman Oak.................. I 24

The Rugg Elm . . . . . . . . . . . . . . . I I 125

The EIm at West Acton. . . . . . . . . . . . I 28

The Winchester EIm. . . . . . . . . . . . . 130

The Black Walnut at West Medford......... I3 I

The Hubbard EIm. . . . . . . . . . . . . . $\quad{ }_{132}$

The Apple Tree at Marshfield Hills........ $\quad$ I 36

$[\mathrm{x}]$ 


\section{INTRODUCTION}

I stood to-day beneath a mighty tree,

And gazed upon its lofty trunk and crown,

Scarred body, branches gnarled and leaves of brown,

In silence looking upward, wonderingly.

Full oft have I thus pondered on the sea,

Or on the mountains when the sun was down,

Upon their age and grandeur, or the sound

Of rushing waters and the whispering breeze-

To waken and inspire the best in me.

Comes then the thought of those strong men I've known,

Who've stood and fought their battles, like this tree;

They know it not, but when each deed is done

Of theirs, I marvel e'en as silently,

And owe them each small victory I have won! ${ }^{1}$

J. R. S.

WROM the days of Eden, when the apple tree went on record as the first historic specimen of its kind in the world, trees have ever been closely connected with human history. If we speak from the broad standpoint of trees as a community, and seek out their influence as applied to a given portion of the earth's

1 The above quotation by the author is reprinted here by courtesy of American Forestry. 
surface, then the strength of any nation may be measured Iargely by the extent and quality of its forests; the decline of any nation usually follows the decline of its natural resources, of which the forests constitute an important part. And if we speak from the standpoint of trees as individuals, we find that certain of them are identified with events of nation-wide and even worldwide importance. Forest trees are now being systematically harvested and a new generation replaces them; individual trees, such as grow upon our lawns, along our village streets and in our meadows and pastures, live on from period to period, witnesses not only of the deeds of one but of several generations of men.

An historic tree commands in us the same quality of admiration which we feel for a great mind; it has been associated with the noted characters of its time; it is related to events whose results have affected the life and development of the community; it has demonstrated its ability to stand like a conqueror in the face of storm and adver[XII] 


\section{INTRODUCTION}

sity, and has risen superior to opposing forces of every description. We therefore honor its excellence and cherish its memory with that of our heroes!

American literature abounds with reference to great and beautiful trees, and the same may be said with equal truth of the works of the English writers. Our kinsmen across the sea have always taken an honest pride in their ancient oaks, with which the island abounds. They tell us, for example, of the great oak of Ravenshead, last survivor of old Sherwood Forest, where Robin Hood and his fearless band carried on their exploits; of the Parliament Oak, so called in memory of an assemblage of the kind held by King John beneath its shade; of the Pilgrim Oak, associated with Lord Byron, and with his father before him. Falstaff's Tree in Queen Elizabeth's walk at Windsor Forest, and Shakespeare's Tree, from which the carved box was made that enclosed the papers conveying the freedom of Stratfordon-Avon to David Garrick, are also mentioned among the famous trees of England. 


\section{INTRODUCTION}

Wise with the Iore of centuries,

What tales if there " be tongues in trees,"

Those giant oaks could tell,

Of beings born and buried here;

Tales of the peasant and the peer,

Tales of the bridal and the bier,

The welcome and farewell,

Since on their boughs the startled bird

First, in her twilight slumbers, heard

The Norman's curfew bell! ${ }^{1}$

"They are haunted with the recollections of great spirits who have sought for relaxation here from the tumult of arms, or the toils of state, or who have wooed the muse beneath their shade." 2

No small portion of the history of our own country could be told by its trees if they could speak. The silent Indian made his attack from the cover of the forest, and, if successful, often bound his victim to a tree for torture. When Braddock marched his command through the wilderness in solid formation, he would have lost every man but for the timely assistance of Washington who was familiar with the possibilities of trees as defenses, and who fought the Indians in their own method. Trees proved most

1 Fitz-Greene Halleck, "Alnwick Castle."

2 Irving, "Bracebridge Hall," "Forest Trees."

$[\mathrm{XIV}]$ 
disastrous to the British but most opportune to the Colonials on that memorable return from Concord and Lexington, April igth, 1775 .

Under the shade of a fine old elm, William Penn made his famous treaty with the Indians. The Charter Oak concealed the valuable parchment which Governor Andros demanded from Connecticut in 1687, and took its place as one of the immortals in the history of that state. And there is yet another tree, once noted for its beauty, but now only for the event which took place under its sheltering arms. The old elm at Cambridge, shorn of its glory, but still standing, marks the place where Washington took command of the American army!

These are some of the trees which have left their imprint upon the minds of millions. In addition to these, in many a sequestered spot may be found a tree, little known to the world at Iarge, and yet as dear to the heart of some worthy individual or community as the small college was to the heart of Daniel Webster. "I don't doubt," says Holmes in the "Autocrat," "there may be 
some monster-elm or other, vegetating green but inglorious, in some remote New England village, which only wants a sacred singer to make it celebrated." Trees of this type have contributed to the inspiration of more than one successful career. Some of them, long after the lapse of three-score-yearsand-ten, have clustered about themselves the fame of the man or woman who loved them, and have thereby acquired a local distinction of no unworthy proportions.

But others there are whose place in history will never be known. Events unrecorded took place beneath their boughs; in their rings of yearly growth nature has hidden the knowledge of great climatic changes and the ravages of wind and fire, written in a language with which we are but slightly familiar. The towering elm of Pittsfield, the two beautiful elms of Springfreld and many others, irresistible in their time, have passed away; but their fame is secure, for they have been rendered immortal by many authors. The value of each lay not so much in its connection with [XVI] 


\section{INTRODUCTION}

known historic events as in its influence over those who gazed upon its stately form, and received, therefrom, a vision.

The following pages will bring before the observation of the reader in a fairly comprehensive way, all trees generally known as bistoric in the Commonwealth of Massachusetts, together with the principal events connected with each of them. A goodly number of typical trees which have no historic connections, other than those arising from age, beauty or location, are also included in the text.

It is usually conceded that a tree beneath whose shade some event of significance in the life of the State or the Nation took place is an bistoric tree. The Charter Oak and the Washington EIm above mentioned may be cited at random as good examples of this type of landmark. The definition should also include any tree rendered famous by a noted personage, leader or pioneer Daniel Boone's "Bar Tree" for example."

1 The Charter Oak and the "Bar Tree" are, of course, not connected with Massachusetts, but are cited for the purpose of making the definition perfectly clear.

[XVII] 
Massachusetts, on account of the fact that it is one of the oldest states in the Union, and because of the unusual number of places of historical interest which it contains, offers remarkably good territory from which to select famous trees. The "Bay State," moreover, lies in the center of that section of the country which seems to be especially loved by and devoted to the Ulmus Americana (American Elm). No less than twenty splendid examples of this species are here cherished on account of the deeds they commemorate; some of these have spent their entire life on the spot where nature first placed them; ${ }^{2}$ but the majority of the celebrated elms were dug from the frelds when mere seedlings and transplanted to new situations along the main streets and highways, or in front of dwelling houses that have long since found a place in the Nation's history. The white oak (quercus alba) is second in importance to the eIm, while the third place is about equally divided

${ }^{2}$ For example, the Great EIm mentioned in Chap. I, and the Washington Elm mentioned in Chap. 2 are said to have been remnants of the original forest.

[XVIII] 
between the sycamore or buttonwood (Platinus occidentalis) and the red oak (Quercus rubra). Noble specimens of the white pine (Pinus strobus), the chestnut (Castanea dentata) the European linden (Tilia vulgaris), the willow (Salix nigra), the black walnut (Juglans nigra) and the hackberry (Celtis occidentalis) also abound. And the reader will be interested to know that there still stands an historic pear tree, boasting the ripe old age of two hundred and ninety years.

The present volume is concerned, primarily, with trees of established celebrity, and may be said to be a brief historical treatise covering the period previous to the Civil War, and written from the standpoint of trees as witnesses of the events herein chronicled. Some individual specimens have doubtless been overlooked, and other facts than those recorded here may be known by the oIdest inhabitant. The author has, however, attempted to seek out the best known trees throughout the whole area of the state, and to surround them with the best known facts. Historic data have been 


\section{INTRODUCTION}

gleaned from town and county histories, selectmens' reports, newspapers, and many other sources, and reproduced without any attempt at exaggeration. The arrangement of chapters, with exception of the last, is based on geographical situation, with Boston as a starting point.

For a clear understanding of the measurements, which are given for each historic tree and for the majority of the others, the following points may be noted:-Circumferences are taken at breast height, or four and a half feet from the ground, unless otherwise stated. (Some authorities favor frve feet, and others give circumferences at varying points on the trunk.) Heights are measured from the ground to the end of the topmost branch, with a hypsometer; and spread signifies the greatest extent of the branches, measured in a straight line outward from the trunk on both sides.

All photographs were taken by the author with a $3 \mathrm{~A}$ Brownie camera. Trees which show no leaves were photographed in winter or early spring.

[xx] 


\section{INTRODUCTION}

Care has been exercised in the giving of full credit for data and quotations, even at the expense of good diction. The author also wishes to acknowledge, herewith, his indebtedness to all persons who have contributed to the work by the answering of questions, the loan of books and records of all descriptions, and by their enthusiastic support and encouragement; he is especially indebted to Prof. George M. Dutcher, PH.D., of Wesleyan University, for a criticism of the manuscript and for many valuable suggestions.

$$
\text { J. R. S. }
$$





\title{
THE HISTORIC TREES OF MASSACHUSETTS
}

\author{
CHAPTER I \\ THE TREES OF BOSTON COMMON \\ Deep and wide \\ The wheels of progress have passed on; \\ The silent pioneer is gone, \\ His ghost is moving down the trees, \\ And now we push the memories \\ Of bluff, bold men who dared and died \\ In foremost battle, quite aside.
}

Joaquin Miller

THE Duke of Wellington said, 'Waterloo was won on Eton's playgrounds!'

1 And boys who have coasted on the long malls of Boston Common, played upon its ball-grounds, and received inspiration from orations of great statesmen, and from the frequent military parades there have afterward stormed many heights in the military service of their country. Many a hero of our navy has sailed his first boat in the "frog pond." " 
THE HISTORIC TREES OF MASSACHUSETTS

These words were spoken by a Bostonian at the annual meeting of the American Park and Outdoor Art Association at Detroit, in June, 1899. ${ }^{1}$ He was speaking from the standpoint of the Common as a city park, the first of its kind in the country; he conveyed to his hearers the thought that "the trees of the Boston Common are historic trees, because the Common itself is historic."

The earliest record of famous trees within the bounds of the Common is Bonner's map of 1722, which gives the location of the Great Elm (picturing it as of unusual size) and of a group of elms at the corner of what are now Washington and Essex streets. One of these was the famous Liberty Tree. The scene has been a constantly changing one through the years that have followed since this early map of Boston was made, for practically every tree now standing on the "peninsula" was placed there by the hand of man. The Liberty Tree was destroyed by the British in 1775 , while the Great EIm, the true native and king of the Common, survived until

1 Edward A. Parker

$[2]$ 


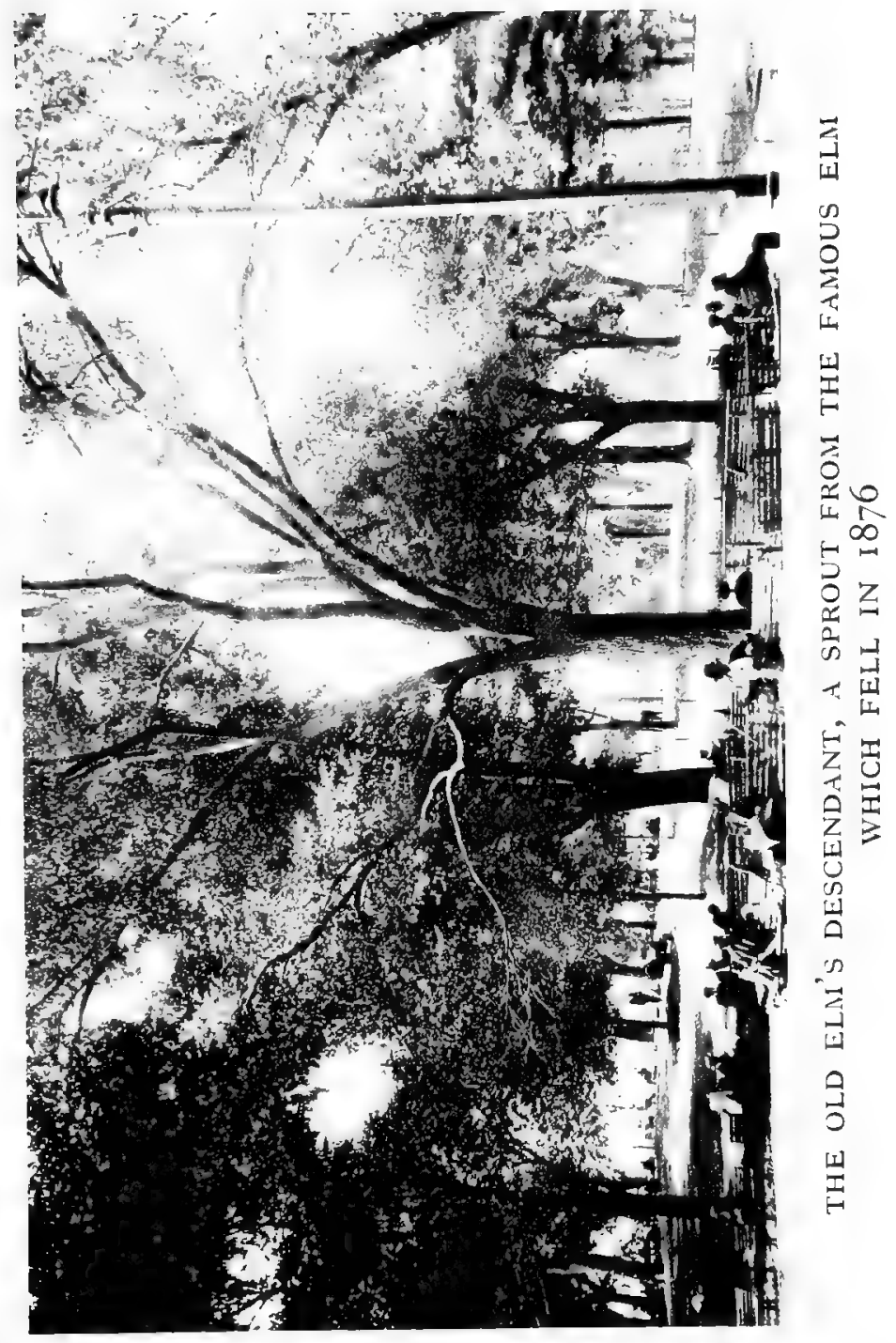




\section{-}


THE TREES OF BOSTON COMMON

I876, when it fell in a gale on the fifteenth of February of that year. A local historian says of this tree, "What I am is of little consequence; what I have seen and known is identified with the human race." ${ }^{1}$ And concerning the other landmark, Lafayette, when in Boston, said, "The world should never forget where once stood Liberty Tree so famous in your annals!"

There has arisen on the site of the Great EIm, and from its roots, a sprout generally known as "the old elm's descendant." It is now a lusty tree $6 \frac{1}{2}$ feet in circumference, and is surrounded by an iron enclosure. Two inscriptions have been erected at its base, one in commemoration of the parent tree, and the other descriptive of the offshoot that stands in its very footprints.

\section{THE OLD ELM}

THIS TREE HAS BEEN STANDING HERE FOR AN UNKNOWN PERIOD.

IT IS BELIEVED TO HAVE EXISTED BEFORE THE SETTLEMENT OF BOSTON, BEING FULLY GROWN IN 1722, EXHIBITED MARKS OF OLD AGE IN I792,

1 Mass. Historical Society Proceedings, vol. 14, p. 300. 
THE HISTORIC TREES OF MASSACHUSETTS

WAS NEARLY DESTROYED BY A STORM

IN 1832. PROTECTED BY AN IRON

ENCLOSURE IN I854.

J. V. C. Sмith, Mayor.

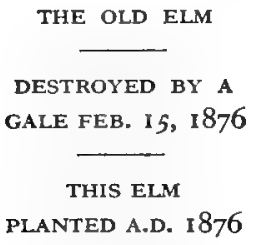

In the wall of a building at the southeast corner of Essex street at its junction with Washington street there was inserted some years ago by Mr. David Sears a handsome freestone bas-relief representing the Liberty Tree. This memorial is placed directly over the spot where the original tree stood, and an inscription informs the reader that it commemorates

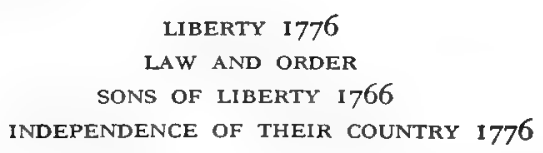

These memorials mark the passing of the trees of individual fame on Boston Common. The records show that Liberty Tree produced fourteen cords of wood, while the Great Elm was so large that one of its huge limbs, blown off in I860, showed one hun[4] 


\section{THE TREES OF BOSTON COMMON}

dred and ninety annual rings. The oldest trees now standing on this historic ground are slightly over one hundred years old. There is something very typical of democracy in the present arrangement, where every tree is accorded equal attention and care, and shares with every other its "place in the sun."

The Common of the present time is entirely surrounded by "malls" all of which have names derived from the streets which form their outer boundaries. That on Tremont street is the oldest and was therefore originally named the mall; although subsequently, when there was a second one it acquired the name of the great mall, and now, as there are several, it is called the Tremont street mall. Early in the eighteenth century it had two rows of trees, mostly English elms, with a few sycamores at the northerly and some poplars at the southerly end, the outermost of which was set out about the year 1734. In 1784 John Lucas, Esq., the commissary of pensions for Massachusetts, who resided and had his 
THE HISTORIC TREES OF MASSACHUSETTS office in Orange street, and Mr. Oliver Smith, a noted apothecary who dwelt in Milk street, procured subscriptions to the amount of $£_{2} 85$ I 45 7d for the improvement of the Common; and to the efforts of these men the town was indebted for the third row of trees in Tremont street mall. New trees have been added as the older ones declined, until, at the present time, the great mall is composed almost entirely of young stock. The Beacon street mall was Iaid out in 1815 and 1816 , and the expense was defrayed from a subscription raised in $18 r_{4}$ for the purpose of defense against a contemplated attack from the British. Here may be found the oldest trees on the Common. Surrounding Shaw's monument and extending west along the mall is a group of eight English elms the largest of which has a circumference of about fourteen feet. There is also a very fine gingko near the Curtis Guild memorial steps. Beyond this point looking west American elms form a canopy of shade quite to the end of the mall. The Charles street mall was commenced in [6] 
I823 and completed in I824, during the first year of the mayoralty of the eider Quincy, and in 1826, through the energy of that gentleman, the old poplar trees that used to disfigure Park street, were unceremoniously cut down in the early morning hours, and beautiful elms set out in their place by his own hands. Only a few of these elms now remain, but their places have been filled by younger trees. In 1836 BoyIston street mall was extended across the burial ground, two rows of tombs being closed for the purpose; and with this improvement the Common became for the first time entirely surrounded with trees. ${ }^{1}$

In 1871, when Dr. Shurtleff's "Historical and Topographical Description of Boston" was published, there were, he says, about 1300 trees in all, of which 700 were American elms, 50 English and Scotch elms, 70 lindens, I 7 tulip trees, I o sycamores, 8 oaks, 4 balsam poplars, and a large variety of other trees. In 1864 all the trees of the Common were

1 Shurtleff, "Historical and Topographical Description of Boston." 
THE HISTORIC TREES OF MASSACHUSETTS

scientifically examined by Dr. A. A. Gould and their species ascertained; and upon some of the best specimens labels were fastened indicating the popular and scientific names. A list of other trees which should be procured was also submitted, and with it definite information as to where they could be obtained. This program has been consistently carried out, seemingly in the spirit of the words of the orator who, addressing a large audience under the branches of the Great EIm a half century ago, cried out, "We will elect only the men for city councillors who will guard every tree on these grounds!"1

Several new paths, or malls, have been Iaid out during recent years. The usual practice has been for the mayor of the city to plant the first tree. Liberty Mall is the most recent undertaken and extends, approximately, from the Shaw Memorial on Beacon street near the State House to Tremont street near the subway entrance. The point of intersection of these two malls has 1 Rev. L. B. Bates.

\section{[8]}


THE TREES OF BOSTON COMMON

become the historic center of the Common. Probably no other spot in the United States has seen so many thousands of men recruited for military service, under the American, English and French Flags, or so many millions of money contributed for the cause of human liberty!

[9] 
CHAPTER II

THE WASHINGTON ELM

Of our swift passage through this scenery

Of life and death more durable than we,

What landmark so congenial as a tree

Repeating its green legend every spring,

And with a yearly ring

Recording the fair seasons as they flee,

Type of our brief but still renewed mortality?

Lowell

WHERE is probably no tree dearer

to the hearts of the people of Massa-

chusetts, or even of the country at

large, than the Washington Elm at Cambridge. If it is true that the Arabs of the desert tell their children the story of Washington, the father of his country, it is equally true that travelers from every leading nation of the world have looked with reverence upon this spreading elm, and pondered long as they read the inscription on the monument at its base. Artists have painted it, poets have sung its praises, and most historians who have written of the [10] 


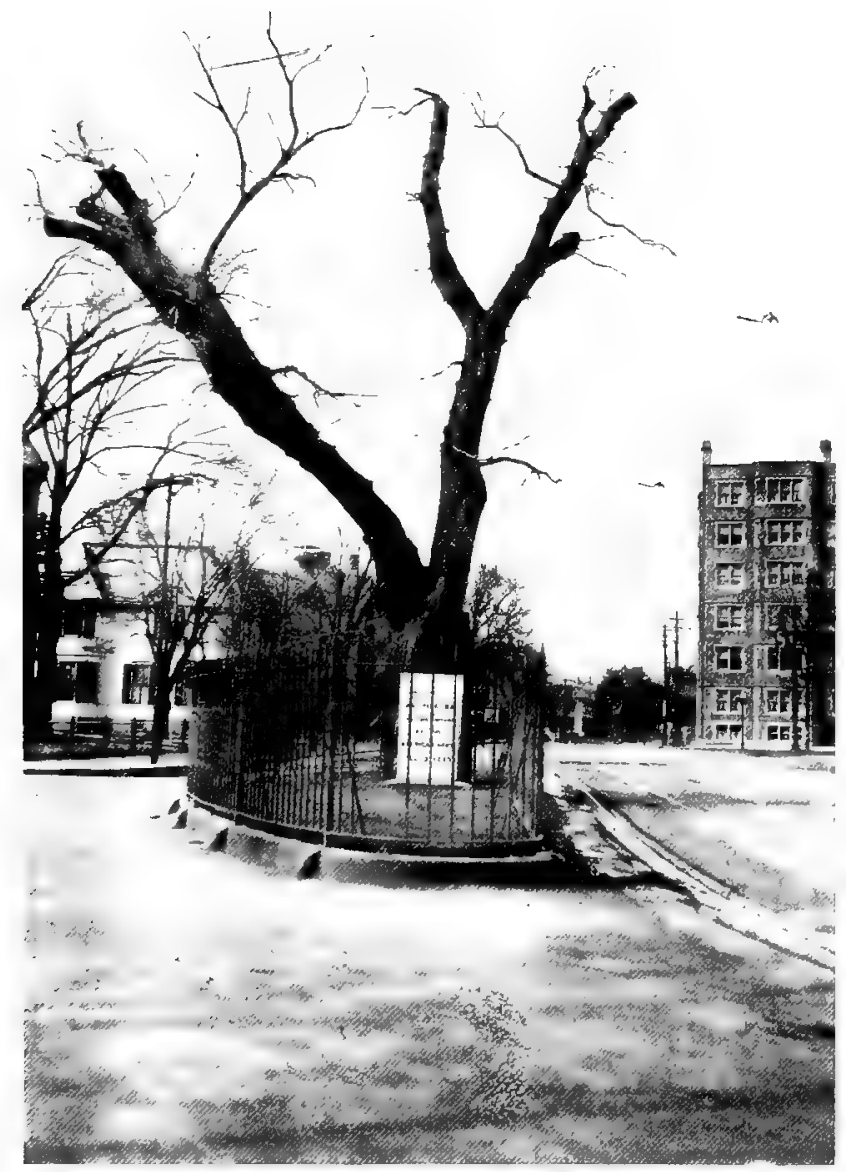

THE WASHINGTON ELM AT CAMBRIDGE 

THE WASHINGTON ELM

Revolution remind us that "under its branches Washington took command of the Continental Army on the third of July, I775."

The Cambridge eIm leaped into fame as a result of the opposition to British oppression expressed in Boston, and the necessity for a nationally recognized military organization equal to meeting the needs of the time. Until 1775 the Colonies were without a commander-in-chief. In reviewing the period, in an article on American historical trees, Harper's Montbly for May, I862, says: "The thunder peal of revolution that went forth from Lexington and Concord aroused all New England and a formidable army was soon gathered together around Boston, with a determination to confine the British invader to that peninsula or drive him into the sea. The storm cloud of war grew more portentous every hour. At length it burst on Bunker Hill, and the great conflict for American Independence began. The patriots looked for a competent captain to lead them to absolute freedom and peace. 
THE HISTORIC TREES OF MASSACHUSETTS

That commander was found in George Washington of Virginia. A New England delegate suggested him, ${ }^{1}$ a Maryland delegate nominated him $^{2}$ and the confederate congress appointed him commander-in-chief of all "the Continental forces raised or to be raised for the defense of American liberty." The army at Boston was adopted as the army of the nation; and on the twenty-first of June, 1775, Washington left Philadelphia for the New England capital to take command of it. He arrived at Cambridge and made his headquarters there, the second of July. $\mathrm{He}$ was accompanied by Major-general Lee, his next in command, and other officers, and received the most enthusiastic greetings of the people on the way. At about nine o'clock on the morning of the 3rd of July, Washington, accompanied by the general officers of the army who were present, proceeded on foot from the quarters of the Commander-in-chief, to a great elm tree at the north of the Cambridge Common, near which the Republican forces were drawn

1 John Adams.

2 Thomas Johnson.

$[12]$ 
up in proper order. Under the shadow of that wide-spreading tree, Washington stepped forward a few paces, made some appropriate remarks, drew his sword and formally assumed the command of the army."

Irving, as well as other writers, differs slightly from this account in certain details. There was a considerable amount of discussion in the Continental Congress at the time of Washington's appointment concerning who should be the "next in command." Irving says that because of the rank, character and experience of Generals Lee and Ward their supporters were unwilling that either should serve as a subordinate to any general but Washington, and that, for this reason, Ward was at last elected second, and Lee third in command. Ward was at that time the commander at Boston. ${ }^{1}$ This historian also states that Washington "wheeled his horse, and drew his sword as commander-in-chief of the armies." But whether the great man took command of 1 Irving, "Life of Washington," vol. 1, p. 29I. Frothingham's "Siege," p. 214. 
THE HISTORIC TREES OF MASSACHUSETTS

the American army on foot or on horseback it is certain that he did it with dignity, under the elm which bears his name; and our hearts beat faster as we contemplate the wonderful picture.

More than a hundred and forty years have come and gone since that important and imposing event took place, and the Washington Elm still stands! It is with profound sorrow that we find ourselves confronted with the knowledge that it is now but a shadow of its former self. It has become the victim, like many another tree of its kind, of the leopard moth and the elm-leaf beetle. Every effort has been made to save it, but it is not expected to last for more than another decade.

The Harvard Book describes this tree as belonging to the forest which originally covered the locality in which it stands, and gives its dimensions as nearly roo feet in height, over 18 feet in trunk circumference and 90 feet in the spread of its branches. The measurements for height and spread have been greatly reduced as a result [I4] 
THE WASHINGTON ELM

of pruning during the last few years. "In August, 1872 , a branch 17 inches in diameter fell from the tree. A part of the wood was used in making a pulpit for the chapel of the neighboring church." Previous to this first indication of old age, on Nov. 30 , I864, the City Council ordered "that the committee on Public Property cause a suitable tablet of some durable material, either granite, marble or iron to be placed on the 'Washington Elm' in Ward I, said tablet to commemorate in conspicuous letters the Revolutionary event which rendered said tree historical."

And so we might go on, and recall from abundant sources the history of one of the oldest Iandmarks of Massachusetts. A great number of our representative men have mentioned it in public utterance or written word at some time in their careers, and in the heart of every American who loves the history of his country, there dwells a degree of respect and gratitude for this living representative of olden time. Lowell's was a fitting tribute when he wrote,

$$
\text { [15] }
$$




\section{THE HISTORIC TREES OF MASSACHUSETTS}

Words pass as wind, but where great deeds are done

A power abides transfixed from sire to son;

The boy feels deeper meanings thrill his ear,

That tingling through the pulse life-long shall run,

With sure impulsion to keep honor clear,

When, pointing down, his father whispers, "Here,

Here, where we stand, stood he, the purely great,

Whose soul no siren passion could unsphere,

Then nameless, now a power and mixed with fate."

Historic town, thou holdest sacred dust,

Once known to men as pious, Iearned, just,

And one memorial pile that dares to last;

But Memory greets with reverential kiss

No spot in all thy circuit sweet as this,

Touched by that modest glory as it passed,

O'er which yon elm hath piously displayed

These hundred years its monumental shade. 


\section{CHAPTER III}

\section{THE LINDENS AT PLYMOUTH}

The breaking waves dashed high

On a stern and rock-bound coast,

And the woods against a stormy sky,

Their giant branches tossed;

And the heavy night hung dark,

The hills and waters o'er,

When a band of exiles moored their bark

On the wild New England shore.

Felicia Hemans

\ANY a person has wondered, during his thoughtful moments, whether any of his ancestors came to America in the Mayflower, and in spite of himself has experienced a growing sense of pride in the discovery that he was in some way connected with those men "who produced a greater revolution in the world than Columbus." "That daring navigator," says one historian, "in seeking India, discovered America. They in pursuit of religious freedom, established civil liberty, and meaning only to found a church gave birth to a nation, 
THE HISTORIC TREES OF MASSACHUSETTS

and in settling a town, commenced an empire!"' In like manner, any person whether Mayflower descendant or not, who claims America as his own, his native land, has found occasion to glory in "the consummate prudence of Bradford, the matchless valor of Standish and the incessant enterprise of Winslow."

Not only have the writers of our country given praise to whom praise is due, but those of other lands have recognized in the coming of the Pilgrim fathers an inspired event. Such a writer was Carlyle, who said, "Hail to thee, thou poor little ship 'Mayflower'! poor, common-looking ship hired by common charter-party for coined dollars, calked with mere oakum and tar, provisioned with vulgar biscuit and bacon; yet what ship 'Argo' or miraculous epic ship built by the sea-gods was other than a foolish bombarge in comparison? Golden fleeces or the like they sailed for with or without effect. Thou little 'Mayflower' hadst in thee a veritable Promethean spark - the spark of the largest

1 Baylie's "New Plymouth," Preface

[1 8$]$ 


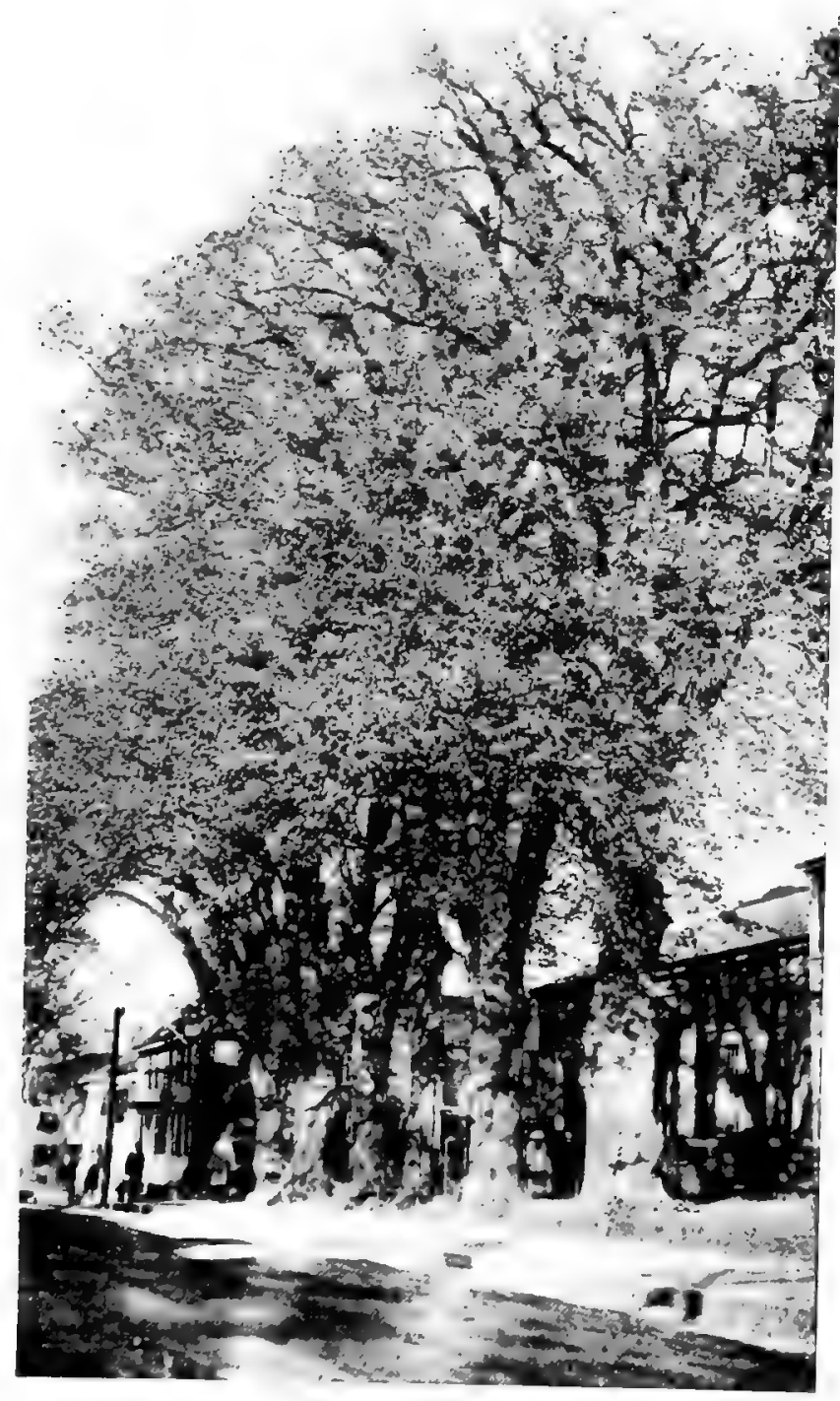

THE LINDENS AT PLYMOUTH 

nation of our earth, as we may already name the transatlantic Saxon nation. They went seeking leave to hear a sermon in their own method, these 'Mayflower' Puritans a most indispensable search; and yet like Saul the son of Kish, seeking a small thing they found this unexpected great thing. Honor to the brave and true! They verily, we say, carry fire from heaven, and have power they dream not of. Let all men honor Puritanism, since God has so honored it."

What manner of trees were those which tossed their giant branches against the stormy sky as the Pilgrims Ianded? Not the lindens, with which this chapter is concerned, but pine and oak, chestnut and walnut, even on Cape Cod. With undaunted zeal these men and women accepted the task before them and conquered the land and the forest as weIl as their enemies. There is a tradition in the old town that the Pilgrims brought with them specimens of their favorite trees. At any rate, when the community began to assume the proportions of a town and definite streets were laid out, 
THE HISTORIC TREES OF MASSACHUSETTS

European trees made their appearance. Most of the native trees had been cut and hewn into timbers for homes. Invariably the linden and English oak were the species selected and imported for shade-tree planting. Both of these varieties grew beautifully in the mother country, and it may be said that Holland, where the Pilgrims sought a refuge before coming to America, has been called "the country of lindens." Certainly the planting of such trees in the New World was a mark of affection for things held dear in the OId, and the symbol of a friendship which even the misunderstandings of RevoIutionary times could not shatter. America abounds with oaks, lindens and elms thus planted.

To obtain a clear idea of the type of men who were most responsible for the estabIishment of the European trees in Plymouth we must look forward a period of years to that era of peace and accomplishment which followed the Revolution. It was then that the real character of these men asserted itself. They were marked by other dis[20] 


\section{THE LINDENS AT PLYMOUTH}

tinctive qualities than those associated with war or commercial enterprise, and were responsible for the civil reform and wealth which developed so rapidly in Plymouth as the settlement grew. Like many such periods, whether in the life of a community or a nation, it developed liberal, publicspirited citizens. The leaders devoted themselves with pride, heart and soul to the welfare of the town. They elected faithful and dignified offrcials, and without regard to social rank administered to the needs and welfare of their neighbors and fellowtownsmen. ${ }^{1}$ Such were the men who, in their younger days, devoted themselves, among many other acts, to the noble work of tree planting.

Among those who arrived at old age during this period of civic growth was Colonel George Watson, ${ }^{2}$ of whom the inscription on his gravestone says,

With honest fame and sober plenty crowned, He lived and spread his cheering influence round.

1 Hurd, "Hist. of Plymouth County," pp. I56-7.

2 Died in 1800 , aged 83 . 
THE HISTORIC TREES OF MASSACHUSETTS

CoI. Watson, when a young man, imported through a Boston sea-captain named Cameron, severaI linden trees from London, and planted them in the garden behind the house which he built on the site of the present Hathaway house, about $1745 .{ }^{1}$ Some of the original trees remain and are among the finest of their kind in the country. The row on the street was taken from them and set out about fifteen years Iater. There are eight trees in this row and they bear an inscription at either end of the group which reads,

$$
\begin{gathered}
\text { LINDEN TREES } \\
\text { PLANTED BY } \\
\text { COL. GEORGE WATSON } \\
\text { I760 }
\end{gathered}
$$

Many lindens have sprung from this same stock, and without doubt the beautiful tree standing on the knoIl above the "Plymouth Rock" came from this source. W. T. Davis, in his "Memoirs of an Octogenarian," writes of this tree in the following interesting way:

"The linden tree standing on the corner

1 Davis, "Historical Sketch and Titles of Estates," p. I8I.

[22] 
of Cole's Hill has an interesting romance associated with it. The tree was planted by a youthful couple as a memorial of their engagement, and when not long afterwards, in 1809 , the engagement was discontinued, and the memorial was no Ionger prized by the lady in whose garden it had been planted, she one day pulled it up and threw it into the street. My father, who happened to be passing at the time, picked it up and planted it where it now stands. He lived in the house now known as the Plymouth Rock House, where he died in 1824, and under his careful nursing it survived its treatment, and has grown into the beautiful tree, now blessing so many with its grateful shade. In that house I was born in 1822 , and lived until I was more than twenty years of age, and hundreds of times I have climbed the branches of the Linden, often with book in hand, seeking shelter from the summer sun." 1

Other trees in Plymouth worthy of mention are the elms in the town square, planted 1 Davis, "Memoirs of an Octogenarian," p. 15. 
by Thomas Davis, ${ }^{1}$ the frne old eIm in front of the Court House, and the huge elm on North St., just below the linden trees. There is also a very old English oak near the Jackson homestead, formerly Gov. Winslow's house, where Lydia Jackson, wife of Ralph Waldo Emerson was born.

The lindens all appear to be in good condition. They have withstood the blasting winds from a broad expanse of sea for a century and a half, and under the same conditions may live for another century to come. The two which stand in the garden behind the Hathaway house (I I North St.) are seventy feet high. One measures fourteen feet and three inches, and the other nine feet and eight inches in circumference at four and a half feet from the ground. There were originally four trees, planted in a row; one blew down, and one was cut by Mr. Hathaway to make room for the two remaining trees. A Iarge branch, about a foot in diameter, fell from the Iarger tree during a storm in September, 1909. The ${ }^{1}$ Great-grandfather of W. T. Davis. 


\section{THE LINDENS AT PLYMOUTH}

row on the street averages a little over sixty feet in height, and the circumferences at four and a half feet from the ground, beginning with the tree at the upper end of the row, are as follows:

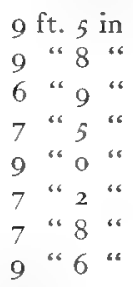

The linden standing on Cole's Hill is thirteen feet and six inches in circumference, and while only about fifty feet in height possesses a broad, spreading crown of over sixty feet.

It may be added, in closing this chapter, that the Plymouth lindens are rivaled in size and spread by a group of three on the Cotuit road on the southern side of the town of Sandwich. The Iargest of these is about I 5 feet in circumference, and is the very counterpart of the linden on Cole's Hill, Plymouth, just described. 


\section{THE CUSHING ELM}

Who does his duty is a question

Too complex to be solved by me,

But he, I venture the suggestion,

Does part of his that plants a tree.

\section{Lowell}

WHE summer tourist on his way to Cape Cod has often passed through 1 the portion of Hingham lying just to the south of Nantasket Junction near the Cohasset town line. He has noticed, on the right hand side of the road, a very large and symmetrical tree, known as the Cushing EIm, bearing the following inscription:

UNDER THIS TREE IN I775

PASTOR JOHN BROWN PREACHED

TO A COMPANY OF COHASSET SOLDIERS

OF COL. GREATON'S REGIMENT WHICH

SERVED IN THE SIEGE OF BOSTON

Colonel Greaton was in command of that portion of the Patriot army which was located at Roxbury in 1775, and his name occurs many times in connection with mili[26] 


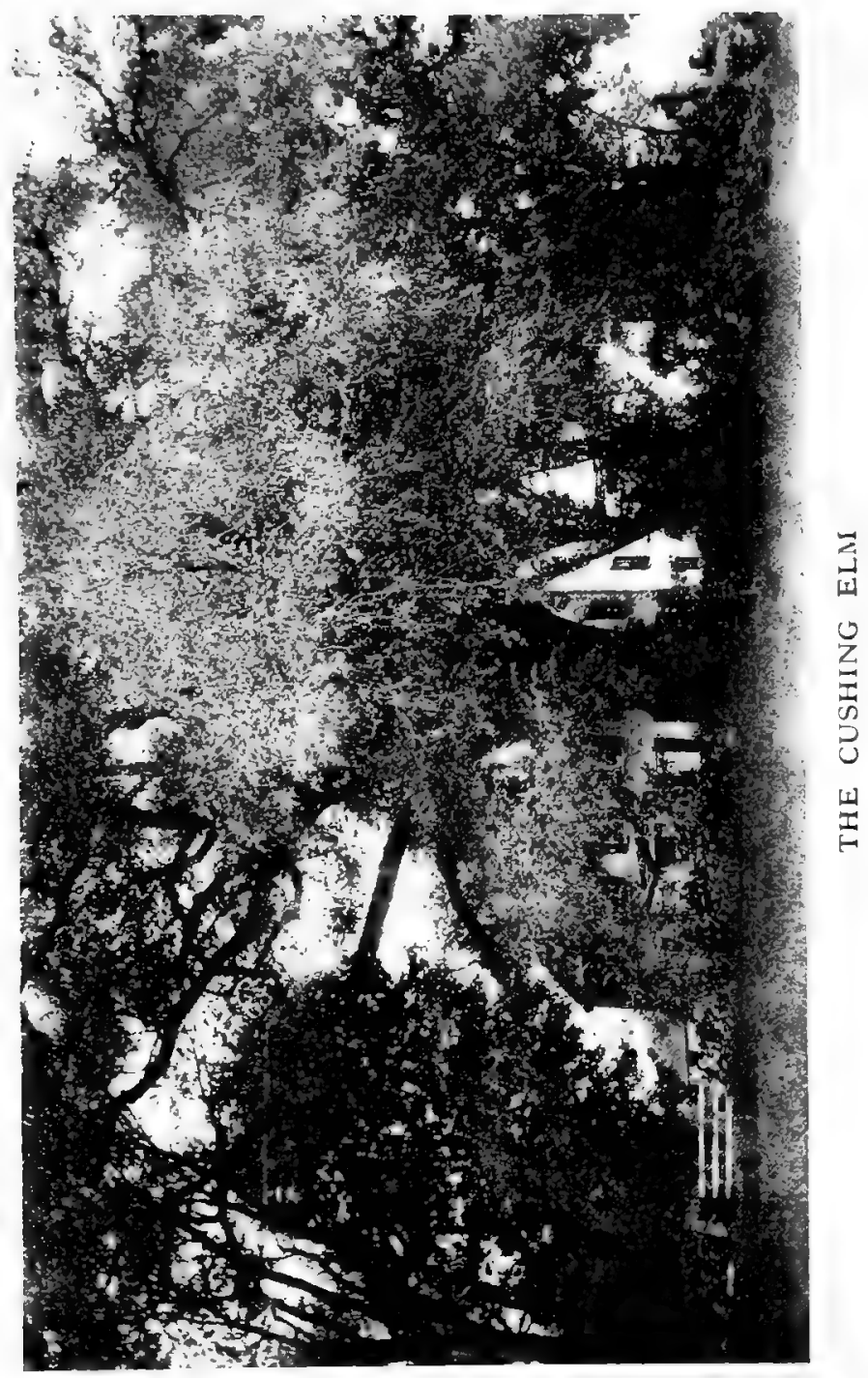



THE CUSHING ELM

tary movements in that vicinity during the "siege." Pastor John Brown was a Harvard graduate of the class of $174 \mathrm{I}$, and was ordained pastor of the second parish in Hingham Sept. 2, I747. He died in I79I at the age of sixty-seven years. ${ }^{1}$

The Hingham chapter of the Daughters of the American Revolution selected the inscription and placed it upon the tree a number of years ago. It commemorates one event, probably among a large number of others that were never recorded; for Hingham, during Revolutionary times, was the scene of more than ordinary activity, and the road on which the tree stands led directly to Cohasset and other coast towns further south. In I 775 the town maintained a reguIar garrison at Broad Cove, and was also one of the sea-coast towns called upon for assistance in protecting its neighbors from British attack. The terrible strain of longcontinued service began to be felt in 1776 , and in March of that year the town council appointed General LincoIn as its agent to

1 "Hist. of Hingham," published by the town, vol. 2, p. 94. 
THE HISTORIC TREES OF MASSACHUSETTS appeal to General Washington for relief. But as the historians of Hingham grimly point out, "the general seems to have had better use for his troops, both then and Iater. For on Sunday, March I7, General Howe evacuated Boston and General Putnam and General Ward entered the town. The next day General Heath with five regiments was ordered to New York, and with him went our townsmen under the two Captain Cushings." 1

The name of Cushing has been justly bestowed upon the "ancestraI eIm." The family came from Hingham in old England and settled in Hingham in New England as early as 1638 . Opposite this eIm tree, on the other side of the street, stands a fine old colonial house owned by Mr. Samuel Cushing whose ancestor, Stephen Cushing, planted the tree in 1729, three years before the birth of Washington. Stephen Cushing was the son of Peter Cushing, who built the house in 1678 . The tree originally stood

${ }^{1}$ Capts. Peter and Pyam Cushing, "History of Hingham," VoI. I, p. 294 .

$$
\text { [28] }
$$




\section{THE CUSHING ELM}

on the same side of the street and was several feet in height when transplanted to its present site.

At the age of nearly two hundred years it stands a marvel of strength and symmetry, a monument to the illustrious dead who went from Hingham to fight for their country, and the pride of their descendants who now hold it dear.

Some idea of its striking appearance may be had from the photograph. George B. Emerson gives an excellent word picture on the Cushing EIm in his work, "The Trees and Shrubs of Massachusetts." He says: "On the 25 of July, I839, I measured it in company of Mr. Wm. Oakes, a botanist of Ipswich. It was I3 feet in circumference at $4 \frac{1}{2}$ feet from the ground. At from Io to I2 feet eight Iarge branches are thrown out, which sweep upwards in a broad curve, making a noble round head sixty or seventy feet high. The immense roots which, beginning at three or four feet above the surface stand out like abutments in all directions, chiefly east and west, give an idea of per- 
manency and vast strength. The extreme spread of the limbs is 45 feet from the trunk, making the breadth of the head more than 90 feet. In the angle of one of the branches when I measured it, was growing a current bush, bearing ripe fruit."

So it stands to-day, in full vigor, and with considerably increased dimensions. Only one of the eight huge limbs has died out; the spread of the branches is over roo feet, and the circumference of the trunk, when the author measured it in the summer of 1916 , was $16 \frac{1}{2}$ feet, $4 \frac{1}{2}$ feet from the ground.

There are many other beautiful trees in Hingham, some of which might be called historic, though very little has been recorded concerning them. The elm in front of the town offices is 16 feet 2 inches in circumference at breast height, and has a height of 60 feet and a spread of 100 feet. The old buttonwood on Leavitt street is $14 \frac{1}{2}$ feet at $\mathbf{2} \frac{1}{2}$ feet from the ground, at which point the first limb is thrown out in an easterly direction; the height is 55 feet, and the spread of branches 80 feet. On [30] 


\section{THE CUSHING ELM}

Main street, South Hingham, on the lawn of Mr. Brown's estate, there is an old elm which was transplanted in $\mathbf{1 7 7 2 .}$ Its circumference at breast height is I I feet, 7 inches, its height 55 feet and the spread of its branches 80 feet. 
CHAPTER V

THE LAKEVILLE ELMS

The after-quiet — the caIm full fraught;

Thou too wilt silent stand, -

Silent as I, and lonesome as the Iand.

Herman Melville

TN a broad field near Middleboro, on the road to New Bedford, there are standing 1 at the present time two beautiful and towering "wine glass" elms. As you approach them from the north they give the impression of being so close together that the tips of the branches interlock; but upon entering the freld by way of the cart road leading in from the main highway they break upon the view as two separate columns, seventy-five feet apart, lifting their heads upward into the sky. Each is slender and graceful, not possessed of great age, but singularly beautiful in its isolation from everything save field and sky and distant woods.

[32] 


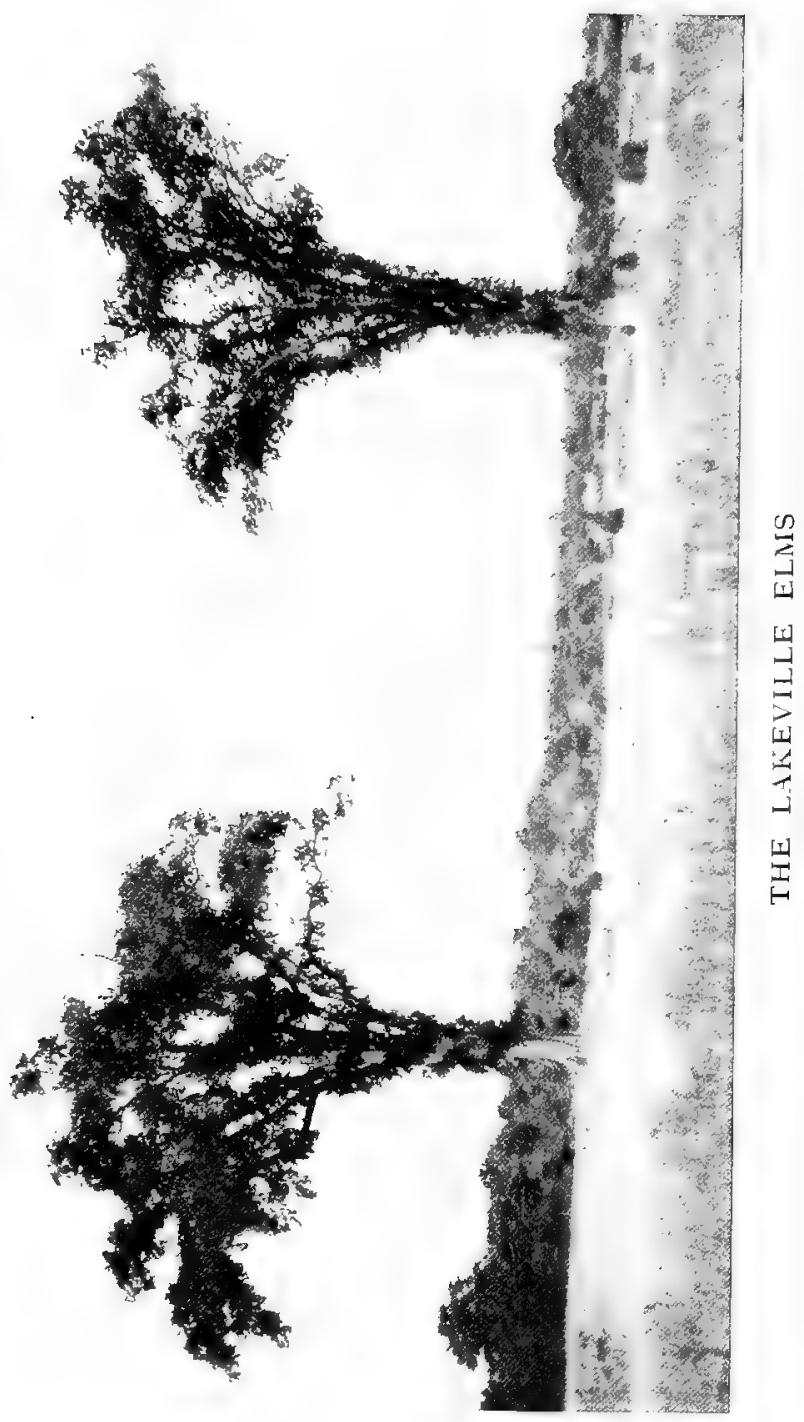


, 
They are considered historic in that they stand in the middle of what was once a training-freld, where the soldiers of this community were mustered for service in the Civil War.

The men who enlisted from Middleboro and its environs served their country with honor and distinction, notably among the first battles of the war. The towering elms, ever a frtting memorial to the brave, stand here as if rapt in silent reflection, garlanded almost to the ground with green leaves, overlooking the place where some of the boys in blue prepared themselves for the great crisis.

The Iarger tree of the two has a height of 60 feet, a spread of $6_{5}$ feet and a circumference, at breast height, of $8 \frac{1}{2}$ feet. The smaller tree is 60 feet in height, 50 feet in spread and 7 feet in circumference. 
CHAPTER VI

ISLAND GROVE

Lift again the stately emblem on the Bay State's rusted shield, Give to northern winds the Pine Tree on our banner's tattered field.

Wbittier

THIS beautiful stand of white pine trees at Abington has come to be 1 known Iocally as Island Grove, but generally as Abolition Grove, and is often pointed out to the stranger within our midst as "the place where the Civil War began." Here, in the open air, sheltered only by the whispering pines, great men, and women, too, stood and delivered speeches in the cause of abolition comparable to any that were delivered in the celebrated halls of our great cities, and that produced an effect comparable to John Brown's raid or Uncle Tom's Cabin.

Webster, "a man who loved mountains, and great trees, wide horizons, the ocean, the western plains, and the great monuments [34] 


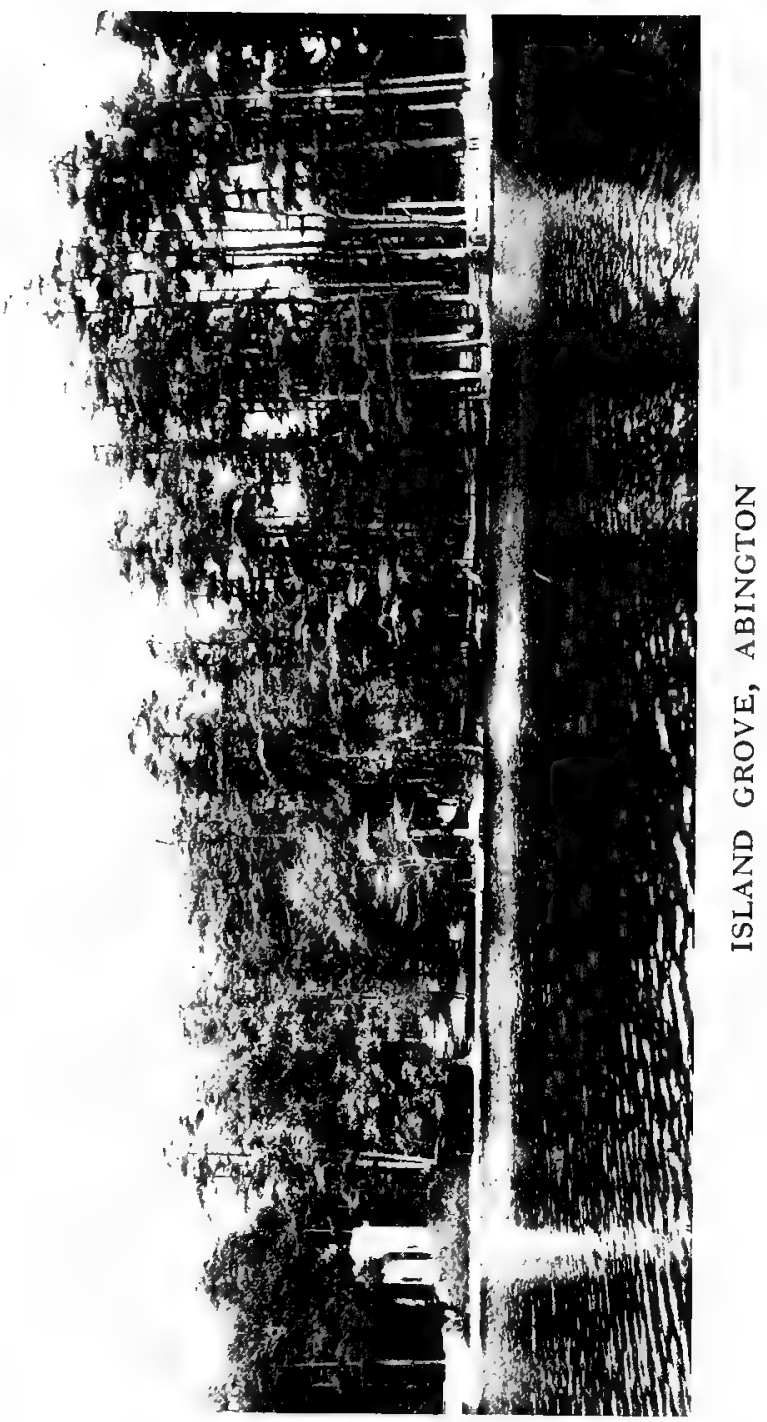





\section{ISLAND GROVE}

of literature and art," 1 spoke in this historic place; and Garrison, who for many years "toiled o'er his types one poor unlearned young man," was beard by the worthy people of Abington and the surrounding towns beneath these same white pines. Here on the first of August, 1854, he said, when speaking on the subject of West Indian Emancipation, - "The great event which we celcbrate to-day, shows that slavery can only be overthrown by adherence to principle." 2

The full list of those who spoke here includes some of the greatest minds of the Civil War period. Most of the speeches were never preserved, and the historian must search through many sources to find even a record of the dates on which they were delivered.

A huge boulder within the grove marks the spot where the orators were wont to stand when they spoke; and upon this boulder a large copper plate bears the following inscription:

1 Lodge, "Life of Webster," p. 353.

2 From the Selectmen's Annual Report, 1854. 
THE HISTORIC TREES OF MASSACHUSETTS

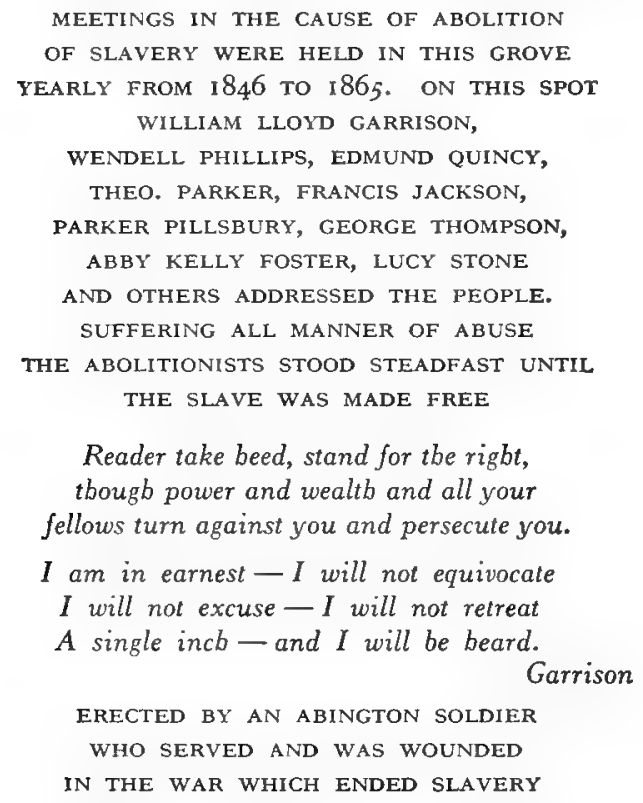

Reader take beed, stand for the rigbt, thougb power and wealtb and all your fellows turn against you and persecute you.

$I$ am in earnest $-I$ will not equivocate $I$ will not excuse - I will not retreat A single incb - and $I$ will be beard. Garrison

ERECTED BY AN ABINGTON SOLDIER WHO SERVED AND WAS WOUNDED IN THE WAR WHICH ENDED SLAVERY

The Abington soldier who presented this memorial to the town was Moses N. Arnold. Among the invited guests who were present and participated in the exercises were: Judges Robert O. Harris and G. W. Kelley, Hon. A. E. Pillsbury, Francis Garrison, Wm. Lloyd Garrison, (Mrs.) Helen B. Coggeshall and Henry B. Blackwell.

To the abolitionists belongs the distinction of rendering the grove historic. In addition, [36] 
ISLAND GROVE

the people of Abington have increased its fame by gathering beneath its shade for the celebration of all anniversaries commemorating the founding of their town, as well as for other noted events.

In 1862 a celebration in commemoration of the incorporation of the town was attended by the Governor and members of the State departments, and by some of the veterans of the war of 1812. The opening words of Governor Andrew's speech are worthy of quotation here:

"Well have the men and women of Massachusetts met and performed the solemn task of dreadful war. More than forty thousand of her sons - bravest and best - have been poured from her teeming lap. Fighting today they stand, wherever floats our country's starry banner, on land or sea."

This event was followed, in 1865 , by a reception to the returned soldiers and sailors from Abington and "the day was ushered in and closed by the ringing of bells and the firing of cannon." 1

1 From the Selectmen's Annual Report $186_{5}$. 
THE HISTORIC TREES OF MASSACHUSETTS

The most recent celebration held at Island Grove was that of the two-hundredth anniversary of the founding of the town, June I0, I9I2. On this date the beautiful bridge and gateway leading to the grove were dedicated to the public use. 


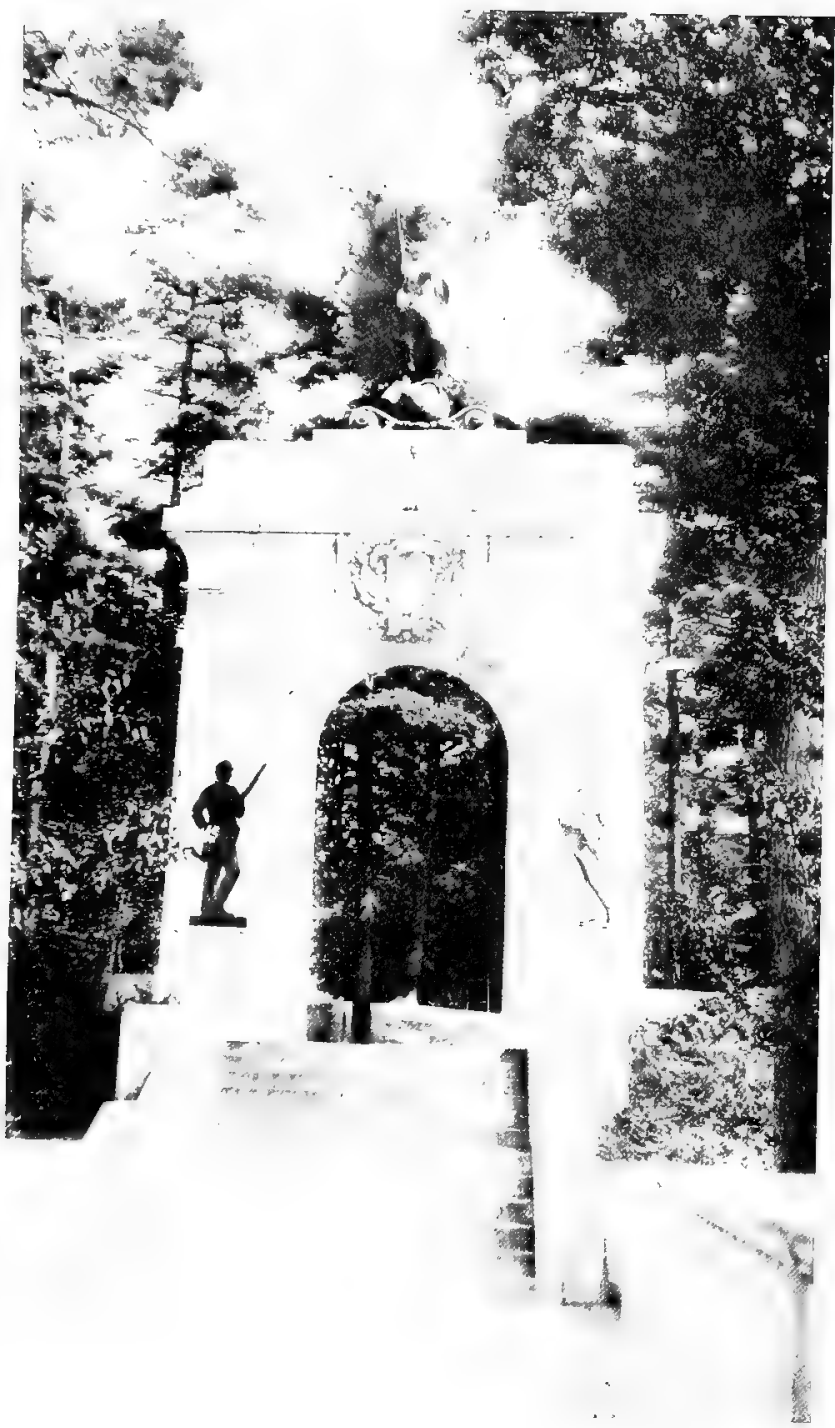

THE ENTRANCE TO ISLAND GROVE 


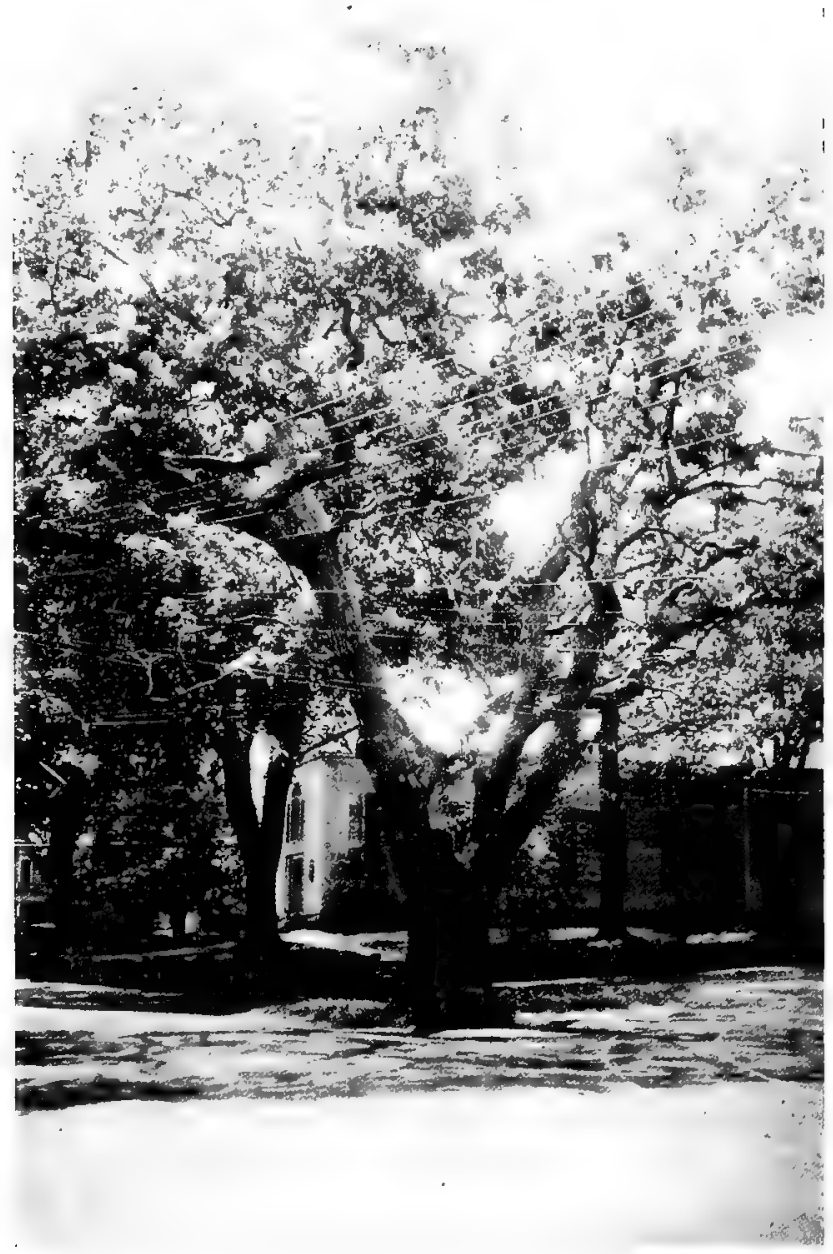

THE ELIOT OAK 
ELIOT OAK AND OTHER TREES OF SOUTH NATICK

For underneath thy shade, in days remote, Seated like Abraham at eventide

Beneath the oaks of Mamre, the unknown

Apostle of the Indians, Eliot, wrote

His Bible in a Ianguage that hath died

And is forgotten, save by thee alone.

Longfellow

TOHN ELIOT, justly styled Apostle to the Indians, and founder of Natick, both in church and state, first gathered the red men together "from their scattered kind of life into civil society" within the shades of the forest, and preached to them beneath a white oak, now a mighty tree, universally known as the Eliot Oak.

While established as a teacher of the church in Roxbury, about 1632, Eliot was "moved to compassion for the ignorant and depraved state of the Indians," and resolved to devote a part of his time to their instruction. He undertook the almost hopeIess task of learning their language and 
found that the length and harshness of their words were almost overwhelming. Cotton Mather says that men would stand aghast at some of the instances - sighting as an example the expression "our lusts" which requires a word of thirty-two letters in the Indian language. "Behold, ye Americans," says he, "the greatest honor that ever ye were partakers of! The Bible was printed here at our Cambridge; and is the only Bible that ever was printed in all America, from the very foundations of the world. The whole translation he writ with but one pen, which pen had it not been lost, would have certainly deserved a richer case than was bestowed upon that pen with which Holland writ his translation of Plutarch." 1

In loyalty to the man who did so much for them, the Indians built the first meetinghouse near the spot where their apostle was accustomed to speak to them. The white oak stood at its easterly end. At the westerly end there was a red oak of vast proportions. In 1850 when this tree was 1 Mather's "Magnalia," B III, p. I97.

[40] 
ELIOT OAK AND OTHER TREES OF SOUTH NATICK cut down it measured 17 feet in circumference at 2 feet from the ground. ${ }^{1}$ The Eliot Church (Unitarian) in South Natick now marks the spot where stood the Indian meeting-house.

Several interesting stories have come down through the years concerning Eliot's first efforts among the red men. There is no record to prove conclusively whether they originated at the foot of the oak tree, or within the little chapel, but they carry with them a background of spreading branches, green leaves and acorns; and we can imagine the venerable preacher, Bible in hand, his back to the tree trunk, and Indians seated in groups upon the ground in the midst of the forest.

"While engaged in the translation of his Indian Bible, Eliot came upon the following passage in Judges v, 28: "The mother of Sisera looked out at the window and cried through the lattice.' Not knowing an Indian word to signify lattice, he applied to several of the natives, and endeavored to describe

1 Bacon, "Hist. of Natick," p. 12. 
to them what a lattice resembled. He described it as framework, netting, wicker, or whatever occurred to him as illustrative, when they gave him a long, barbarous and unpronounceable word, as are most of the words in their language. Some years Iater, when he had learned their dialect more correctly he is said to have Iaughed outright, upon finding that the Indians had given him the true term for 'eel pot.' 'The mother of Sisera looked out at the window and cried through the eel pot!"' 1

"One of these sons of the forest is said to have discovered a more appropriate" emblem of the Trinity than even the triangle itself. The missionary had been lecturing on this sublime and incomprehensible mystery, when one of his red auditors, after a long and thoughtful pause, thus addressed him, 'I believe, Mr. Minister, I understand you. The Trinity is just like water and ice and snow. The water is one, the ice is another, and the snow is another, and yet they are all water.", 2

$$
[42]^{1} \text { Bigelow, p. 84. 2 Bigelow, p. } 85 .
$$


ELIOT OAK AND OTHER TREES OF SOUTH NATICK

The high esteem in which Eliot was held by the Praying Indians passed on as a heritage to some of the ministers who were called to Natick at a later time. In 1722 a deputation of Indians came to the Rev. Mr. Peabody's house bearing two elms on their shoulders. These they presented to their minister and desired permission to set them out in front of his door as "trees of friendship." They flourished for ninety years when one was struck by lightning, and the other declined rapidly and was removed. They measured twenty-one feet at one foot from the ground, and thirteen feet at the smallest part of the trunk. ${ }^{1}$ In 1753 a like request was made by the Indians of their minister, Mr. Badger, and the same ceremony took place. The Hon. John Welles observes, (1826), "These trees are now in full vigor, having been set out seventy-three years. They are about fifteen feet in circumference near the ground, and have given in circumference nearly $I \frac{1}{2}$ inches in growth a year." The elm now pointed out as the remaining

1 Bigelow, p. I2, Bacon, Chap. 10.

$$
\text { [43] }
$$


THE HISTORIC TREES OF MASSACHUSETTS

"tree of friendship" in front of the Badger house measures $10 \frac{1}{2}$ feet in circumference at breast height. There is, however, an elm near the road, to which Welles may have referred, that is $13 \frac{\mathbf{1}}{2}$ feet in circumference at breast height, and a little over is feet near the ground. The tree in the yard is in direct line with the stump of a Iarger tree claimed to have been its companion.

Several other trees have become identified with the history of the town. An elm, described by Bacon as the finest of all blew down only a few years ago. The spread of its branches was over one hundred feet. The elm which stands on the margin of the Charles River, not far from Eliot's monument, is one of the most magnificent specimens of its kind to be seen anywhere. The curves of its powerful branches, were it situated on higher ground, would be visible for miles. Other characteristics are its apparent health and strength.

A very beautiful elm may be seen about a quarter of a mile further up the street. Under this tree Washington stood and con[44] 
ELIOT OAK AND OTHER TREES OF SOUTH NATICK gratulated Major Hesekiah Broad for his services in behalf of the Colonies. The circumference is I I feet, 8 inches, the height 65 feet, and the spread 85 feet.

On the rising ground to the northwest stands the "Carver Hill Chestnut," a huge and towering tree, the last survivor of a chestnut ridge that made its owners wealthy. Mention may also be made of the Hartwell Oak on Pleasant Street, noted for its remarkable shape and for the wide spread of its branches; and of a very old and beautiful oak near the road on the way to Wellesley from South Natick. The latter is also claimed to mark the site of one of Washington's resting places, and is $15 \frac{1}{2}$ feet in circumference.

Among all this interesting collection the Eliot Oak holds the first place in the minds of travelers to the Iocality of South Natick. It is not so large as might be expected from its age, and like Holmes's old eIm of Rhode Island, must tremble sometimes as the tape is applied to its trunk. But the white oak is seldom conspicuous for rapid growth, and we are not in any way disappointed with the

[45] 
THE HISTORIC TREES OF MASSACHUSETTS

dimensions of this one; its age is plainly written upon its noble frame. The circumference of the trunk is is feet, 2 inches, the height is 6I feet, and the spread of the branches is ioo feet.

$[46]$ 


\section{CHAPTER VIII}

\section{AVERY OAK AND OTHER TREES OF DEDHAM}

That old familiar tree,

Whose glory and renown

Are spread o'er land and sea -

And wouldst thou hew it down?

Woodman, forbear thy stroke!

Cut not its earth-bound ties;

Oh, spare that aged oak

Now towering to the skies!

T the days when navies were composed entirely of wooden ships, and America

1 was known as a great source of shipbuilding materials, the white oak was one of the most sought-after of all our New England trees; and in spite of the great quantity of virgin timber that still remained among the colonies at that time, the price was unusually good for individual trees whose size and shape made them suitable for ship-construction.

If aIl the stately white oaks which were built into the sturdy frame of "Old Ironsides" could be accounted for, we would have a list of historic trees whose adventures would fill a thrilling volume. But history 


\section{THE HISTORIC TREES OF MASSACHUSETTS}

is silent, except in a few instances, concerning where the trees were bought whose trunks composed the old-time frigates. A white oak near Danvers, known as "King George's Whipping Post," because condemned persons were often tied to a ring in its trunk and flogged according to the seriousness of the crime, was purchased for use in the construction of the frigate Essex. It is said that the iron ring was actually found in the trunk of the tree when the timbers were hewed. ${ }^{1}$

The oldest white oak in Dedham bears the distinction of having once been selected

\section{THE SALEM FRIGATE}

TAKE NOTICE

1 Ye Sons of Freedom! all true lovers of the Liberty of your Country! step forth, and give your assistance in building the Frigate, to oppose French insolence and piracy. Let every man in possession of a White Oak Tree, be ambitious to be foremost in hurrying down the timber to Salem, and fill the complement wanting, where the noble structure is to be fabricated, to maintain your rights upon the Seas, and make the name of America respected among the nations of the world. Your Iargest and longest trees are wanted, and the arms of them for Knees and Rifing Timber. Four trees are wanted for the Keel, which all together will measure $\mathrm{x} 46$ feet in Iength, and hew 16 inches square. Please to call on the Subscriber, who wants to make contracts for large or small quantities, as may suit best, and will pay the READY CASH.

Salem, Nov. 23, 1798

ENOS BRIGGS

[48] 


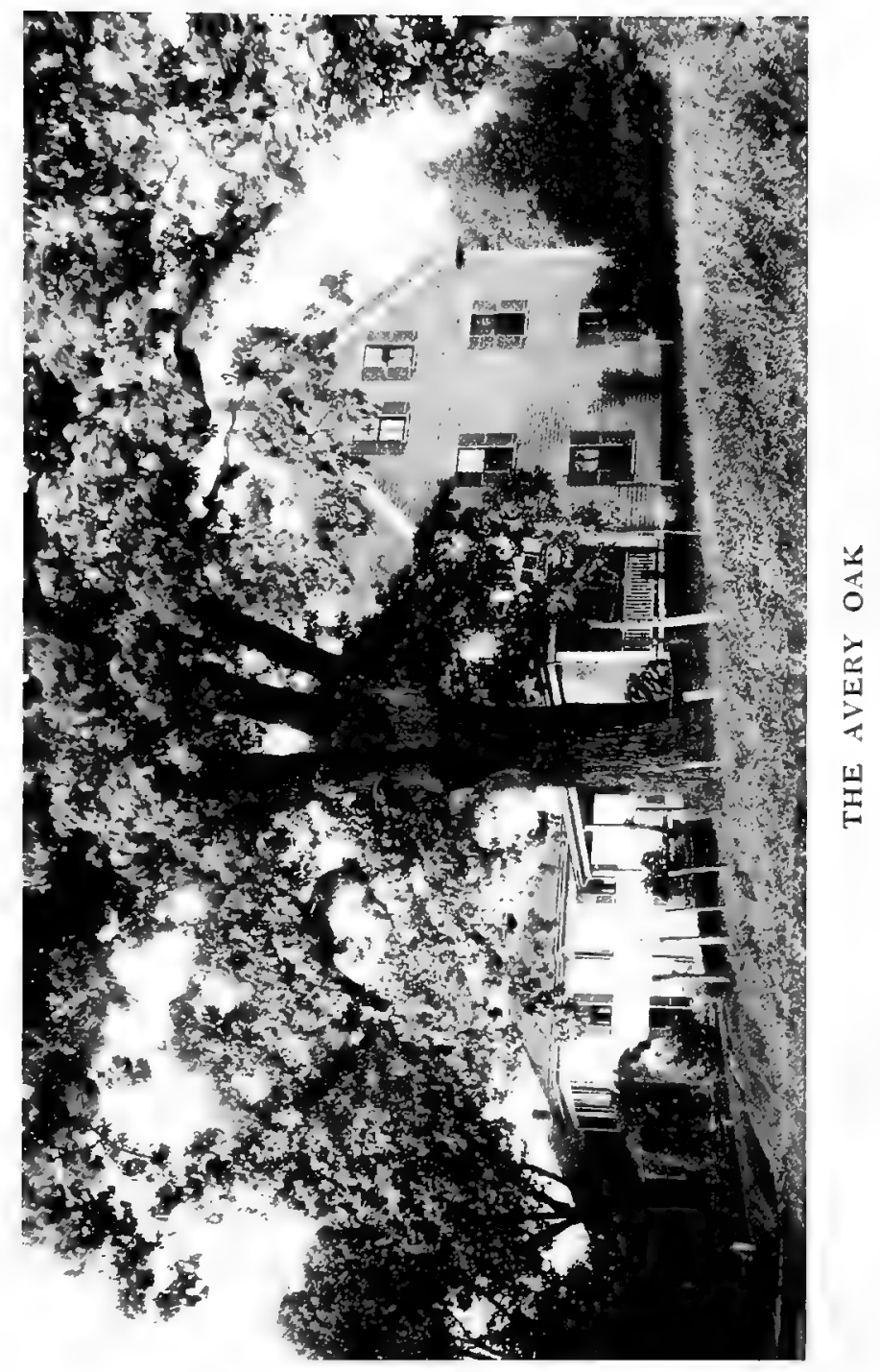




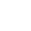


AVERY OAK AND OTHER TREES OF DEDHAM

as suitable material for the celebrated and much honored frigate that still lies at anchor off Charlestown - Old Ironsides. The amount offered was seventy dollars. The offer was refused because the owner's wife, Mrs. William Avery, who greatly admired the tree, prevailed upon her husband to spare it.

This took place in the eighteenth century, and the Avery oak is still with us, gnarled but vigorous. Along the whole length of the trunk, and well into the main branch, may be seen a deep furrow, ten inches wide or more near the ground, evidently caused by lightning. A healthy cambium, and some surgical assistance, have enabled the tree to practically outgrow the adversities of former years.

A record for the year 1847 gives the size as sixteen feet in circumference near the ground. ${ }^{1}$ The present circumference at one foot above the ground is twenty-three feet, five inches, and the circumference at breast height is now sixteen feet, nine inches. To these figures may be added the height, which is

1 Mann, "Annals of Dedham," p. 125. 
sixty-eight feet, and the spread of branches, which is ninety-three feet.

The tree is older than the town, and is claimed on the basis of tradition to mark the site of the first religious meeting ever held in Dedham. Dr. William Avery, for whom the tree was named, caused a chair to be made from some of the branches which blew off, and as an accompanying memento, a table, constructed of timbers from the old Avery house. The chair and table he presented to the Dedham Historical Society. The tree also has the distinction of being adopted as a model for the town seal. In I $886 \mathrm{Mr}$. Joseph H. Clark presented the tree, and the ground on which it stands, to the Historical Society, and it is still owned and cared for by that organization. The location is on East street, a short distance from the point of its intersection with Eastern avenue, and near the Fairbanks house.

There seems to be no recorded history of the faithful old white oak that stands within the village pound on High street. Surely this oak with its great age could $[50]$ 
AVERY OAK AND OTHER TREES OF DEDHAM relate a good Pickwickian story were it endowed with the gift of tongues. At any event it is considered historic and has been decorated with a legend -

$$
\begin{gathered}
\text { THIS POUND BUILT } \\
\text { ABOUT I7OO } \\
\text { CIRCUMFERENCE OF OAK } \\
\text { I } 9 \text { FEET }
\end{gathered}
$$

The circumference of this tree at breast height is 16 feet, 3 inches; the height is 45 feet, and the spread of the branches 60 feet.

Three English elms greatly esteemed by the people of Dedham are still standing on Court street. They are now declining but retain much of their original beauty. The largest is is feet, io inches in circumference. The other two have a girth of 13 feet. The famous "Wart Tree," also an English elm, succumbed and was removed in 1908. 
CHAPTER IX

THE HOLLISTON ELMS

Be it ours to meditate,

In these calm shades, thy milder majesty.

Bryant

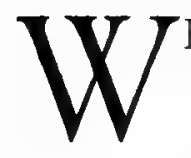

HEN the Honorable Levi Lincoln was Governor of Massachusetts (1825-34) he was accustomed to drive, at certain intervals, from the capital in Boston to his home in Worcester by way of the road leading through Natick, Sherborn and Holliston. He was a lover of nature, and elected to travel where his itinerary brought him in closest communion with his favorite trees and hills. Governor Bullock, speaking before the Worcester Agricultural Society, of which Mr. Lincoln was president during the Iater period of his life, said of him, that "trees, above all things, Governor Lincoln believed in and admired."

Chief among the elms which attracted [52] 
his attention during the years of his administration of the State government were the two trees towering, then as now, close to the highway near East Holliston. It was the Governor's habit to request his driver to stop where the trees might be viewed to the best advantage, and there, for a few silent moments, His Excellency would absorb the influence of their omnipresence; he would then drive on with uncovered head, deeming that such manifestations of the work of the Great Craftsman deserved the respect and admiration of all men, whatever their rank and station in life.

Governor Lincoln was not the only high public official on whom the Holliston Elms, even at that early date, had made their impression. The great Washington had passed this way in 1789 , and had rested beneath their shade. The Father of His Country was far from demonstrative, but it is known that he sincerely revered the great monuments of nature, and, either by chance or design, selected his ground, when a halt was called, with the instinct of a true 
THE HISTORIC TREES OF MASSACHUSETTS

naturalist - at least if we are to judge from the number of times he is reported to have rested under great trees.

The elms at Holliston were planted about the year 1747. They may have been six or seven feet in circumference during Washington's time, and were probably approaching the size of second-class elms when Governor Lincoln first noticed them. They seem to have escaped the attention of those who would have given them a place in literature - as suggested in the following newspaper clipping from the Framingham Tribune in possession of CoI. G. A. Flagg of Holliston. Editor of the Tribune:

There are two elm trees in Holliston which should be classed among the big trees of the state.

I have seen no mention of them in any account of the famous trees of Massachusetts. They are situated on the Main street between Holliston and East Holliston, in front of what is known as the Col. Whiting place, now owned by Mr. Flagg. We made an accurate measurement of them to-day. The smallest measures one foot from the ground, nineteen feet in circumference, four feet from the ground, sixteen feet in circumference.

The shape of this tree is something remarkable. The trunk is almost square, having four sides. Three of the sides measure about five feet each.

The larger of the two trees measures, one foot from the ground, twenty-four feet, the large roots spreading outward. Four feet from the ground it measures seventeen feet in circumference. The trees appear perfectly sound, and the branches

[54] 


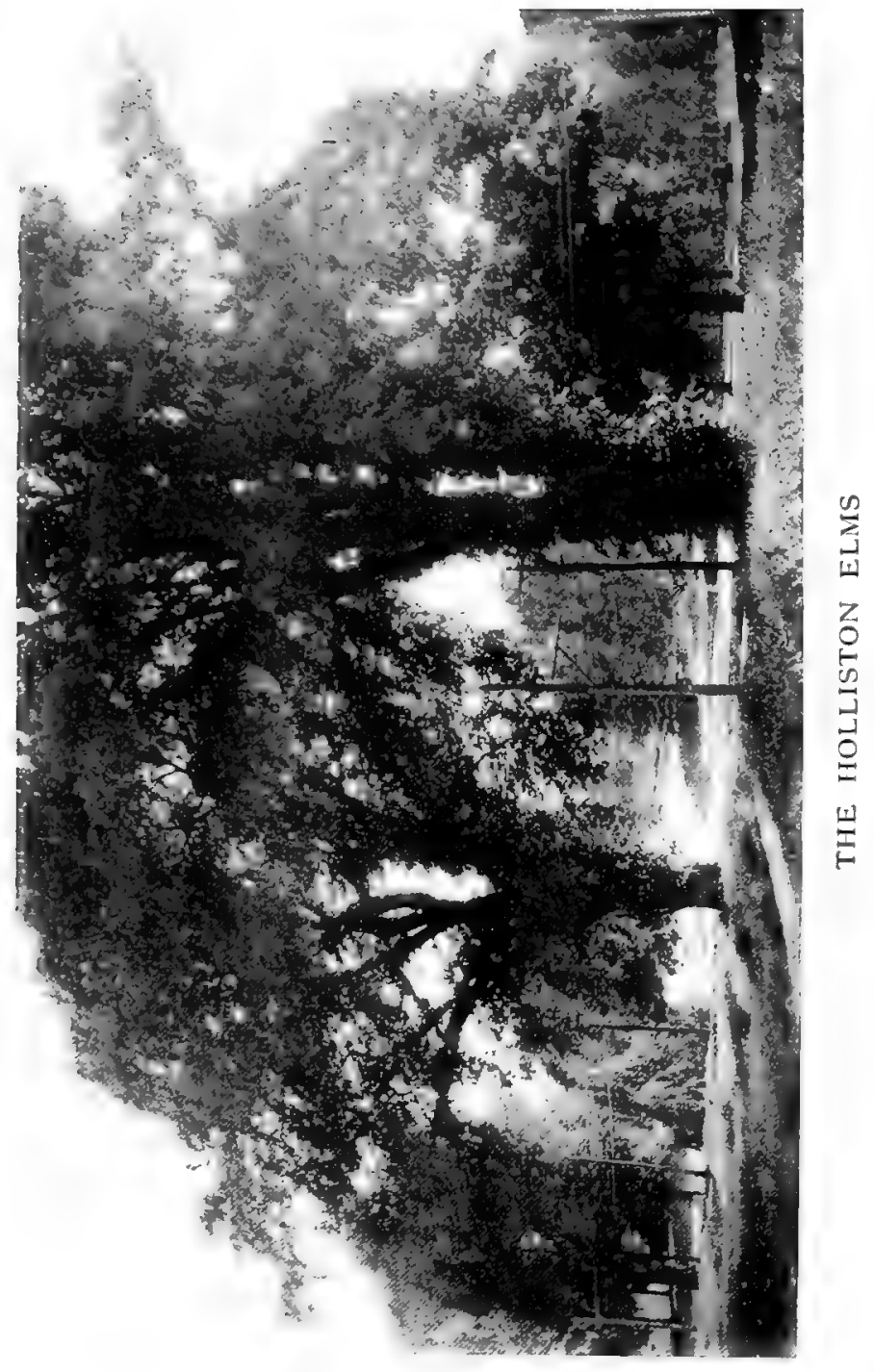




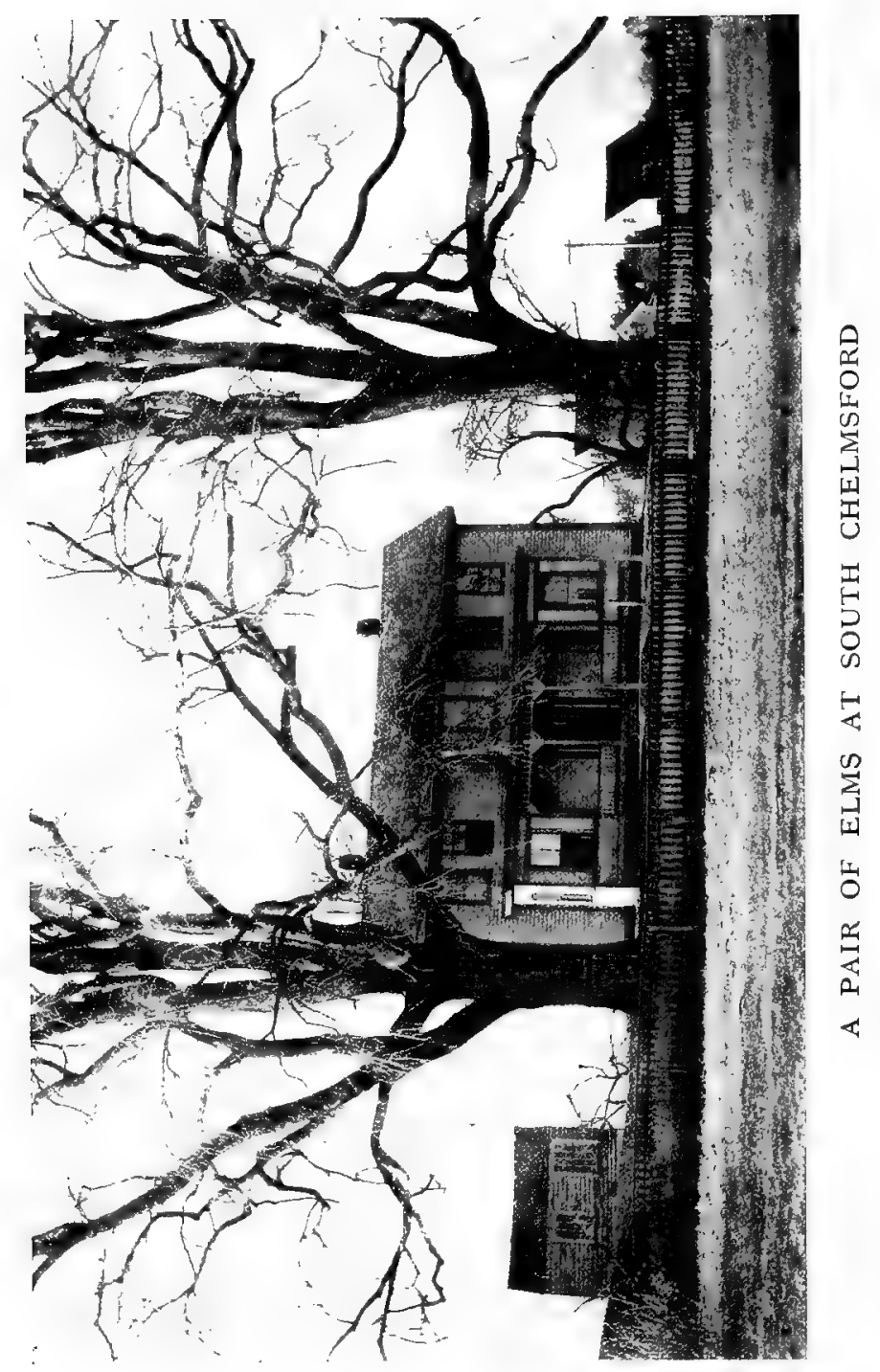




\section{THE HOLLISTON ELMS}

not spreading outward, or overhanging, but towering to a height of one hundred feet.

I know of no trees in this section that will compare with them.

These magnificent elms were planted by Aaron Phipps during his apprenticeship to Dea. James Russell (blacksmith) between 1747 and 175I (see Morse's history of Sherborn and Holliston).

It is said Washington rested under these trees on his return from Boston in 1789 . He spent the night in Uxbridge, and, Holliston being halfway between Boston and Uxbridge, he very likely stopped here to dinner.

Yours truly,

Thomas A. Dickinson

The larger of the two trees is quite as "remarkable" in its way as the smaller, and is certainly more "magnificent." It is one of those elms whose habit it is to cover its trunk with small twigs, and appears, in summer, like a fountain of leaves rising out of the earth. Unquestionably no pair of elms in Massachusetts can surpass these in size and grandeur; none give greater hope of preserving their beauty far into the future. The author's measurements are the following: for the Iarger tree the circumference at breast height is $18 \frac{1}{2}$ feet, the height is 92 feet, and the spread 80 feet. For the smaller the circumference is $16 \frac{1}{2}$ feet, the height 85 feet, and the spread 85 feet.

By way of comparison, a pair of elms in 
THE HISTORIC TREES OF MASSACHUSETTS

the town of South Chelmsford, another in the town of Lincoln may be briefly referred to. For, in some respects, the first named are more beautiful as a group than even the Holliston elms, while the Iatter have that peculiar interest and charm that arise from great age. The South Chelmsford elms are on the W. R. Winning farm not far from Carlisle Station. Each is 14 feet in circumference, and the combined spread of the branches is I 25 feet. They are always conspicuous for the number of birds that nest in their branches, chiefly orioles and vireos. The elms in Lincoln stand directly in front of the oldest house in the town about seventyfrve yards from the State road leading from Concord to Boston, and approximately two miles east from Concord. They are about is feet in circumference, and are beginning to decline. The branches have a highly muscular appearance but have suffered somewhat from insect pests.

$$
[56]
$$




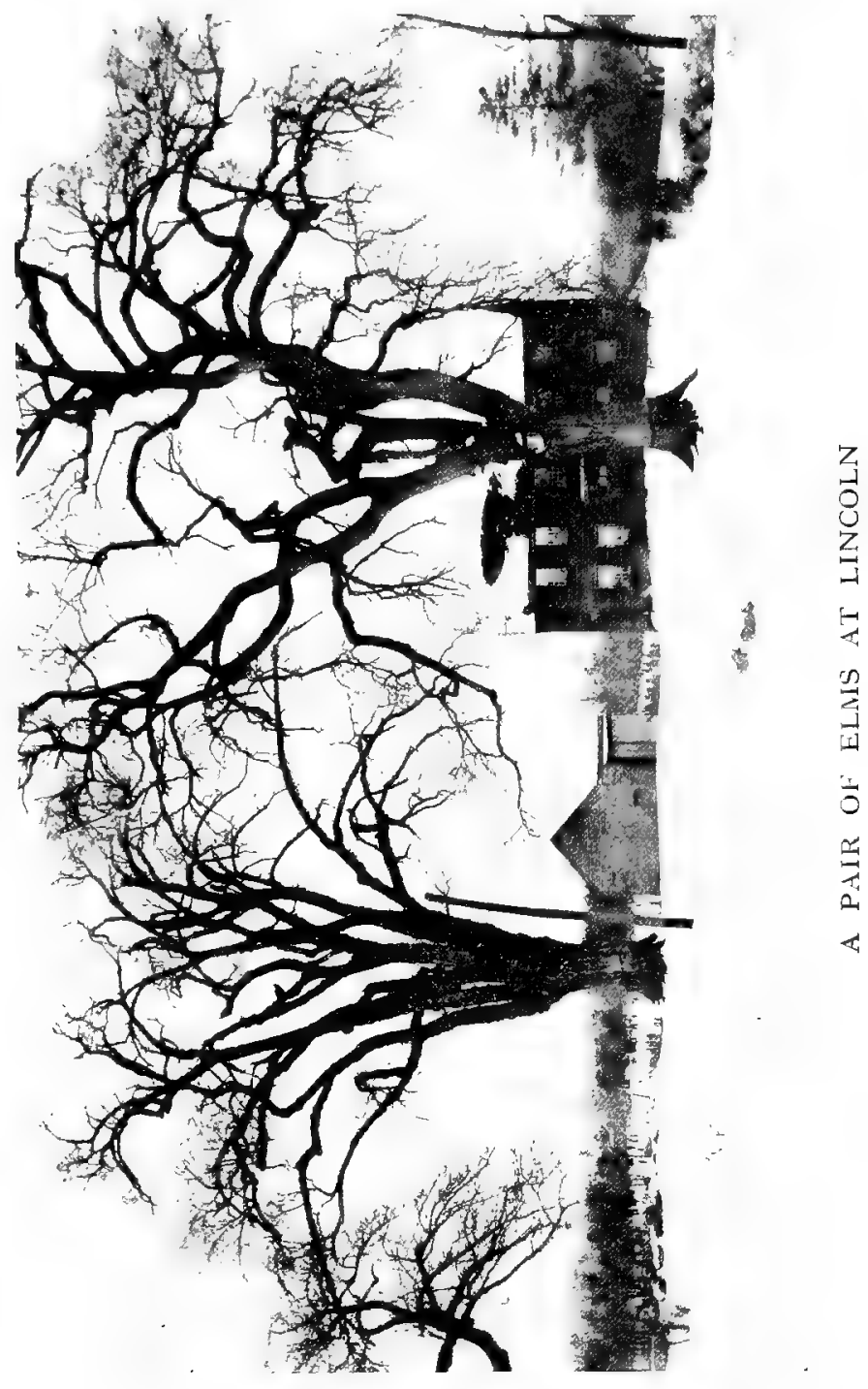




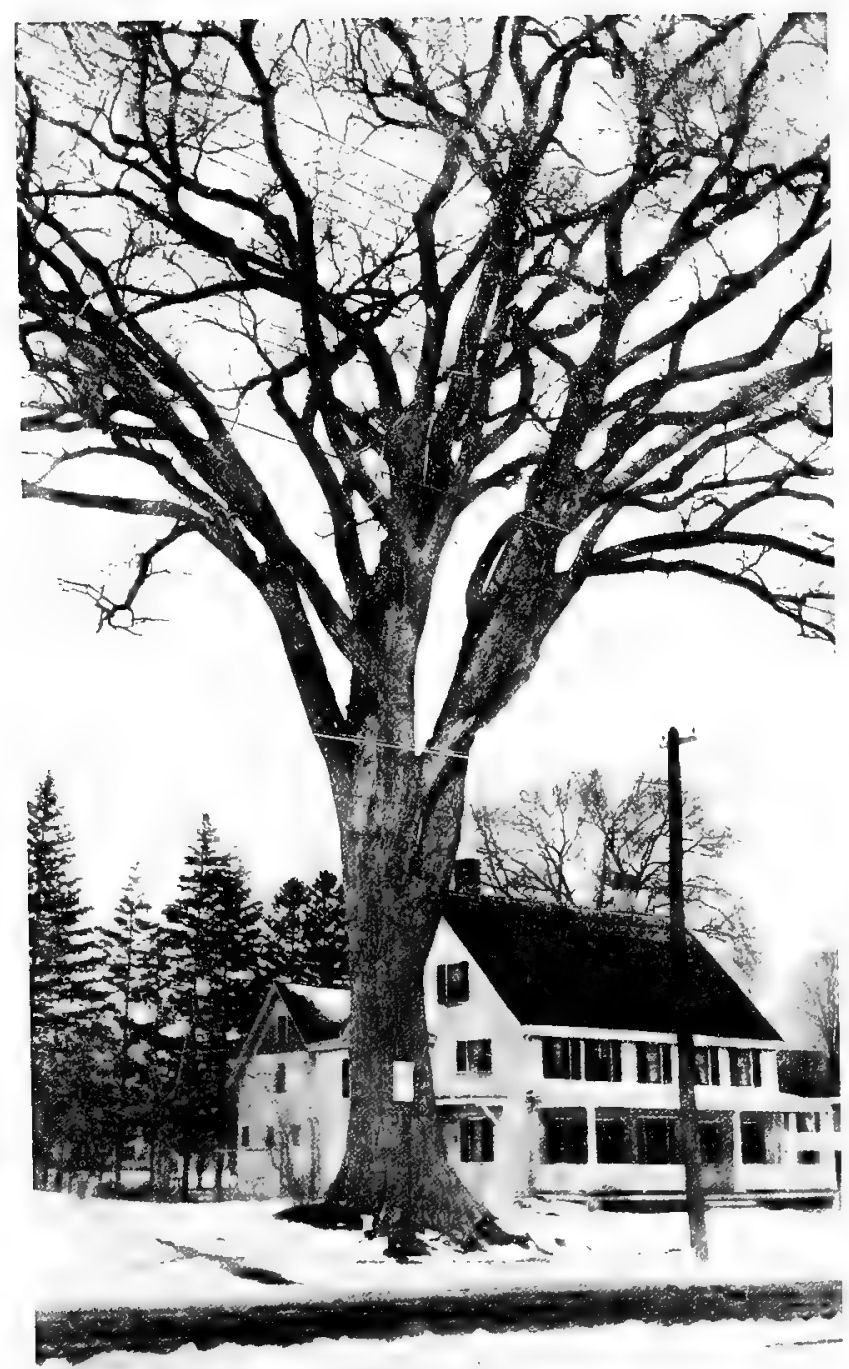

THE ROBY ELM 


\section{CHAPTER $\mathrm{X}$}

\section{THE ROBY ELM}

Over our heads the branches made

A canopy of woven shade.

Cbarles Henry Luders

HE Roby Elm, so named from Parson
Roby who planted it about the year
I770, stands on Main street in the town of Saugus. ${ }^{1}$ Its circumference is I5 feet, 2 inches, spread roo feet, and height 75 feet. The trunk is of unusual length, being about 30 feet, and numerous large branches sweep upwards for at least twenty feet more before spreading to form the crown.

It is related that the parson selected and dug this tree with great care, placing it in his house, still a fine old residence and one of the landmarks of Saugus, where he

1 The reader will be interested in comparing this tree with the Mariboro Elm described in Chap. XV both as to its form and the events with which it is associated. 
THE HISTORIC TREES OF MASSACHUSETTS

kept it until the following morning, and planted it in a suitable spot in his yard.

The parsonage was a favorite rendezvous for the Patriots of this locality, and $\mathrm{Mr}$. Roby was a well-known personage among those with whom he Iabored for more than half a century. He was evidently one of those ministers who believed it his duty to frght as weIl as to preach, and had the honor of being presented to Washington at Newhall Tavern in East Saugus, where the General stopped on his way towards Boston along the Newbury turnpike road.

Parson Roby died in the eighty-third year of his age, and the fifty-third of his ministry here, in 1803 . He was stricken while preaching to his people.

As a matter of passing interest it may be said that in this old town there is a beautiful specimen of the black walnut, an older tree, supposedly, than the Roby EIm, concerning which the author of "Our Trees" (of Essex County) ${ }^{1}$ says, "It is quite among the possibilities that Cotton Mather could have

$\left[5^{8}\right]$

1 John Robinson. 


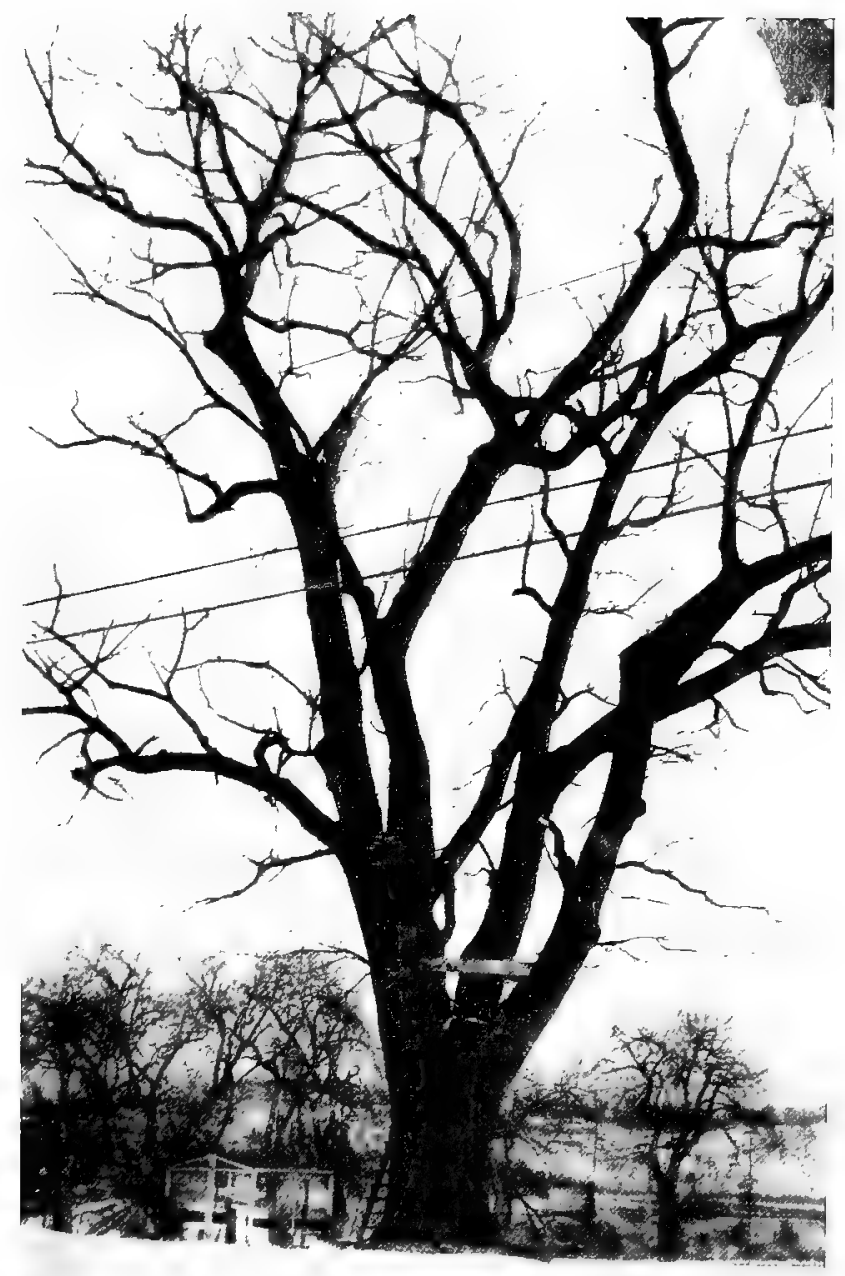

THE CHEEVER WALNUT 

stopped to rest beneath the shade of the 'Cheever Walnut' on his way on horseback, from Boston, to witness the witchcraft executions on Gallows Hill in Salem in 1692." It stands on Center street, and measures $13 \frac{1}{2}$ feet in circumference, $6_{5}$ feet in height, and 87 feet in the spread of its branches. 


\section{CHAPTER XI}

\section{THE BOXFORD ELM}

\section{'Twas my forefather's hand}

That placed it near his cot.

George Pope Morris

\section{A. MONG the famous Indian characters whose names and deeds are indelibly written upon the pages of New Eng-} land history, was an old "sagamore" named Masconomet of Agawam. The territory over which he held sway was bounded on the north by the Merrimac River, on the west by Naumkeag, generally known as Massachusetts, which means, - "at or near the great hill," and on the east and south by the Atlantic Ocean. From this old sagamore, Governor John Winthrop procured, in 1638 , a deed of the whole tract of Iand then included in the town of Ipswich, which also included the present town of Boxford. Masconomet died about the year $16_{5} 8$, and was weIl known as a friend of the white men.

[6o] 


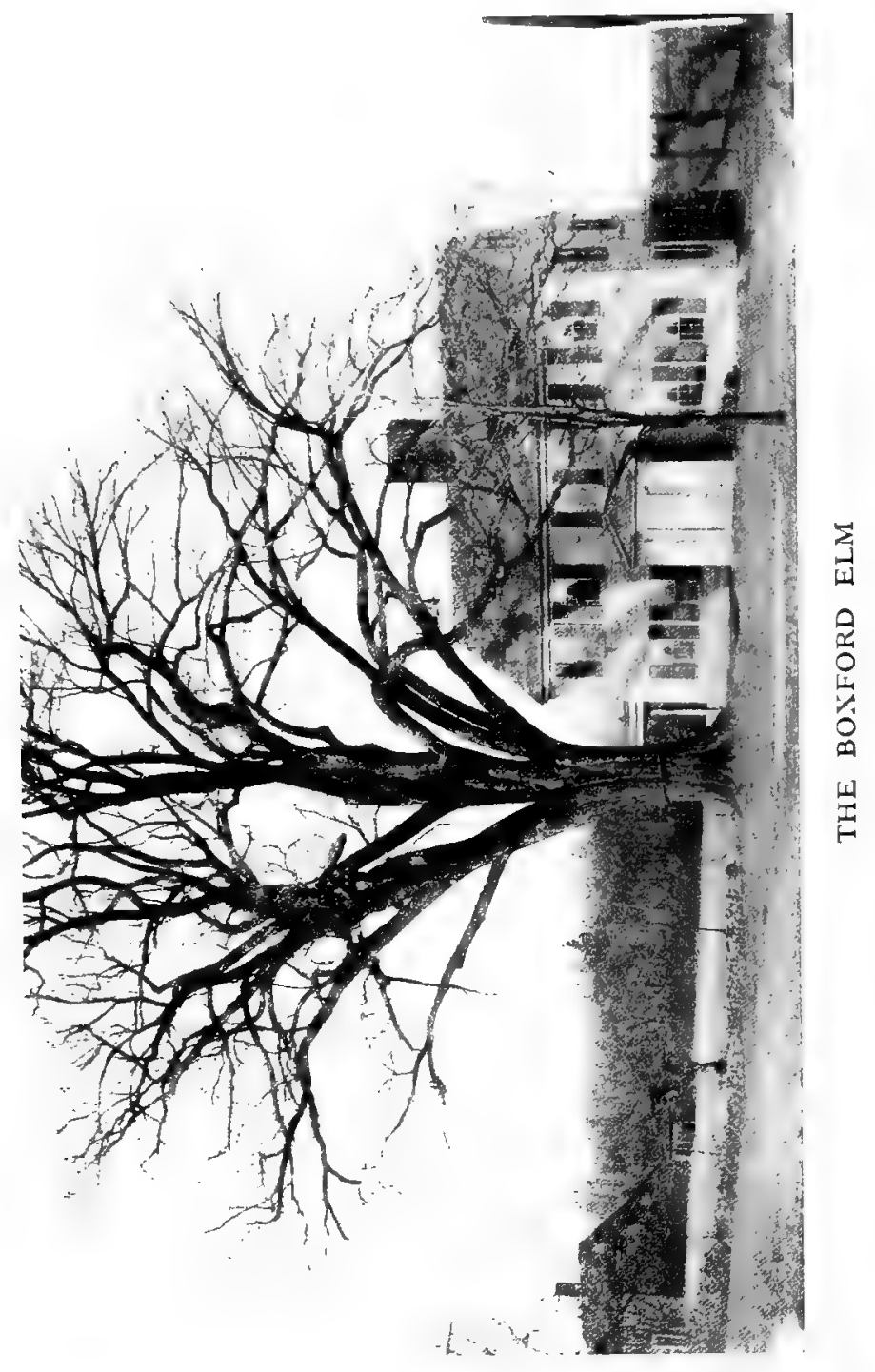



THE BOXFORD ELM

Nearly fifty years Iater, in 1700-0I, his three grandsons, Samuel English, Joseph English and John Umpee, claimed title to and demanded money for the territory included in Boxford. The town bounds at that time were substantially the same as now. On Jan. I5, I70I, a town meeting was held, at which John and Thomas Perley, John Peabody, Thomas Hazen and Joseph Bridges were chosen a committee to treat with the Indians relative to their demand, and were given full authority to settle the claim. All of these men were influential in the life of the town. The two Perleys and John Peabody had served as representatives in the General Court, and Hazen and Bridges were at that time serving as selectmen of Boxford.

The committee met the Indians at Thomas Perley's tavern, which stood on the site Iater occupied by the so-called Hale residence, now owned by Mr. Harry S. Perkins of Howe's Village, East Boxford, Mass., and conspicuously marked by a huge elm tree. In exchange for a new deed of the property in question, the Indians received eight pounds [6I] 
THE HISTORIC TREES OF MASSACHUSETTS

paid in money to Samuel English, and "two shillings and sixpence in silver and Rum and vittles enouf," paid to their two kinsmen.

This transaction settled for all time the question of title to the town of Boxford, and rendered the site of the Thomas Perley tavern historic ground. When Mr. Perley died in 1745 , his property was divided between his two sons, Thomas and Asa Perley, the latter receiving the portion on which the homestead stood. In 1760 Asa Perley took down the old tavern and erected upon the spot a new dwelling house, and planted directly in front of it "the sapling elm." Both house and tree have since remained as cherished landmarks of Boxford, as well as of Essex County.

Out from the shade of the elm tree, where they had played as children, seven stalwart sons of Asa Perley marched forth to the Revolution; and General Israel Putnam, who was a step-son of their grandfather, Thomas Perley, by the Iatter's marriage to Elizabeth Putnam, widow of Joseph Putnam, [62] 


\section{THE BOXFORD ELM}

spent many a happy day beneath this same tree, both before and after he became famous.

The sapling eIm gradually developed into a great tree - one of the greatest in Massachusetts. It has, at the present time, a circumference at breast height of fourteen feet, four and a half inches; a height of seventy feet, and a spread of one hundred feet. At about ten or twelve feet from the ground the trunk divides into frve large branches which in turn subdivide to form a broad crown, overtopping the old colonial residence, and lending its charm to the whole country-side. ${ }^{1}$

1 The authority for the historic facts contained in this chapter is Mr. Sidney Perley who has written several books on the town of Boxford, among which are: "History of Boxford," "Indian Land Titles of Essex County," and "Dwellings of Boxford." 
CHAPTER XII

\section{THE ENDICOTT PEAR TREE}

The days that are no more, and come no more, When as a child you sat upon my knee,

And prattled of your playthings, and the games

You played among the pear trees in the orchard.

Longfellow

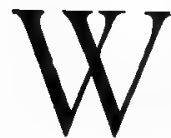

HEN selecting a young tree for planting as a permanent, living monument, capable of occupying

a given spot for from one hundred to frve hundred years, one would hardly choose, out of all the available species, a fruit tree. And yet John Endicott, the earliest pioneer of the Massachusetts settlement under the patent, has left behind him a pear tree which he planted about the year 1632, and which still "bears more fruit than the whole town can eat" as the people say in Danvers.

Endicott in addition to being a devout Puritan, and an intrepid and successful leader, was also a lover of trees and shrubs, with an especial leaning toward the fruit-bearing [64] 


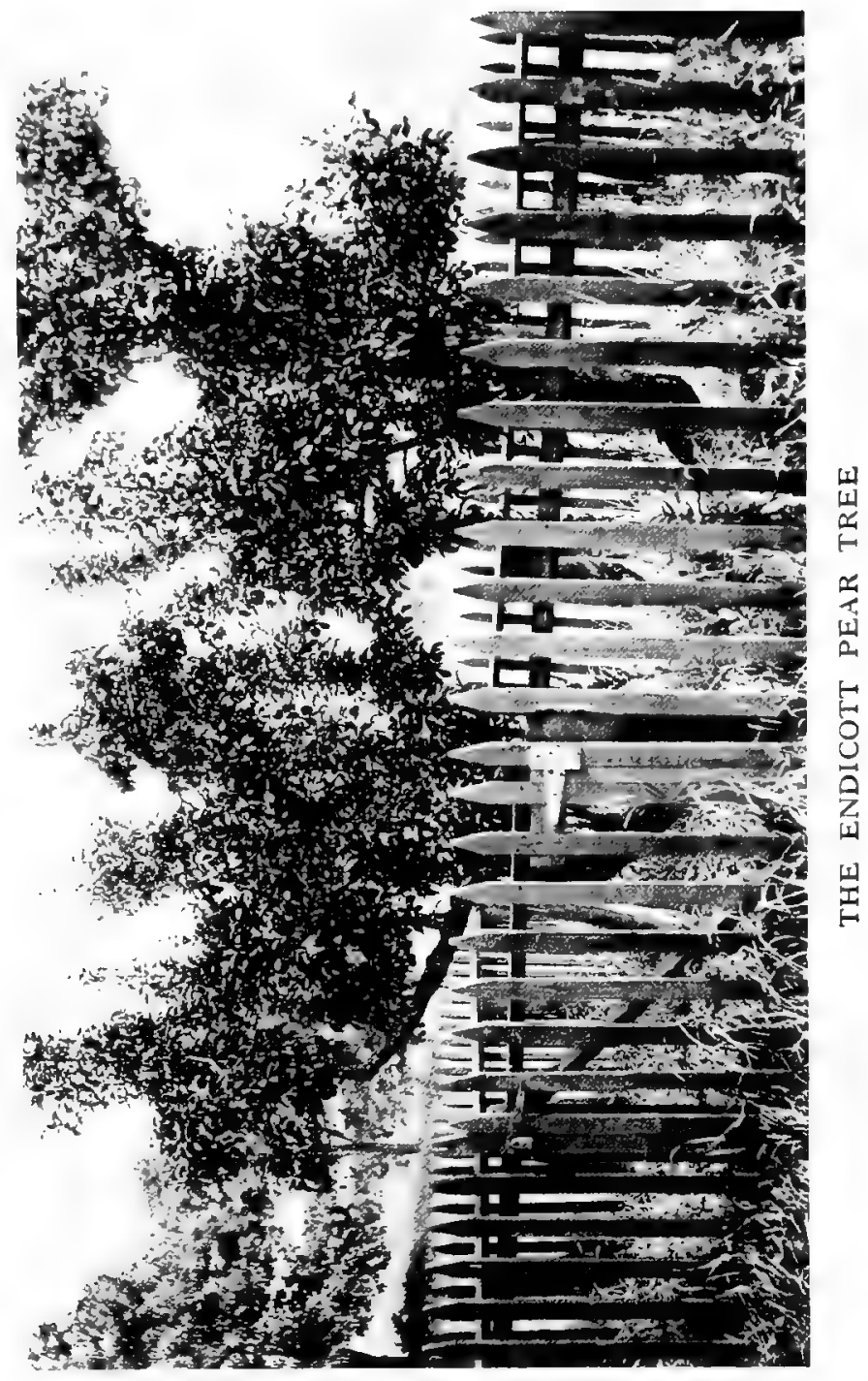



varieties. Mr. Higginson, who came to the colony in June, 1629 , records the fact that "Our Governor hath already planted a vineyard, with great hopes of increase. Also mulberries, plums, raspberries, currants, chestnuts, filberts, walnuts, small nuts, hurtle berries and haws of white thorn, near as good as our cherries in England - they grow in plenty here." ${ }_{1}$

This unusual variety of good things was probably transferred to the "Orchard Farm," so called, consisting of three hundred acres, given to Governor Endicott as the first grant in 1632, and confirmed by the Colonial Authorities in that year. It was called "a necke of land lying about three miles from Salem," and was known by the Indians as Wahquamesehcok (birchwood). ${ }^{2}$

Authorities differ as to the probable date of the planting of the pear tree, which has survived all of its companions. According to a family tradition, Endicott's dial, bearing date of 1630 , and the fruit trees, including

1 See "Memoir of John Endicott" by Chas. E. Endicott.

2 Hanson, "Hist. of Danvers." 
THE HISTORIC TREES OF MASSACHUSETTS

the celebrated pear, were ordered at the same time. If this is true it is reasonable to suppose that the trees were planted at the Governor's residence in 1630 , and in their permanent places at Orchard Farm as soon as that land was under cultivation, about 1633. Hanson's "History of Danvers" quotes Joselyn, 1639, as saying, "There is not a single apple tree or pear tree in all the colonies" and adds that either the shoot was brought over subsequent to 1639 or Joselyn did not know of its existence. The writer's own opinion is that $r 630$ is the probable date for the arrival of this tree in America. For out of all that wealth of trees and shrubs, particularly fruit-bearing species, with which the Governor surrounded himself from 1629 to 1633 , he would hardly have overlooked the apple and the pear. These trees may have been in the minority, and therefore overlooked by the outside observer.

There is not much left of beauty or comeliness about the venerable tree which still maintains its layer of living bark from year to year around a hollow trunk, and still [66] 
drops down its golden fruit into the laps of Endicott's grateful descendants and admirers. Could the old Puritan see it at this time he would say, with Touchstone, "An ill-favored thing, sir, but mine own"; and he might well add, "Rich honesty dwells like a miser, sir, in a poor house." When in leaf, however, the tree possesses a youthful appearance, as the photograph will show.

The local historian, J. W. Hanson, pays a fitting tribute in his "History of Danvers" when he says, "The man of the present day who stands beneath its shadow cannot repress the mingling emotions which rise in his Soul. In its nestling boughs he surveys the past and beholds the light of other days."

Measurements have no value and convey no meaning, as applied to this tree. Soil has gradually collected about the trunk until the two main branches appear to rise from the ground as separate trees. They evidently join under a heavy covering of sod. Surrounding them is a fence which acts as an effective protection. When the author photographed the tree it was covered with 
THE HISTORIC TREES OF MASSACHUSETTS green fruit. It may be seen in a freld near Endicott street at Danversport, and is worth turning aside to behold, for it is one of the most quaint and strangely impressive of all the historic trees.

[68] 


\section{CHAPTER XIII}

\section{LEXINGTON AND CONCORD TREES}

Here once the embattled farmers stood, And frred the shot heard round the world.

\section{Emerson}

MONG that small band of patriots
who placed themselves across the
path of the advancing British army at Lexington Common, on the 19th of April, I775, was a lad of seventeen - Jonathan Harrington. He was the fifer of Capt. Parker's company, and, with his brave companions-in-arms, responded to the famous command, "Stand your ground, don't fire unIess fired upon, but if they want to have a war let it begin here!"

In the frght which followed, the percentage of killed and wounded, in relation to the number of men engaged on the side of the patriots, was greater than in almost any other famous battle of our history; and 
among the dead were found two worthy representatives of the name of Harrington. They fell, the one upon his own door-step, and the other while escaping from the meeting-house where the military supplies were stored.

Jonathan Harrington, the fifer, came out of the battle of Lexington unscathed, and lived to the ripe old age of ninety-six, being the last survivor of those who took part. His death in 1854 produced a remarkable effect, both on the community and throughout the state. His funeral was attended by the Governor and his Council, the LieutenantGovernor, the Senate and House of Representatives, and by many prominent citizens. Two companies of militia, ordered out by the Governor for the occasion, fired a volley over the grave.

The distinction Jonathan Harrington enjoyed, as the result of his long and interesting career, has shed its glow upon a certain favorite tree, planted by his father. It bears the name of "The Harrington Elm," and stands in front of the L. A. Austin place $[70]$ 


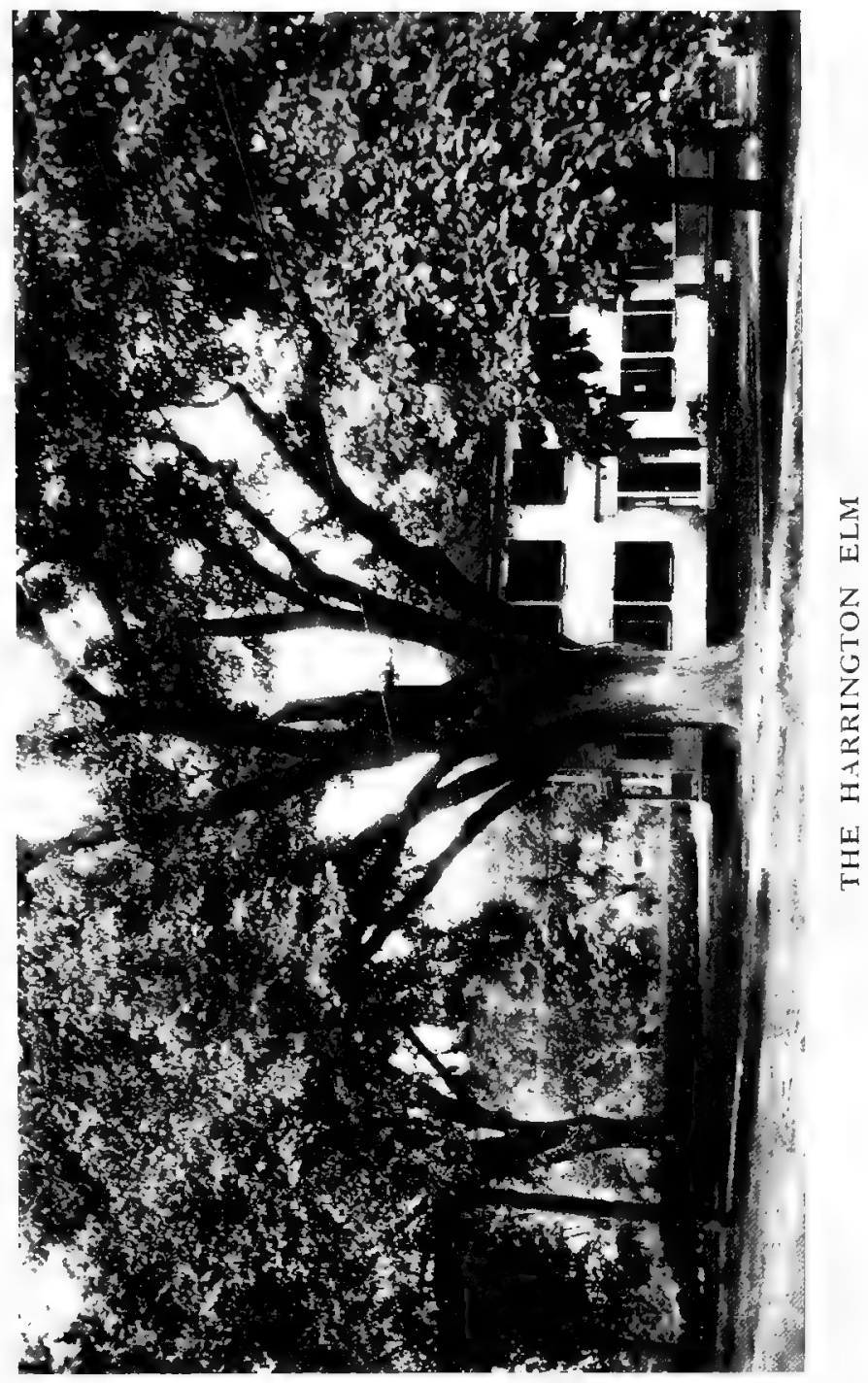




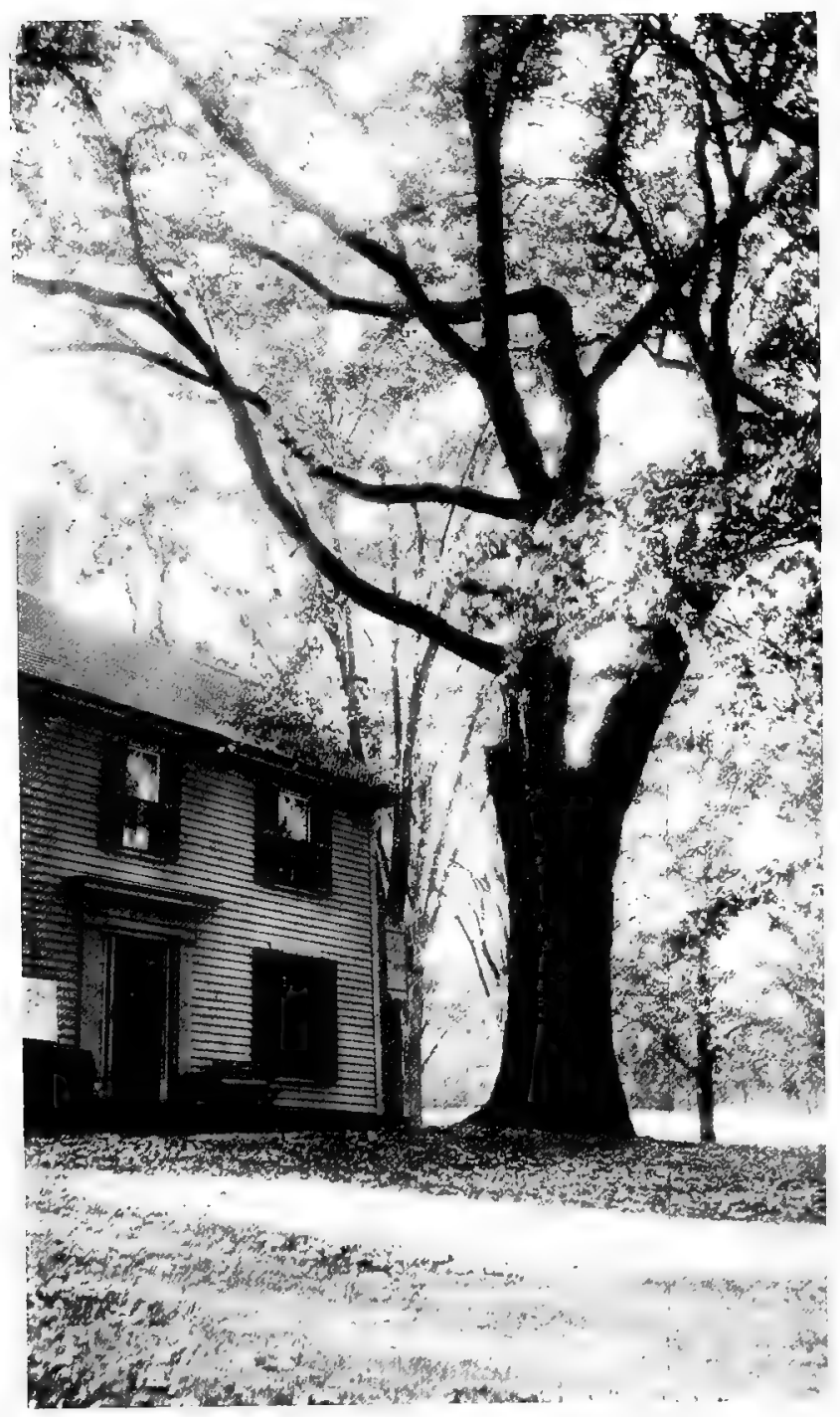

THE ELM AT MONROE TAVERN, LEXINGTON 


\section{LEXINGTON AND CONCORD TREES}

on Massachusetts Avenue, East Lexington. A legend upon its trunk informs us that

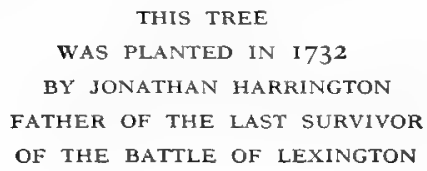

It is seventy feet in height, sixteen feet, four inches in circumference and ninety feet in the spread of its branches. At about ten feet the trunk divides into four great limbs. One of these, on the northerly side, divides again into four branches. There were originally frve sub-divisions to the trunk, but one fell in a heavy gale. The wound has been treated and is properly healing.

As you pass on from the Harrington Elm towards the historic common, the "Old Monroe Tavern" presents itself to your view on the left side of the road. Directly in front of it may be seen another beautiful elm, slightly smaller in girth, but nearly equal in height and spread to the elm just described. Here, on the day of the battle horses were tied to a series of iron spikes, driven at intervals of several inches, around 
THE HISTORIC TREES OF MASSACHUSETTS

the tree. One of these, over which the bark has not yet closed, may still be seen about an inch and a half below the surface. This spike is exactly four and a half feet from the ground. The circumference of the tree at this point is fourteen feet and frve inches.

Another tree which is sure to arrest the attention, even of the casual observer, is the ash which stands near the monument on Lexington common, where the remains of those who feIl in the battle were finally brought and buried. It is reasonable to suppose that this tree was standing when the battle of Lexington was fought. The circumference is fourteen feet.

Here the advance of the British ceases to be associated with great trees until Concord is reached, where several ashes, elms, buttonwoods and oaks may be found, bearing upon their forms the marks of antiquity. But strangely enough not one has been selected and classified as historic.

The elm in front of the town hall must have towered above the British army as it $[72]$ 


\section{LEXINGTON AND CONCORD TREES}

halted in the center of the town. It is fifteen and a half feet in circumference. The buttonwood in front of the Jesse C. Brown house, and the eIm in the middle of the sidewalk in front of the C. F. Haywood place, both on Lexington Road, must have looked sternly down upon the tramping throng as it came and departed. Each tree is more than twelve feet in circumference, and the elm increases by huge abutments until, at the ground, the circumference is nearly doubled.

On the bank of the Concord River, just beyond the Monument Street bridge, and not far from the famous "monument of the minute-man" there is a very old willow tree. Its girth is greater than that of any tree in Concord, and it is known to have been a sizable specimen even in Revolutionary times. The circumference at breast height, measured from the upper side is twentytwo feet; from the lower side it is eighteen feet and eight inches; the height is fortythree feet and the spread sixty-three feet. At the point where the branches emerge 
THE HISTORIC TREES OF MASSACHUSETTS

from the trunk the circumference is nearly thirty feet.

There are yet other trees in historic Concord, but they belong to a later time, and are associated with the years of peace and accomplishment rather than with those of war. They seem to have been more cherished than any of the others. The writer refers to the two old elms in front of the Louisa May Alcott house, and the little grove of pines and spruces just beyond it. Under the shade of the elms once lived the author of "Little Women," and among the whispering pines Hawthorne walked, thought and wrote, or conversed with his friend Thoreau.

The elm at the left of the door as the visitor approaches the old house is thirteen feet in circumference, and the one at the right is fifteen feet. Their height is about sixty-five feet. The spread of the branches is not imposing, as one of the trees has lost nearly half of its limbs.

The pines and spruces are tall, with clean boles and healthy crowns; within their deepest shades an attractive boulder [74] 


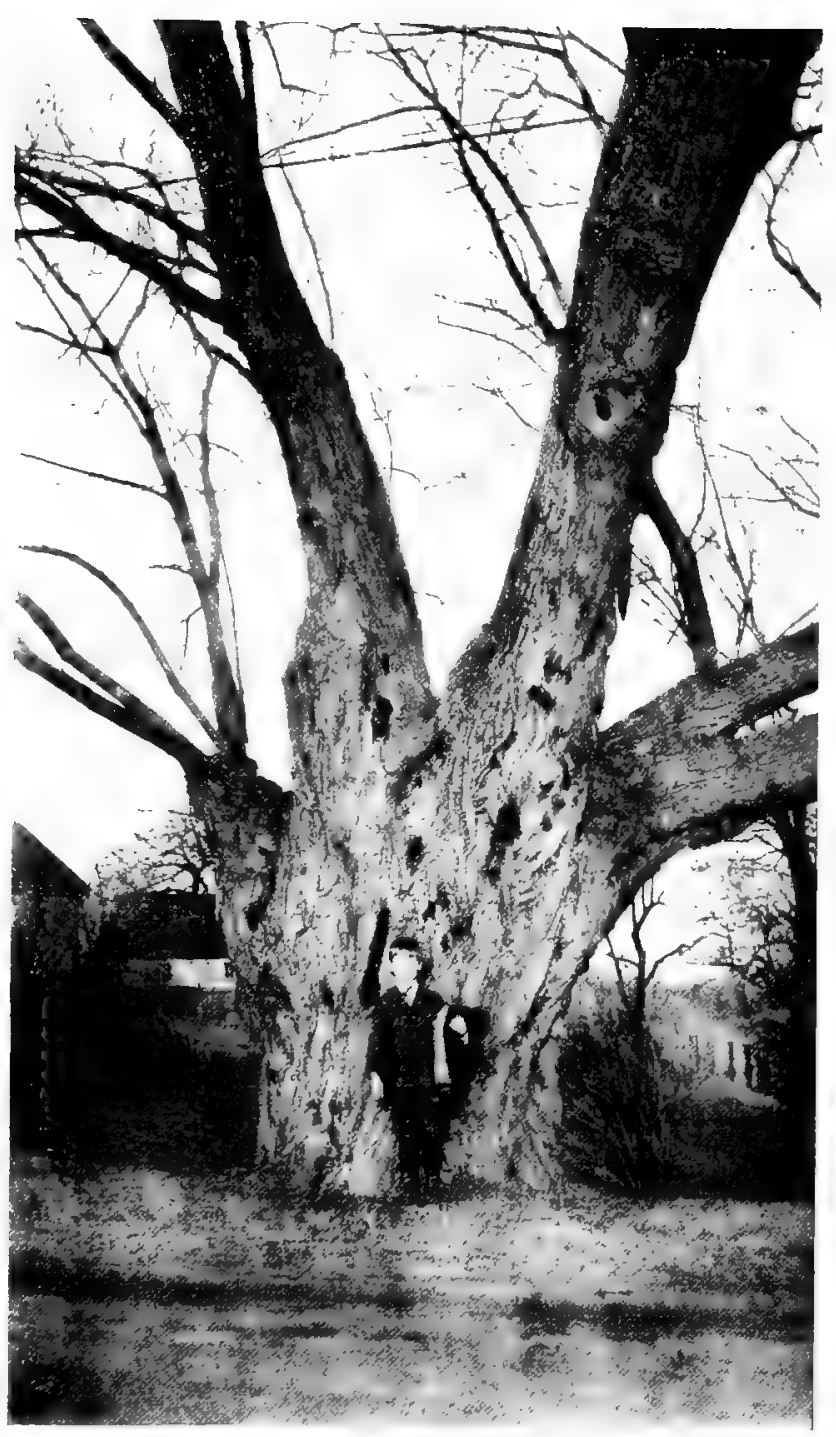

THE OLD WILLOW AT CONCORD 


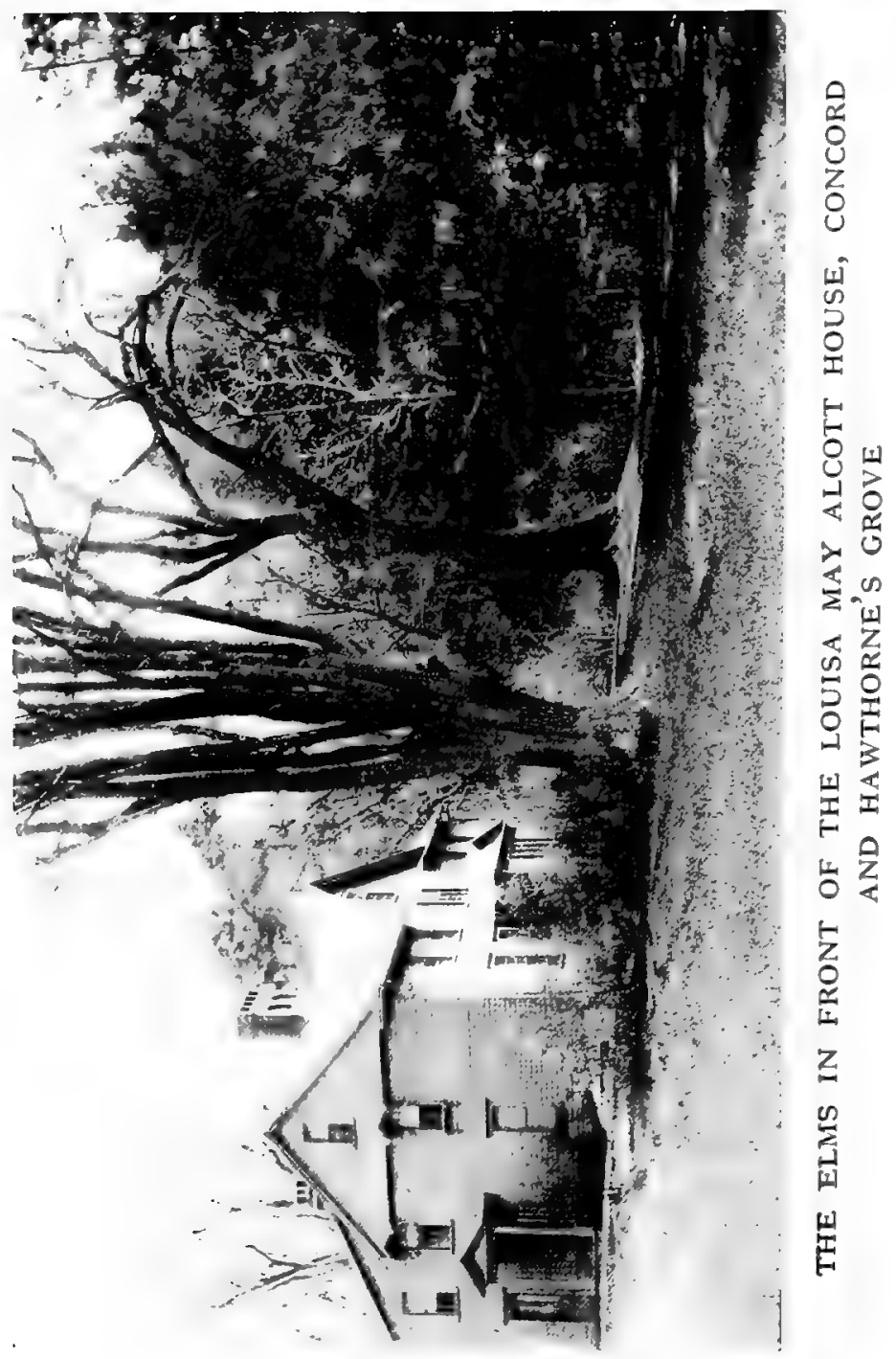




\section{LEXINGTON AND CONCORD TREES}

has been placed, which bears the following inscription:

THIS TABLET PLACED

AT THE CENTENNIAL EXERCISES

JULY 4, IgO4

COMMEMORATES

NATHANIEL HAWTHORNE.

HE TROD DAILY THIS PATH TO THE HILL

TO FORMULATE

AS HE PACED TO AND FRO

UPON ITS SUMMIT

HIS MARVELOUS ROMANCES 


\section{CHAPTER XIV}

\section{THE ANCIENT OAKS AT WAYSIDE INN}

By noon and night the panting teams,

Stop under the great oaks that throw

Tangles of light and shade below,

On roofs and doors and window-sills.

Longfellow

BOUT twenty miles west of Boston,
in the town of Sudbury, there is a
very old and very famous inn known as Longfellow's Wayside Inn. It is celebrated for its beautiful collection of antiques, its remarkable fire-places and the attractive arrangement of its many rooms; but chiefly for the Iure that surrounds it by reason of the noted personalities who have been associated with the place and its vicinity. Washington and Lafayette stopped there during Revolutionary times, and there the beloved American poet Longfellow found the inspiration for some of his best poetical works.

Opposite the east wing, and on either side of the State Road, stand the Ancient [76] 


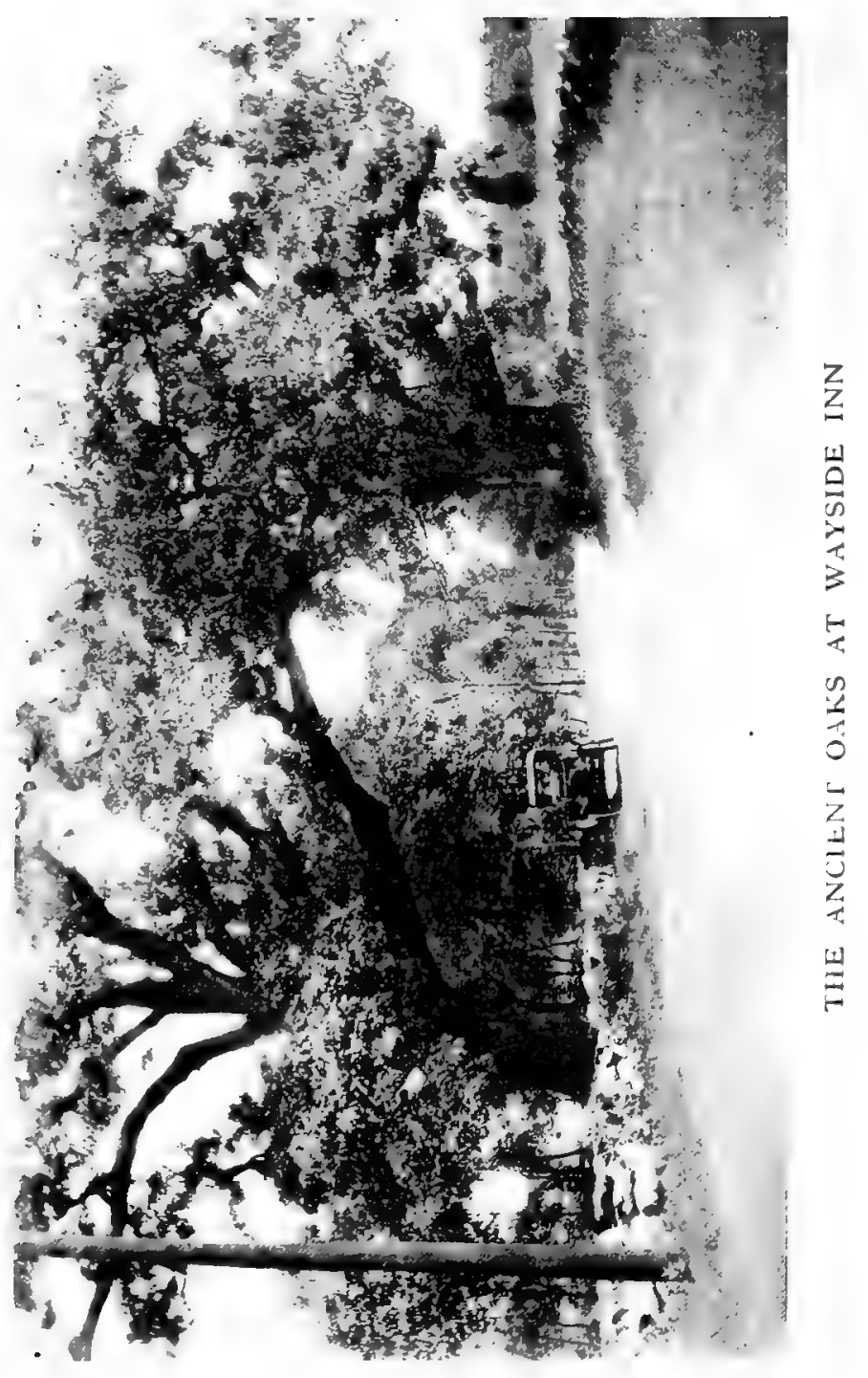


THE ANCIENT OAKS AT WAYSIDE INN

Oaks, measuring 18 feet, $2 \frac{1}{2}$ inches, and 17 feet, 7 inches respectively, and spreading their powerful branches over a space of more than 200 feet. They are so nearly alike in form and in the color of the bark that they are usually mistaken for white oaks, and considered the Iargest pair of this species in New England. But upon more careful study it will be noted that the smaller tree, i.e., the one within the bounds of the highway, is a red oak, while the one within the grounds of the Inn is a white oak.

These trees were standing here in June, 1775, when Washington passed on his way to Cambridge to take command of the Patriot army; and again about a century later they were rendered famous by Longfellow in his "Tales of a Wayside Inn," when

Through the ancient oaks o'erhead, Mysterious voices moaned and fled.

The age of the Ancient Oaks is unknown, but it is claimed that they existed fuII grown before the Inn was built, and are at least 500 years old. The white oak is hollow, and 
THE HISTORIC TREES OF MASSACHUSETTS

would house several persons within its trunk. Tree-surgeons have removed the dead wood from within and braced the walls of the trunk against the elements and the strain of the great branches. Seed continues to be borne in abundance each year, and the surrounding frelds contain many large and beautiful oaks - the children and grandchildren of these giants of the forest primeval. 


\section{CHAPTER XV}

\section{THE MARLBORO ELM}

Lean close and set thine ear against the bark;

Then tell me what faint, murmurous sounds are heard.

Cbarles Henry Luders

THE road over which Washington passed on his way to Cambridge is still the favorite highway between Springfreld and Worcester, and between Worcester and Boston. It has now become the popular automobile route between those cities, and many a beautiful tree greets the traveler with its grateful shade. After passing the oId oaks at Wayside Inn, going towards the west, you enter the town of Marlboro. A large sign informs you that this town is the seventh in shoe production in the state, and that it is "clean, healthy and prosperous." Near the end of West Main street, on the lawn of the Stevens place stands an old elm tree, the dimensions of which are quite extraordinary: circumference at breast height, $17 \frac{1}{2}$ feet, height, 
THE HISTORIC TREES OF MASSACHUSETTS

$74 \frac{1}{2}$ feet, spread of branches, roo feet. The roots on the southerly side rise from the ground like an abutment, increasing the circumference at one foot from the ground to $29 \frac{1}{2}$ feet. The branches are unusually large, and in a pocket of earth which has collected among them at the top of the trunk, a currant bush has been bearing fruit for sixty years. This fact is vouched for by Mr. William Arnold who worked for William Gibbon, a former owner of the property on which the tree stands, when a boy.

The tree is historic on account of its connection with the old house just behind it, and its age dates back as far, at least, as I740, when it was much prized by a Tory minister of Marlboro, the Rev. Aaron Smith. "The house was erected by the town for the Rev. Aaron Smith upon his settlement here in 1740. At the time of the Revolution, this man was suspected of Tory sentiments, and one night two loaded muskets were fired into his window, probably as a threat or warning by individuals who, actuated by the spirit of the time, gave vent to their detestation [80] 


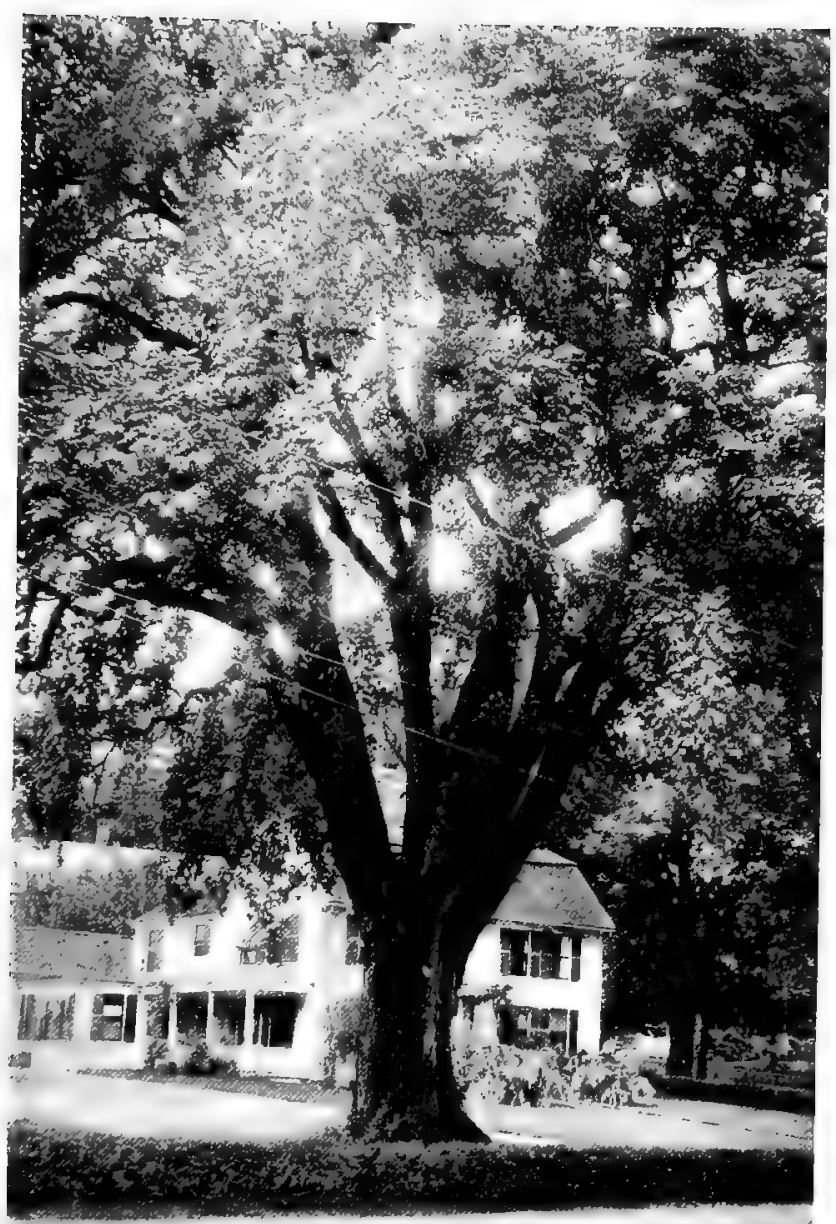

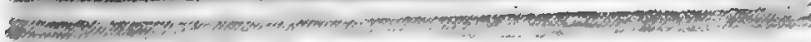

i $\cdots$

THE MARLBORO ELM 
of anyone who could possibly make harder the struggle of a feeble province, almost without arms and ammunition of war against the then most powerful nation of the earth. The bullets fired lodged in a beam, and were extracted and preserved by Mr. Samuel Gibbon. Rev. Smith, becoming less popular, and because of impaired voice resigned the ministry here and in 1778 removed to Wayland where he died three years Iater. In I784, Mr. Samuel Gibbon came with his wife from Dedham and bought this old house, improving it in many ways. He was a trader, a prominent citizen and many years a Justice of the Peace. He also represented the town in the Legislature. Samuel Gibbon willed the old homestead to his son who cared for his father to his death. The property eventually passed into the hands of William Gibbon's daughter Mary, who married Frank Howe, and, in 1903, the place was purchased by Dr. Ralph E. Stevens who with his family resides in this, one of Marlboro's oldest landmarks." 1

1 Ella A. Bigelow, "Historical Reminiscences of Marlboro," Chap. 2. 
THE HISTORIC TREES OF MASSACHUSETTS

When the writer visited the property for the purpose of taking measurements of the tree he was shown one of the old musketballs referred to. It was of Iead, about as large as a medium-sized hickory nut, and would unquestionably have produced a more ragged wound, had it struck the Rev. Smith, than the steel-jacketed variety of modern times. Judging from the angle at which the bullets entered the beam they were fired from a point a few feet to the right of the tree.

Another elm that has become a favorite with many people on account of its symmetry and great size, stands near the State Road a few miles further on, or about midway between Northboro and Shrewsbury. The circumference is about is feet.

$[82]$ 


\section{CHAPTER XVI \\ THE GRAFTON OAK}

In all that proud old world beyond the deep

E'er wore his crown as loftily as he

Wears the green coronal of leaves with which

Thy hand has graced him.

Bryant

W

HILE the Patriots in Boston were rallying beneath the branches of Liberty Tree and the Great EIm, events of a similar nature were taking place in one of the small towns in the center of the state.

Not far from the town square in Grafton, on a street leading down the hill on the northerly side, stands a very fine red oak, bearing an inscription on a copper tablet:

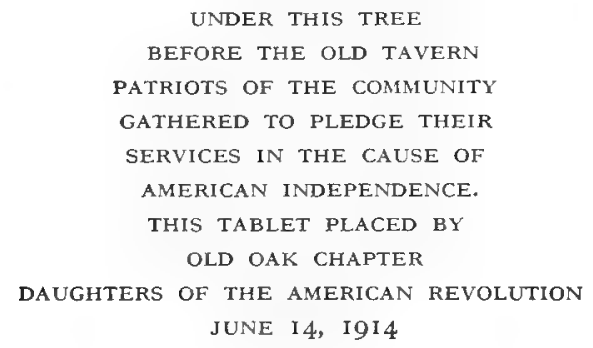


THE HISTORIC TREES OF MASSACHUSETTS

This oak is 14 feet, 5 inches in circumference, 62 feet in height, and 75 feet in the spread of its branches. It has witnessed some stirring scenes, among which may be mentioned the departure of the two companies of volunteers, composing "the whole efficient male population of the town" on the day of the battle at Concord and Lexington; and in Iater years the departure of Company $G$ of the Fifteenth Regiment, Massachusetts Volunteers, at the opening of the Civil War. According to Pierce's History of Grafton, when this later company was being formed, upon receipt of the news of the attack on the Massachusetts Sixth Regiment at Baltimore, a soldier of the Revolution, Benjamin Smith, ninety-eight years old, attended the meetings and spoke from the platform of the town hall. A monument in the town square records the names of fifty-nine victims which Grafton gave for the life of the nation. ${ }^{1}$

1 Pierce, "Hist. of Grafton," pp. 10 $5-6$.

[84] 


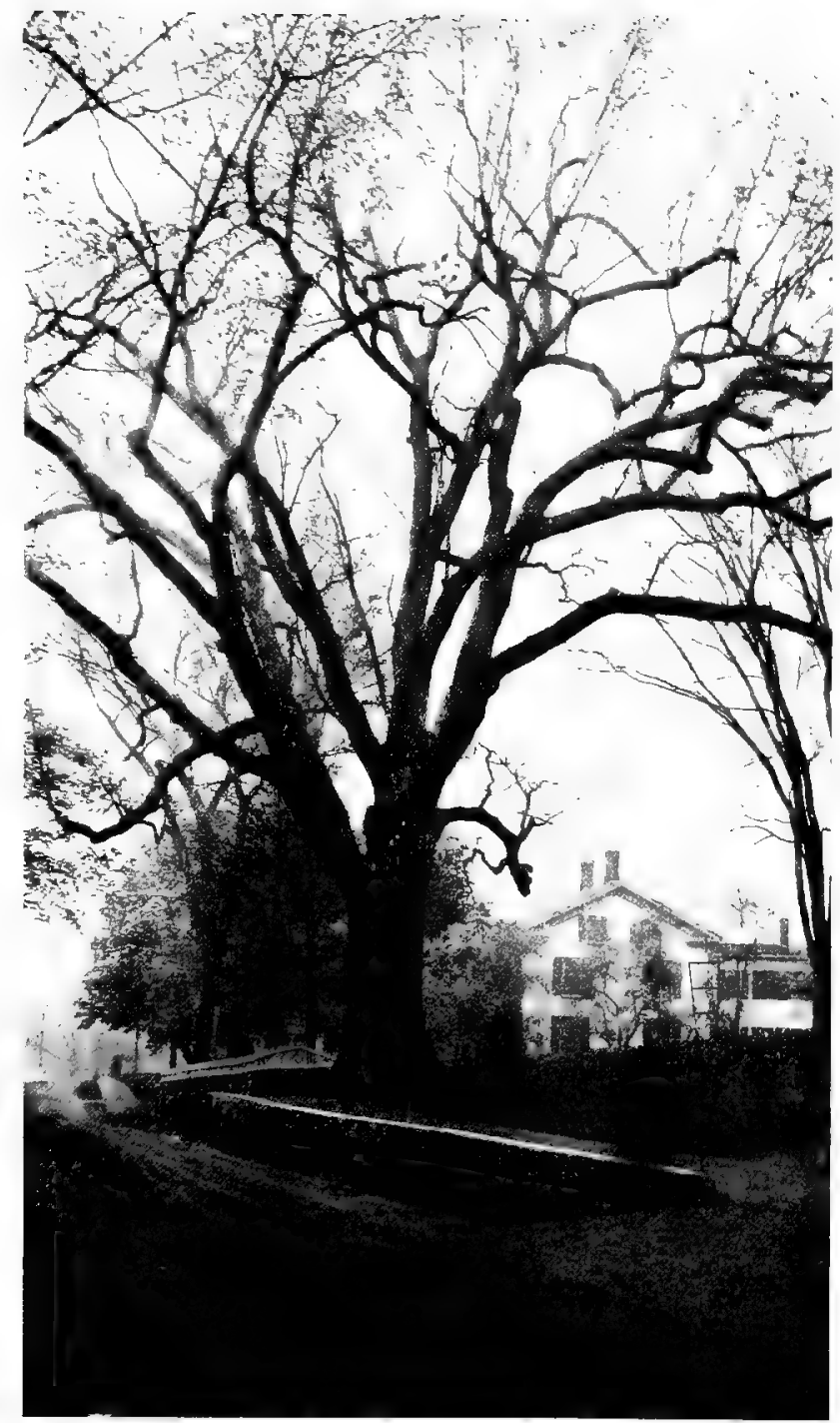

THE GRAFTON OAK 



\section{CHAPTER XVII}

\section{THE WASHINGTON ELM AT PALMER}

In June 'tis good to lie beneath a tree.

Lowell

\section{HEN the old elm at Cambridge $^{\text {HEN }}$ has at last been added to the list of the historic trees of the past,} there will still be standing a tree of the same species, bearing the same name; for just beyond the town of Palmer, a quarter of a mile from the railroad bridge, and near the center of a broad curve of the main road to Springfreld, is a wide-spreading elm of the oak-tree type, comparatively strong, and most pleasing in its proportions.

Beneath this tree Washington rested and refreshed himself, and delivered a short address only three days previous to taking command of the army at Cambridge. A local historian informs us that the place was an old tavern-stand once owned by Daniel Graves who obtained a license to keep the house of 
THE HISTORIC TREES OF MASSACHUSETTS

entertainment before 1760 , which later was renewed to his son Aaron, in $176 \mathrm{I}$. This son, as Captain, served in the Revolutionary War and afterward rose to the rank of major. He kept the tavern during his lifetime. ${ }^{1}$

"The elm took its name from the tradition, apparently well attested, that General Washington, accompanied by his Staff, General Lee and the deputation sent from Cambridge to Springfreld to meet and escort him to headquarters, halted with his party under the shade of this tree to rest and lunch about noon, June 30, I775. Very naturally the party ordered milk and otber necessaries from Captain Graves's tavern."'1

There is a granite monument a few feet from the base of the tree which bears the following inscription:

$$
\begin{gathered}
\text { UNDER THIS ELM } \\
\text { WASHINGTON } \\
\text { PASSED JUNE 30, 1775 } \\
\text { AND AGAIN OCT. 22, I789. } \\
\text { ON THE FIRST DATE TRADITION SAYS } \\
\text { HE ADDRESSED THE CITIZENS OF } \\
\text { PALMER. } \\
\text { ERECTED BY THE } \\
\text { PALMER HISTORICAL SOCIETY } \\
\text { JUNE 30, IgO6 } \\
\text { 1 Temple, "History of Palmer." }
\end{gathered}
$$




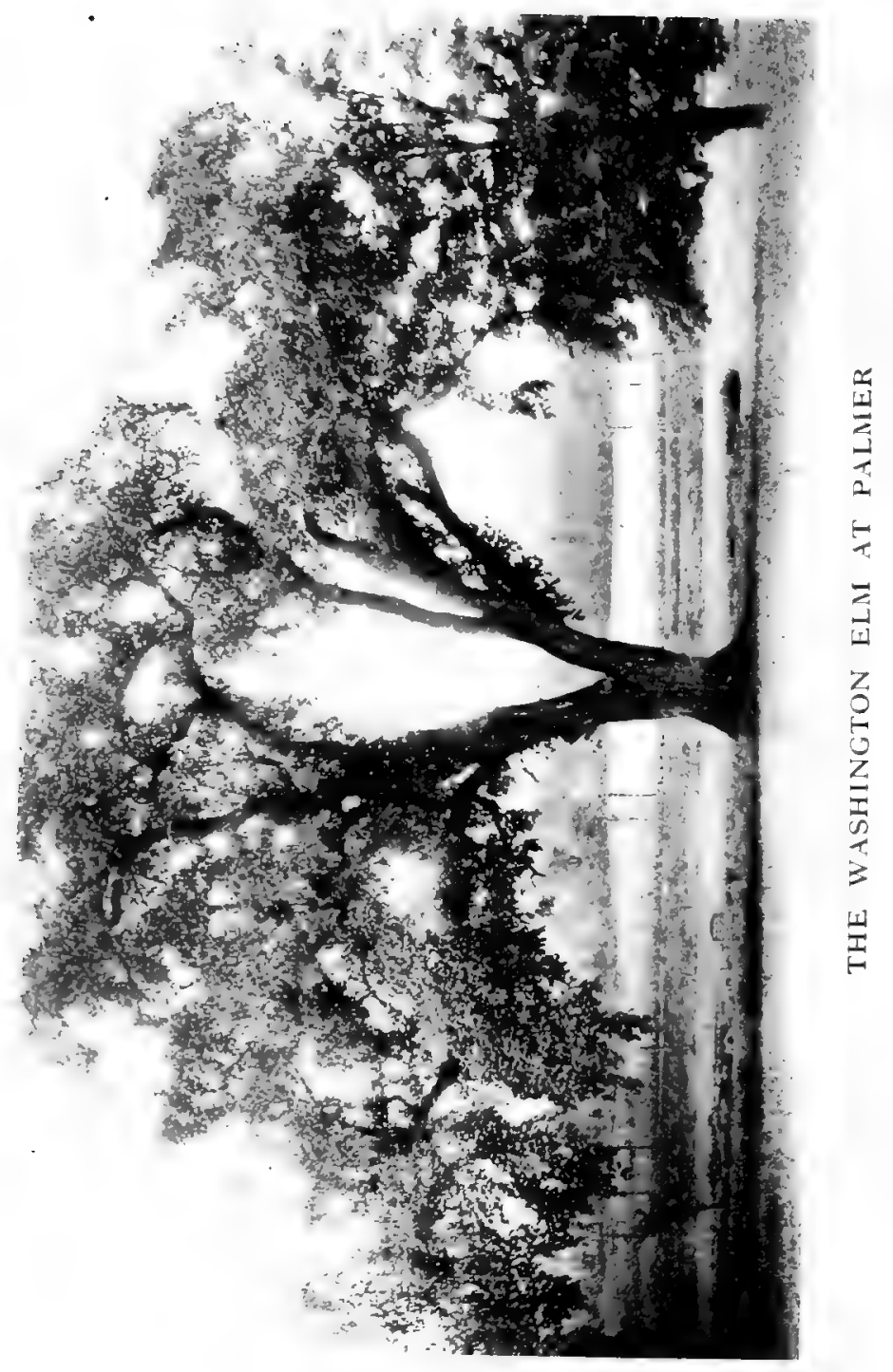



Like many trees of its kind this elm has developed greatly at the base. At one foot from the ground the circumference of the trunk is nineteen feet. At breast height it diminishes to fourteen feet and one inch, and increases again as the branches are approached. The height is fifty-five feet, and the spread of branches ninety-frve feet. 
CHAPTER XVIII

THE LAFAYETTE ELM

Sirs, cover the while; the duke will drink under this tree.

Shakespeare

\section{MONG those few trees which, in A point of size, may be called elms 1 of the first class, is the Lafayette} Elm. This tree is situated southwest of the village of Ware, on the road to Palmer, and is twenty feet, seven inches in circumference, seventy-five feet in height, and one hundred and ten feet in the spread of its branches. The enormous trunk divides at about ten feet into three branches, the largest of which subdivides into four more. The smallest of the four is fifteen inches in diameter. In general appearance the tree is slightly over-developed on the east side, one great limb stretching in this direction for more than sixty-frve feet.

Tradition says that, during Revolutionary times, Lafayette rested underneath this tree [88] 


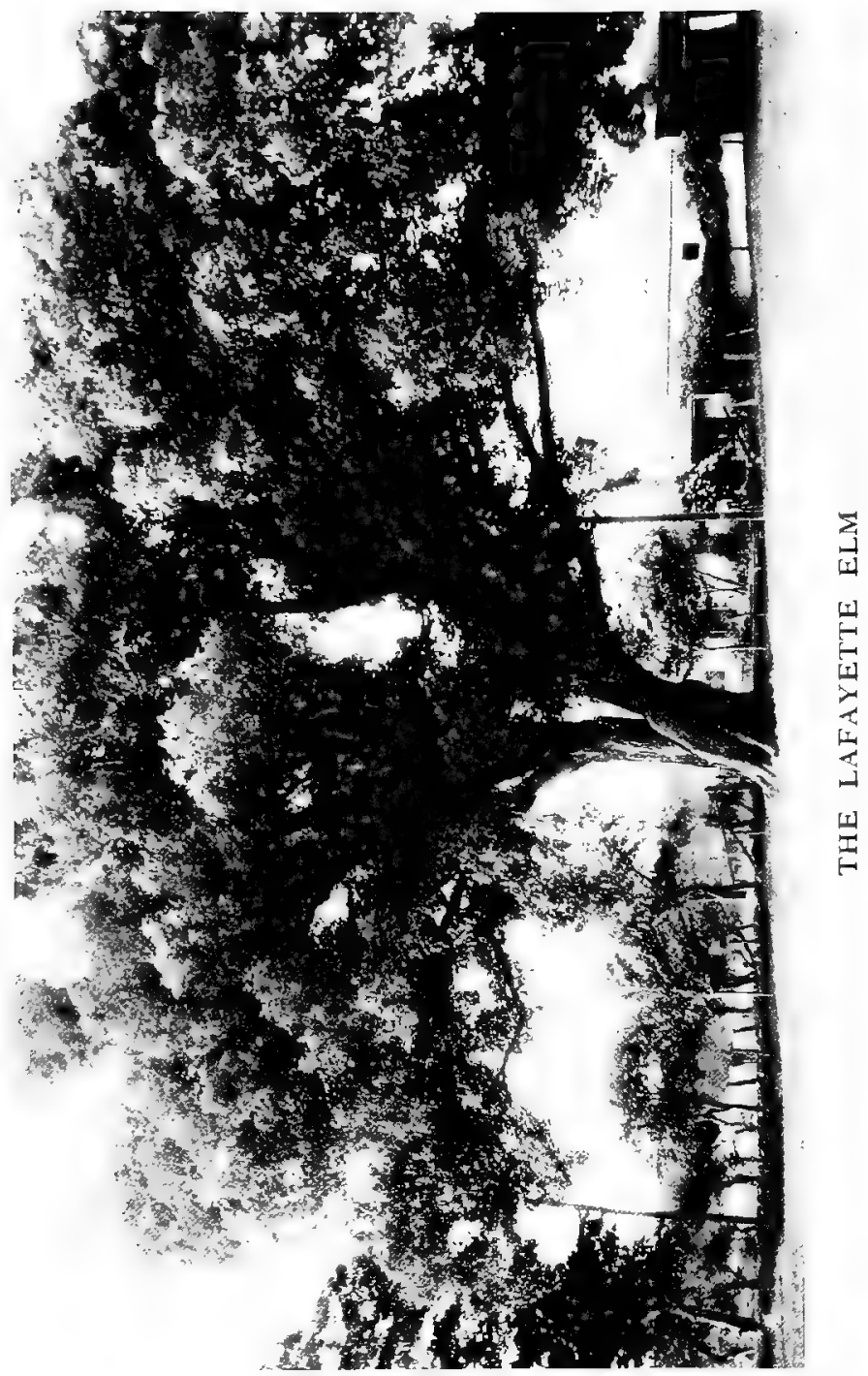



while on his way to meet Washington, and at a later date the elm was named for the famous Frenchman.

When the republic was firmly established, and Lafayette honored it with an extended visit, he stopped for a brief time in Ware and was entertained at the Old Tavern House. $^{1}$ Among those who met him at that time was Mrs. Cynthia Loomis, a life-long resident of the town, who recalls that, when he took her hand, he said to her and her companions, "I rejoice to see you, my children, enjoying the liberty for which we fought." 2

1 Where Hitchcock's block now stands.

2 Chase, "Hist. of Ware," p. I 20. 
THE ELM AT COURT SQUARE, SPRINGFIELD

And I, who have always known

Peace with her dove-like ways,

Am gripped with his martial spirit

Here in the after days.

Ricbard Burton

WHE city of Springfield has, from early times, possessed large numbers of

1 beautiful trees, mostly elms. The old Springfield EIm, now gone, was famous throughout Massachusetts, and another tree not quite so large is mentioned by Holmes in his comments in the "Autocrat" on elms of the second class, as "the queen of them all." ${ }_{1}$ There was also a "giant celtis," often mistaken for an elm, according to some authorities the finest tree of its kind in this part of the country. At West Springfield there was, until quite recently, a great tree known as the West Springfreld Elm.

1 Dr. Holmes considered a circumference of $14 \mathrm{ft}$. at $5 \mathrm{ft}$. from the ground, large, for elms; 16 to $18 \mathrm{ft}$., very large; $20 \mathrm{ft}$. exceptional.

[90] 


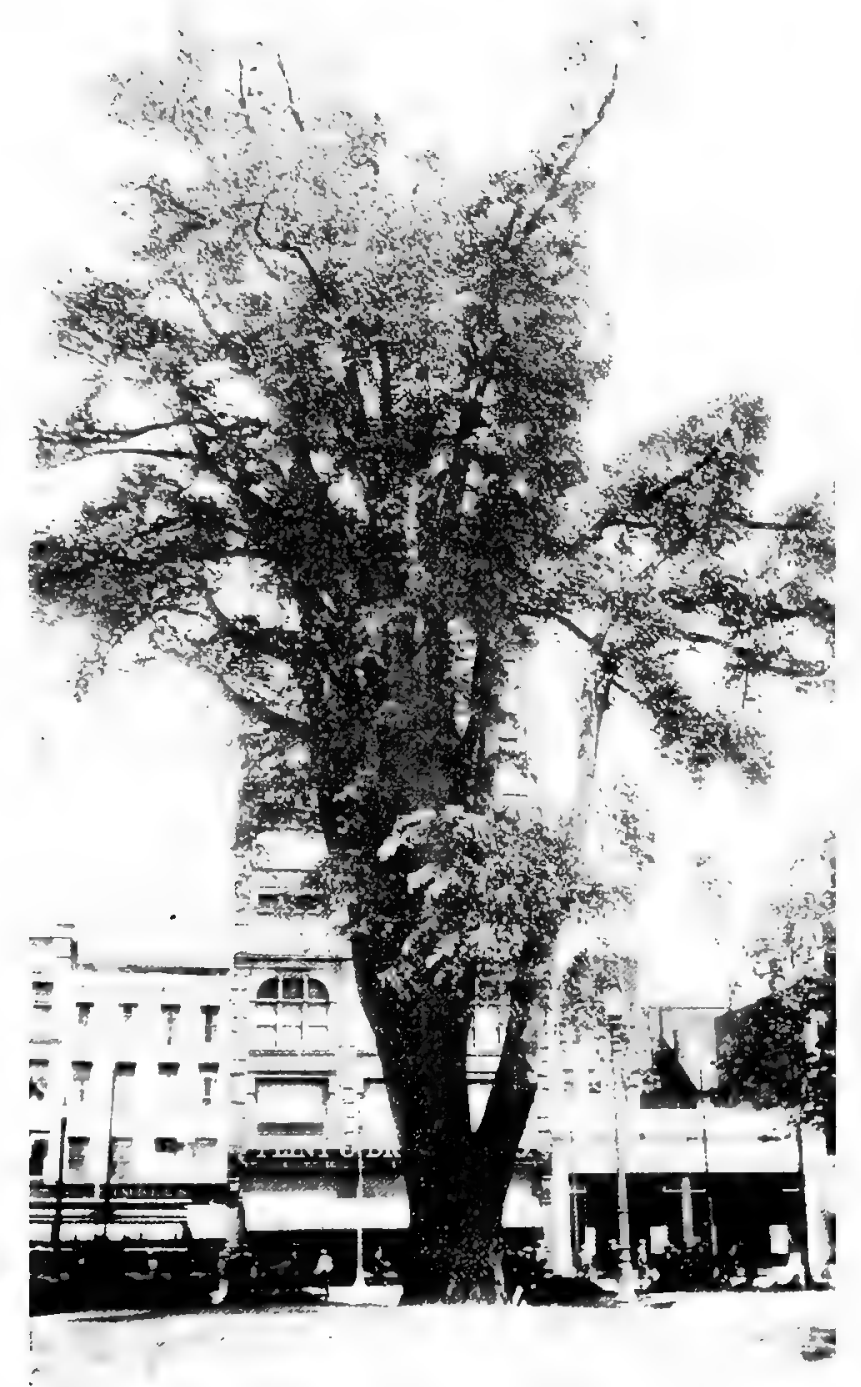

THE SPRINGFIELD ELM 

THE ELM AT COURT SQUARE, SPRINGFIELD

When these celebrities passed out of existence, the locality in which they stood ceased to be considered, by many, as the home of any trees possessing remarkable size or special marks of beauty; and yet some few have struggled bravely through the years, filling the places formerly occupied by their noble companions. One at least may be said to be historic, and as for size, it now measures up to all the requirements of an elm of the first class. It is the last survivor of a little group that stood in Court Square near the Old Tavern, "allowing the old yellow-bodied, thorough-braced stage just room enough to swing around to the front door in fine style!" 1

General Washington rendered the elms historic by his visit there when on his way between New York and Cambridge, and he rendered one more famous than the others, i.e., the elm that stood directly in front of the tavern door, for here it was that he sat and "drank his flip."

The city may well be proud to call the survivor of the group The Springfreld Elm.

1 King, "Hist. of Springfield," p. 234. 
THE HISTORIC TREES OF MASSACHUSETTS

It stretches its branches part way across Main street, where its green foliage may be seen in summer for a long distance as one approaches in either direction on the busy thoroughfare.

Its dimensions are surprising and gratifying - height I02 feet, spread II 2 feet, circumference at breast height, 19 feet, 9 inches. At five feet from the ground the circumference is a little over twenty feet, which, to some authorities, would mean more than the breast height measurement. Dr. Oliver Wendell Holmes would concede that this, in truth, constituted an exceptional elm. The tree has suffered severely from pruning, but is still sending out an abundance of foliage, and has the appearance of possessing great strength and durability.

Within a radius of a few miles from this point are three other trees which deserve mention here. One is the finest specimen of the hackberry that the writer has ever seen in New England. It stands, unfortunately, in an inconspicuous place, shut off from view by buildings, so that a good photograph is extremely diffrcult to obtain.

[92] 
THE ELM AT COURT SQUARE, SPRINGFIELD

The easiest way by which to direct the reader to this tree is to say that it stands directly in front of the jail. The distance is not far from the center of the city, and a view of the tree will repay any person for the journey. The circumference is 13 feet, Io inches, the height 78 feet, and the spread 80 feet - unusual, certainly, for this species.

In West Springfield, on the right hand side of the road leading to Westfreld, stands an old elm which is now in the early stages of decay. It is 95 feet in height, I 7 feet, 9 inches in circumference, and 75 feet in the spread of its branches.

At the end of Franklin street, in Westfield, where the tourist makes his last turn before ascending into the Berkshires, stands a large, old elm of the drooping type, possessing almost perfect proportions, against whose permanence and beauty no apparent inroads have been made. If this tree escapes accident from wind and lightning, it should live for at least another century. It has now reached the second class - circumference, I 6 feet, $7 \frac{1}{2}$ inches, height, 72 feet, spread, Ioo feet. 
CHAPTER XX

THE SHEFFIELD ELM

Here still an aged EIm aspires,

Beneath whose far projecting shade

(And which the shepherd still admires)

The children of the forest played.

Pbilip Freneau

LIVER WENDELL HOLMES, in speaking of his "tree wives," includes, among those of greatest size, beauty and symmetry of form, the eIm at Sheffreld, and adds that "size, first of all and chiefly" constitutes a first class elm.

Doubtless the Sheffreld elm was so classifred on account of its great beauty and spread of branches, for it fails to show twenty feet of clear girth at frve feet from the ground even at the present time. It has aIways been considered as one of the most beautifuI elms in Massachusetts, and though oId age has at last crept upon it, the individuality in the arrangement of its numerous branches [94] 


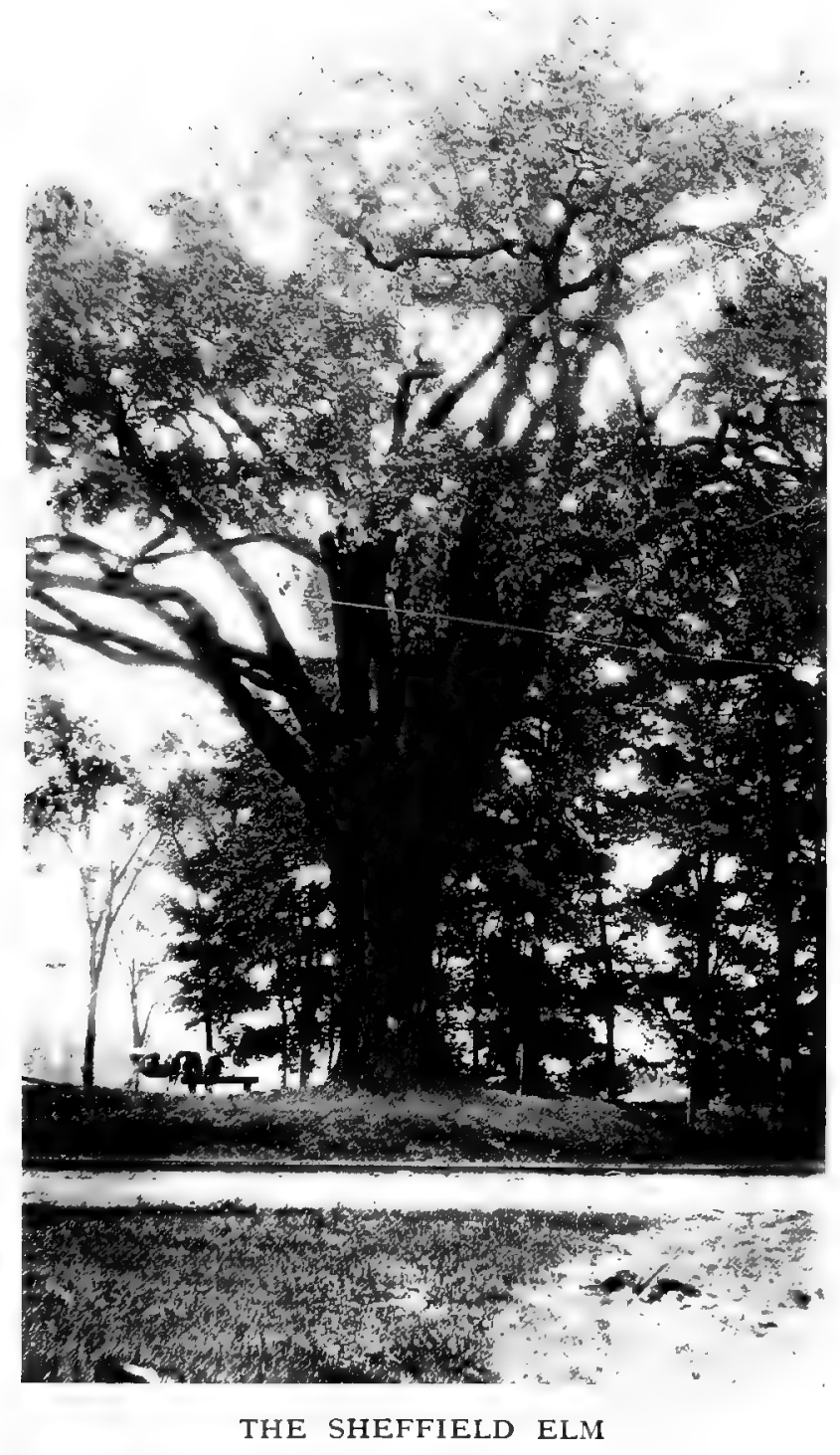



THE SHEFFIELD ELM

continues to produce a strong, graceful and pleasing appearance.

Looking back over a period of seventytwo years we find that "the great Sheffield EIm had, in 1844 , at the ground, a girth of twenty-two feet six inches; at two feet, eighteen feet six inches; at three, sixteen feet nine inches; at six, sixteen feet seven inches, above which it rapidly enlarges, and divides at ten or twelve feet into three large branches which soon subdivide. Its spread westward from the center is forty-nine feet six inches, and it is nearly equal on every side; height sixty or seventy feet." 1

At least three and a half feet had been added to these measurements in July of 1916. The three-foot circumference had increased to twenty feet and three inches, and the six-foot circumference to nineteen feet and seven inches. At breast height the tree was nineteen feet and three inches. The spread westward was fifty-four feet and the height eighty-two feet.

${ }^{1}$ Emerson, "The Trees and Shrubs of Massachusetts," vol. 2, p. 328.

[95] 
THE HISTORIC TREES OF MASSACHUSETTS

The historic traditions are even more interesting than the measurements. "The old elm" was standing when the town was settled $(1725-6)$ and an Indian trail leading into Connecticut passed near its trunk. There is a story to the effect that this trail was marked on either side by numerous apple trees which sprang from seeds dropped by the Indians in their wanderings.

A little to the southeast of the tree the frrst settler of Sheffreld, Mathew Noble, camped for a time with his daughter. They came on horseback from Westfreld, and the young lady, anticipating great cold, brought with her a feather-bed. At one time town meetings were held under the tree, and at another yearly town picnics were in vogue. The maple trees planted in the near vicinity of the elm were for the purpose of producing more shade for the picnickers. A local poet has written of the tree, setting forth some of its early Indian traditions.

Unfortunately, Washington, who brought into prominence so many of the trees of New England, passed this one by. But in this [96] 


\section{THE SHEFFIELD ELM}

connection it may be said that he once passed over another road not many miles distant, on his way to Salisbury and Egremont; and an ancient willow is still pointed out as the spot where he watered his horses. 


\section{CHAPTER XXI \\ DEERFIELD TREES}

Happy are they and charmed in life Who through long wars arrive unscarred At peace.

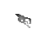
Herman Melville

THE name Deerfield suggests, to the average New Englander at least, all manner of things historic; and one glimpse of the main street of this town, with its quaint houses and the arching branches of its trees, is sufficient to establish in any visitor's mind, a never-to-be-forgotten picture. In the writer's opinion, one of the highest tributes which can be paid to a New England town is this - that it compares favorably as to beauty with "OId Deerfield."

If all of the Iarger trees should be removed, the old houses, many of which were built during the time of frerce struggle with the Indians, would still lend their enchantment [98] 


\section{DEERFIELD TREES}

to the locality. The preservation of the arts of weaving and basketry, practiced by those brave women who were the wives of the pioneers and the mothers of their children, constitutes another marked characteristic.

But the finishing touch of beauty is to be found in the spreading elms, the maples and the buttonwoods. They blend into the picture as they do into the whole history of the settlement. Standing at the head of the street as one approaches from the direction of Greenfreld, is a huge elm, seventeen feet in circumference and one hundred feet in height. This tree was without question standing here when Capt. Lothrop and his band of young men, the heroes of Bloody Brook Massacre, passed by. And from this point, on to the other end of the town, trees equally as old may be seen.

It is difficult to select a single tree, which, from aIl standpoints, may be considered as representative of the historic trees of Deerfreld. But since the great "Willard EIm," which stood in the northeast corner of the old-time barricade, is no longer standing, the

[99] 
THE HISTORIC TREES OF MASSACHUSETTS

honors may perhaps justly be divided between the buttonwood in front of the academy, and the eIm on Albany road.

The buttonwood is now eighteen feet in circumference, and one hundred feet in height and spread. It stands within the bounds of what was once the enclosure of the fort which was built in 1689 , and which remained until 1758. If size is any test of a tree's age this buttonwood was standing at the time of the Indian wars, for its circumference is larger than that of the Charlemont buttonwood (under which the pioneers slept in $174 \mathrm{I}$ ) by about two feet.

Many thrilling events took place within a radius of fifty yards from the spot occupied by the tree. Almost within reach of its shadow stood the "Old Indian House," built by Ensign John Sheldon in I698, and the Stebbins house, where, on the 29th of February, 1703-4, "seven men, besides women and children, held two hundred soldiers and one hundred and forty Indians at bay (under a French officer of the line) for three hours." 1

$[100]$

1 From inscription on monument. 


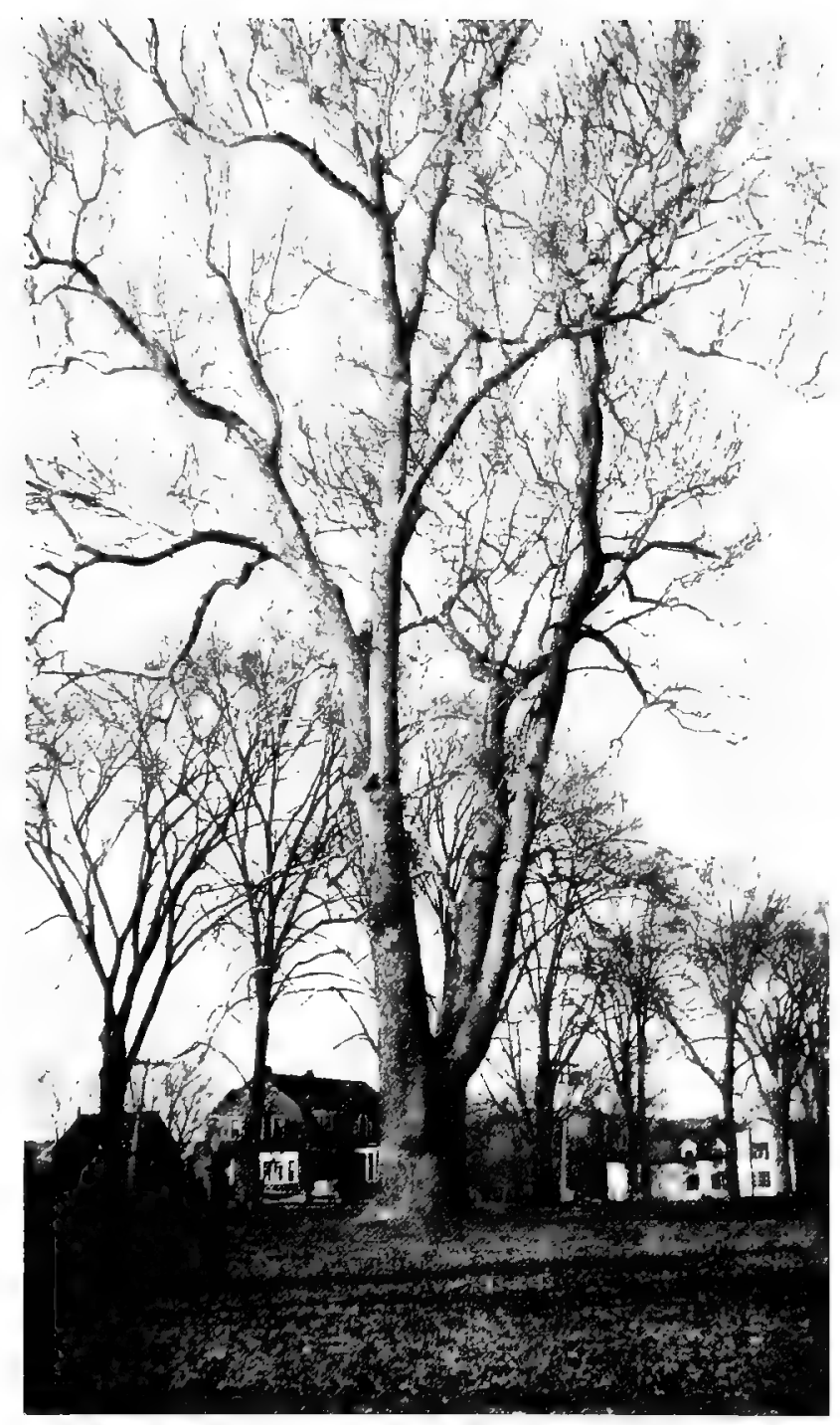

THE DEERFIELD BUTTONWOOD 


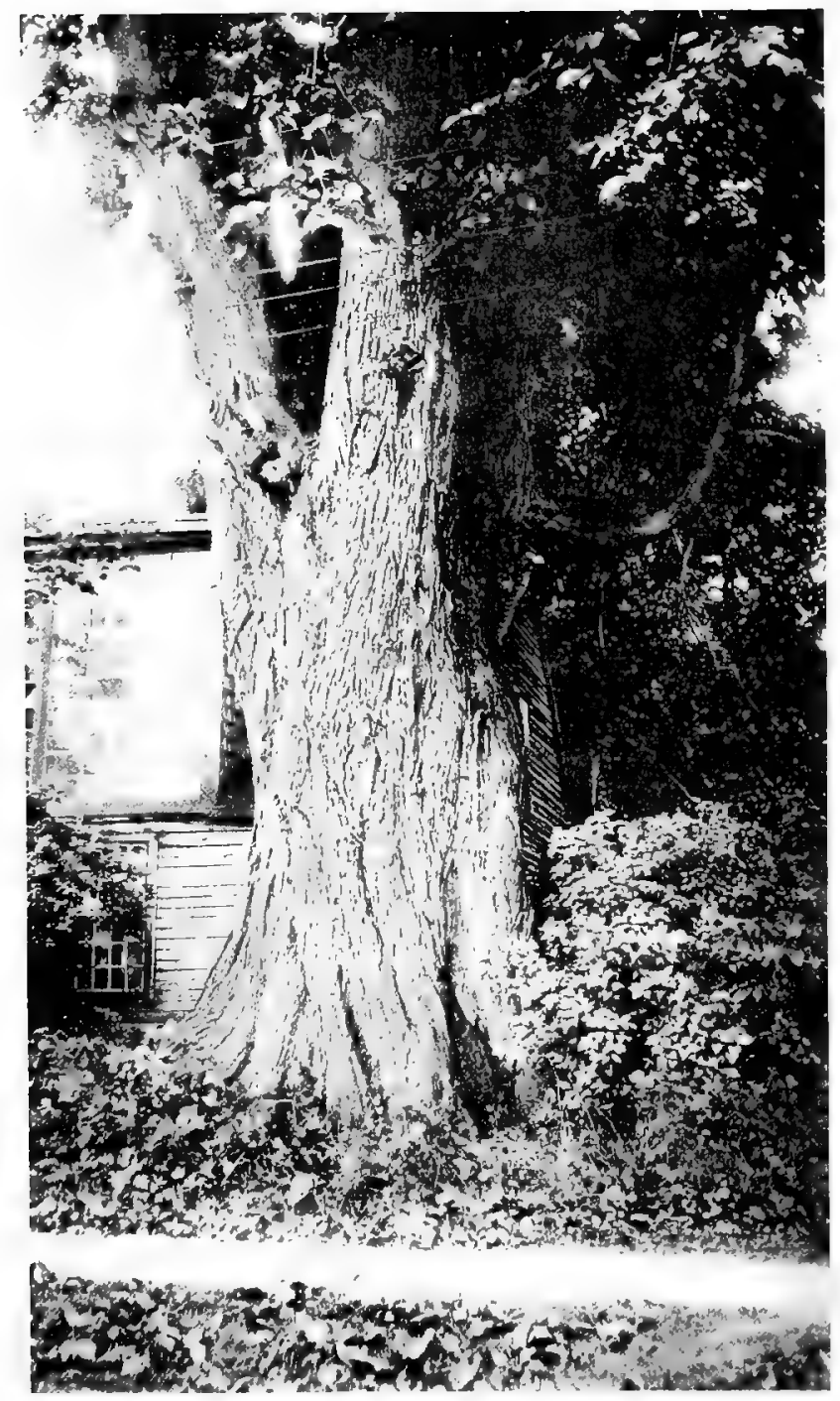

"THE ELM BY THE LITTLE BROWN HOUSE" DEERFIELD 


\section{DEERFIELD TREES}

In connection with the elm tree on the Albany road it is worthy of note that the Indians usually led their captives past this tree to a ford in the river, and thence to the Mohawk trail. The tree is known as "the elm by the little brown house." Thickly growing bushes and vines conceal its huge abutments, which stretch out on each side of the tree to a distance of seven feet. In girth this tree qualifies as an eIm of the first class, being twenty feet in circumference; the height is eighty-two feet, and the spread one hundred feet. With the exception of a few dead branches the tree appears to be in good health.

Strangely enough, there is hardly a spot in historic Deerfield marked by a monument which is not also marked, at no great distance, by an old tree; and one ponders, as he reads the various inscriptions, upon the number of living trees that were witnesses of the events commemorated by tablets of stone.

The country to the north and south of Deerfield is dotted with many beautiful [IOI] 
THE HISTORIC TREES OF MASSACHUSETTS

trees. There are several rows of ancient sugar maples along the road to South Deerfreld, while at Greenfreld, elms abound in large numbers, the most conspicuous being those in front of the library and the post office.

[ 102$]$ 


\section{CHAPTER XXII}

\section{THE CHARLEMONT BUTTONWOOD}

In the outskirts of the village,

On the river's winding shores,

Stand the Occidental plane-trees,

Stand the ancient sycamores.

Wbittier

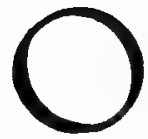

NE of the most picturesque spots on the "Mohawk Trail" may be found in the westerly portion of the little town of Charlemont, just beyond the old covered bridge which crosses the Deerfield River. At this point a buttonwood tree stands on the side of the slope a few feet above the road, and leans slightly forward as if to protect a spring of sparkling water near its base.

Here the first pioneer settler of the township slept when he came to take possession of the land which he had purchased for himself and his family; and not far away, on the side of the hill above, he finally perished at the hands of the Indians.

$$
\text { [ } 103]
$$


THE HISTORIC TREES OF MASSACHUSETTS

Captain Moses Rice, to whom belongs the honor of establishing the settlement, was a native of Sudbury. He married Sarah King in that town, Nov. 16, 1719, and their first child, Samuel, was born there Aug. I0, I720. Soon after, the family removed to Worcester, where the remaining children, six in number, were born. While at Worcester Captain Rice commanded a company of cavalry, and in 1724 was posted with others at Rutland, Mass., in a garrison commanded by Captain SamueI Wright.

His selection of Charlemont as a frontier home came about through a speculative enterprise on the part of the town of Boston. The Boston Township No. I, as it was called, comprised over 23,000 acres, and finally passed, almost entire, into the hands of two men. From one of these, who had acquired the power of attorney, Captain Rice bought 2200 acres, on the 23rd of April I74I, and came with his family in 1743 to take up life on the frontier.

Some time between the purchasing of the land and the coming of the Captain's [104] 


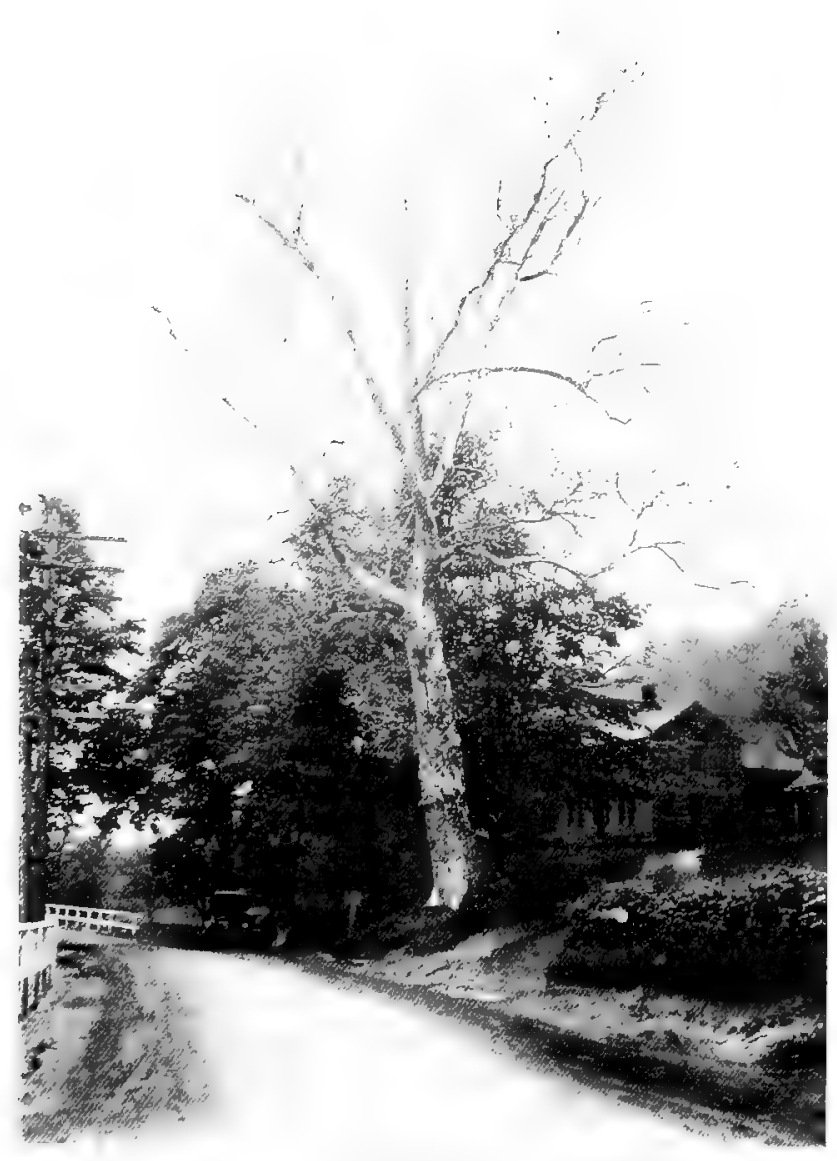

THE CHARLEMONT BUTTONWOOD 
' 
family, he visited his property in company with his sons, for the purpose of clearing a portion of land for meadow, and building a house. This journey gives us the basis in history for the part which the buttonwood plays in the story. A statement has been handed down by Sylvanus Rice, son of the Captain, to Mrs. Fuller, his daughter, a Iater inhabitant of Charlemont, that "he had slept under the Buttonwood tree when there was not another white person in town." ${ }^{1}$

In spite of the bitter struggle which began in 1744 between the British and French, in which the Indians took an active part, Captain Rice and his family remained in their exposed position unmolested until August, 1746, and their house was a favorite stopping place for the soldiers and wayfarers on the border. On the 20th of August 1746, Fort Massachusetts was invested by the French and Indians, and Captain Rice moved his family to Rutland just in time to avoid a massacre. Upon his return he found his

1 From Joseph White's "Charlemont as a Plantation."

$$
\text { [ } 105]
$$


THE HISTORIC TREES OF MASSACHUSETTS

house burned and his property destroyed. He repaired to Rutland for three years but returned at the end of that time and rebuilt his house. Another was erected on the meadow for his son.

Other settlers arrived at this time, and the Rice family, together with the Taylor and Hawks families, developed prosperous frontier settlements. Peace prevailed so Iong as the treaty of Aix-Ia-Chapelle was in force. But the three pioneer families lived in a state of preparedness during the period, and fortified their homes against future attack. When the storm finally broke it carried off Captain Rice; but the settlement was not destroyed, and prompt action on the part of the Province prevented a recurrence, and confined the French to their own territory further north.

The thrilling events which resulted so disastrously for the family of Captain Rice occurred within sight of the old buttonwood. The tree stands between the site of the first attack and that of the Captain's final struggle and fall.

[1 06$]$ 


\section{THE CHARLEMONT BUTTONWOOD}

"On Wednesday morning the IIth of June 1755, Captain Rice, his son Artemus Rice, his grandson Asa Rice - a boy nine years of age - Titus King, Phineas Arms and others, went into the meadow which lies south of the present village road ... for the purpose of hoeing corn. Captain Rice was ploughing and the boy riding the horse. The others were engaged in hoeing, except one who acted as sentinel - passing through the freld ... with musket in hand, while the firearms of the others were placed against a pile of logs near the western brook. ... Meanwhile a party of six Indians, as tradition informs us, having carefully observed their victims from the neighboring hill, stole cautiously down the western brook; and concealed by the thick brush-wood upon its banks, watched till the working party were ... farthest from their firearms, when they suddenly frred and rushed upon the defenseless party. Arms fell dead in the corn-freld; Captain Rice received a severe wound in the thigh and was taken prisoner, together with the Iad, Asa, upon the horse,

[107] 


\section{THE HISTORIC TREES OF MASSACHUSETTS}

and Titus King, a young man, and a relative of Captain Rice. Artemus Rice escaped, after a hot pursuit, and reached Taylor's fort at noon. The Indians ... withdrew with their captives to the high plain. Here the wounded man was left alone, with a single savage, to meet his fate. After a fearful struggle he fell beneath the tomahawk, and was left, scalped and bleeding, to die. Late in the day he was found yet alive, and was brought to his son's house, where he expired in the evening. The other prisoners were led to Crown Point and thence to Canada. The Iad was ransomed;... King ... at length returned." 1

On the slope of the hill there are standing at the present time several very old headstones which mark the graves of Captain Rice, his family, his grandchildren and Phineas Arms. The two oldest monuments are of slate, and time has almost obliterated the records. With the help of a putty-knife and a magnifying glass the following inscriptions were deciphered:

1 White, "Charlemont as a PIantation."

[ 108 ] 


\section{THE CHARLEMONT BUTTONWOOD}

IN MEMORY OF CAPT. MOSES

RICE, WHO WAS KILLED

BY THE INDIANS IN THIS

PLACE, JUNE YE IITH,

1755, IN XE 6IST YEAR OF

His AGE, AND LIES AT THE RIGHT HAND.

IN MEMORY OF MR. PHINEAS

ARMS, WHO WAS KILLED BY THE INDIANS

IN THIS PLACE, JUNE YE IITH, 1755,

IN YE 24th YEAR OF HIS

AGE, AND LIES AT THE LEFT HAND

SACRED TO THE

MEMORY OF DEAN AARON

RICE AND FREEDOM HIS WIFE,

WHO, HAVING SUSTAINED THE

HARDSHIPS OF AN INFANT FRONTIER

IN TIME OF WAR, HAVING

REARED A FAMILY OF ELEVEN CHILDREN,

NINE OF WHOM HE INTERRED IN THIS

GROUND, AND LIVED TOGETHER IN

HAPPY WEDLOCK 54 YEARS,

DEPARTED THIS LIFE THE FIRST, DEC. 2, I 808 , AGED 84

YEARS \& THE OTHER, SEPT. I5, I 809 ,

AGED 79. AND THEY WERE BOTH

RIGHTEOUS BEFORE GOD, WALKING IN

ALL THE COMMANDMENTS AND ORDINANCES

OF THE LORD BLAMELESS.

These graves were exhumed some years ago, and the bullet which killed Phineas Arms was found lodged in his skuIl. It may be seen at the historical rooms in Deerfield. In the midst of the crumbling slabs of slate stands a large granite monument of more [ 109] 
THE HISTORIC TREES OF MASSACHUSETTS

recent origin, intended as a permanent memorial to the first settler of Charlemont.

But more frtting than any other, while it remains, will be the living monument of the buttonwood tree. Its topmost branches reach to a greater height than the graves on the hill, for the tree is ninety-eight feet high. Beneath the branches, which spread themselves over eighty-frve feet of space, passes the "trail"; and near the massive trunk, sixteen feet in circumference, still bubbles the crystal spring water. 


\section{CHAPTER XXIII \\ THE SUNDERLAND BUTTONWOOD}

It is a sense of kingly isolation,

Of rough beauty and enchanting grace,

Proclaiming from the earliest creation

The power and pride of race.

Tracy Robinson

CUNDERLAND possesses a gigantic "Old Buttonwood" (in place of the conventional "old elm" of many New

England towns), the largest described in the present collection, and the Iargest, doubtless, in Massachusetts. While surpassed in size by a few elms, this old tree holds an enviable position, and justly so, for in point of size the species stands preëminent among the trees of the New England forest.

The great limbs, stretching upward for a hundred feet, more or less basket-shaped, and spreading to an equal distance, are plainly visible from Sugar Loaf Mountain, and from several points along the highway leading north. Their characteristic color

$$
\text { [ I I I ] }
$$


stands out conspicuously against the green background of other trees. More marked than any other particular feature is the ponderous trunk. It reminds one of an elephant. The girth at breast height is 20 feet, 6 inches, and it is very nearly uniform to the dividing point, which comes at about fifteen feet.

Historically, the tree ranks with those of Deerfield, although no battles are actually known to have taken place in its immediate vicinity. The train-band men used it as a meeting place, and, by reason of their activities, placed it on record as a celebrated tree. Among the amusing questions asked by the uninitiated of the present day is that of the man who desired to know "who whitewashed the branches?"

In connection with this Iocality two elms are of interest on account of their great size. They are standing, close together, near the other end and on the opposite side of Main street, and the larger of the two is nearly equal in girth to the old buttonwood. 


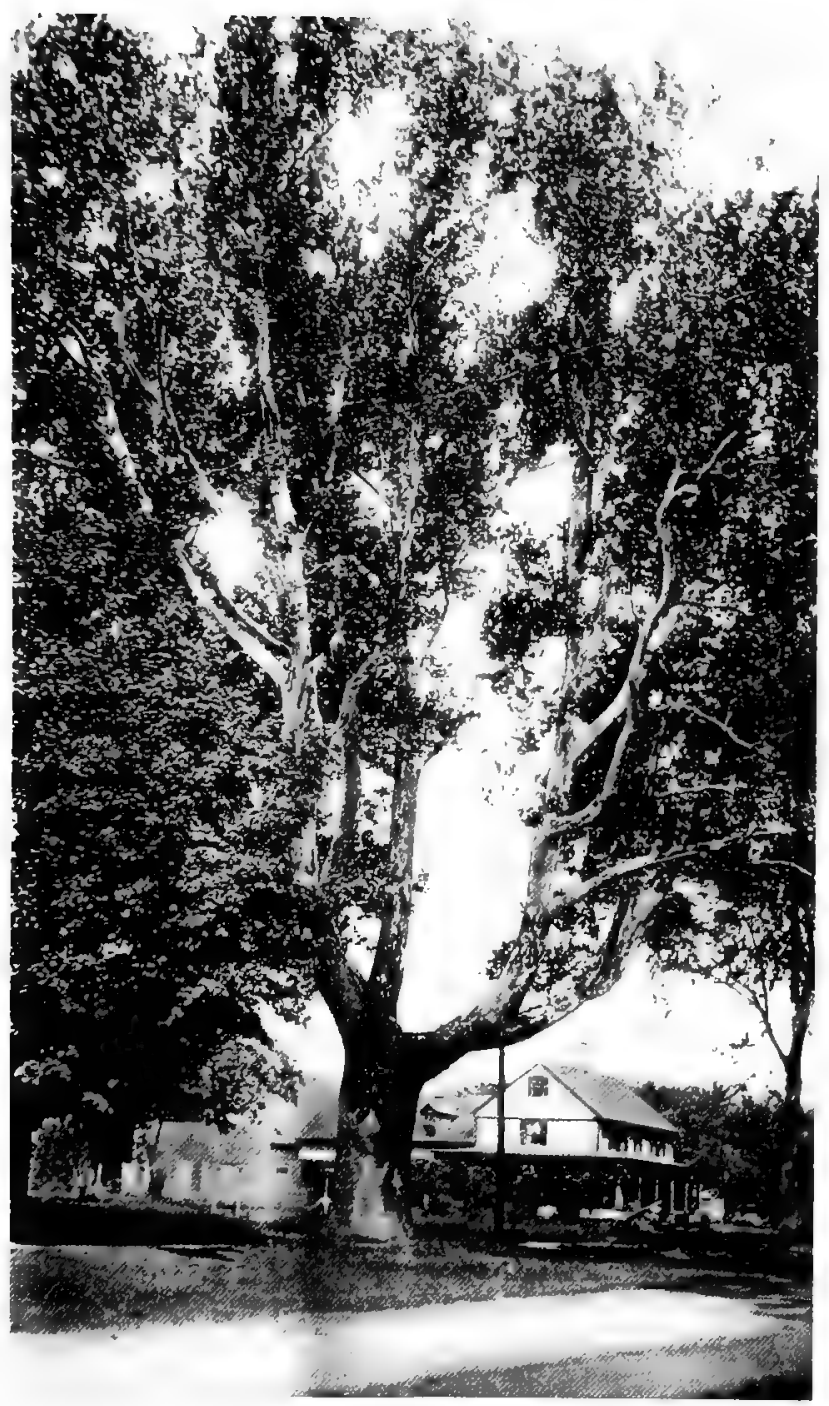

THE SUNDERLAND BUTTONWOOD 

CHAPTER XXIV

THE OLIVER WENDELL HOLMES PINE

What didst thou sing of, thou melodious sprite?

Pine forests, with smooth russet carpets spread,

Where e'en at noonday dimly fades the light,

Through gloomy blue-green branches overhead.

Frances Anne Kemble

THE glory of the Berkshires is in its mountains and its trees. Standing on any one of the many peaks in autumn you are impressed with the vast wealth of color stretching for miles about you, and realize that every variety of tree peculiar to the Great Northern Forest is growing there before your eyes. You recall passing elm after elm, huge and towering, in Great Barrington, Stockbridge and Lenox, and, passing along the winding roads, among the valleys and around the Iakes, you discover new and unfamiliar shapes and colors where distant species have been brought in to add to the already beautiful picture. Why ask for historic trees in this land where 
THE HISTORIC TREES OF MASSACHUSETTS

people play and rest and work? Is it not enough that they are beautiful, and that they are unlimited in quantity?

And yet, as you walk along the old road to Lenox, you will mark in a wide sweep of Iawn the lone and superb pine so much Ioved by Dr. Holmes. "Canoe Meadow" was a carrying place of the Indians, and held everything that he most delighted in. His house stood on the soil owned by his greatgrandfather, Jacob Wendell, Colonel of the Ancient and Honorable Artillery Company. Here were half a hundred acres of forest trees, some of them probably five hundred years old; above their foliage the Berkshire Hills reared their silent heads, and the Housatonic River made its course in a thousand fantastic curves through the meadows. ${ }^{1}$

Here at last is an historic pine, one of the favorite trees of a noted personage, and an excellent representative of our great New England conifer.

\footnotetext{
${ }^{1}$ Abbott, "OId Paths and Legends of the New England Border."

[I I I 4 ]
} 


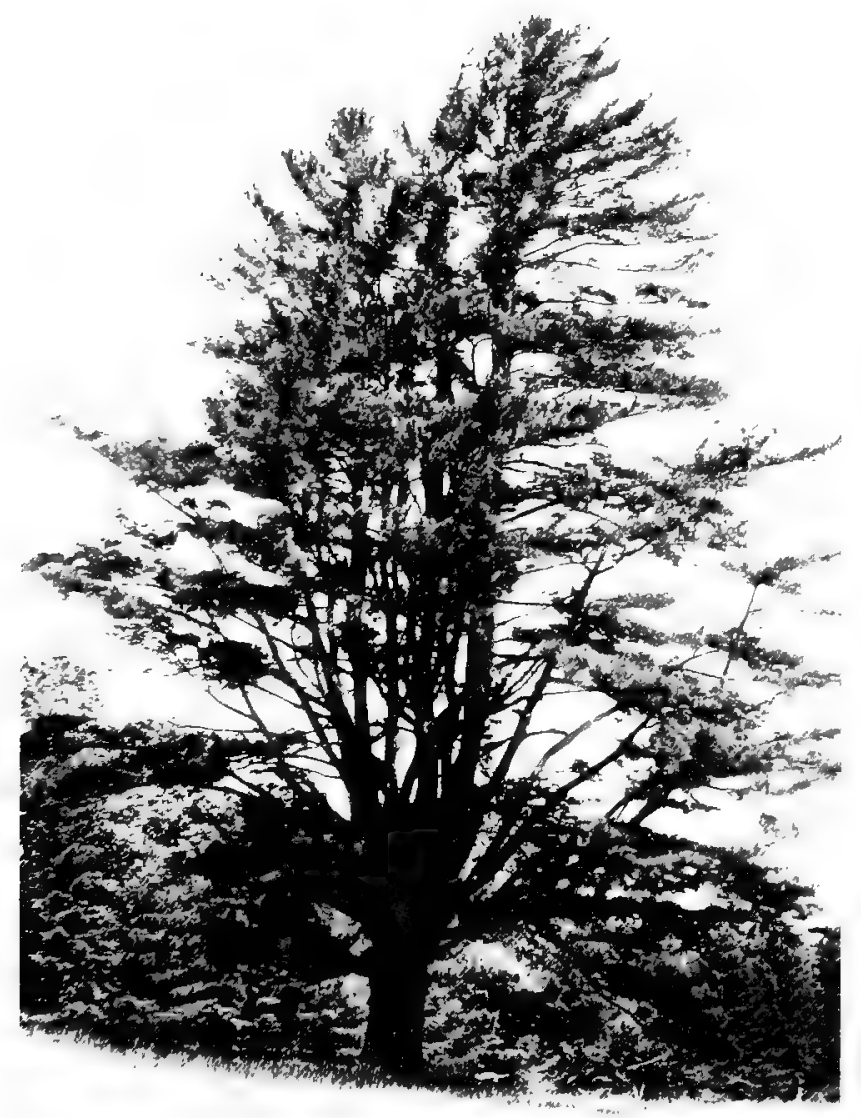

THE OLIVER WENDELL HOLMES PINE 

THE OLIVER WENDELL HOLMES PINE

You measure its trunk and find that it is I6 feet 4 inches in girth; you wonder at the great depth of its shadow and find that the spread of the branches is nearly 90 feet; and you look upward to its topmost branch and find, if you have a measuring instrument, that it is 97 feet from the ground.

There may be a larger white pine than this somewhere in Massachusetts; but where shall we look for it? In the few remaining stands of virgin timber some trees remain whose height reaches one hundred feet and over, but these are Iumber trees, having a long, tapering bole, and only a wisp of needles at the top. Such a tree was the gigantic pine, 17 feet in circumference, that once stood near the turnpike road between Reading and Andover in Essex County, and which was spared by the Iumberman because it was the largest tree on the Iot. Even in the practice of forestry the pine is protected only for what it will yield in less than seventyfive years as a timber crop, and pines of large girth are now few and far between.

The Pittsfreld pine is still apparently sound [ I I I 5 ] 
THE HISTORIC TREES OF MASSACHUSETTS

in spite of its great size and age. Dr. Holmes has not described it as one of his "tree wives," nor "gilded with a rhyme its household name," but it remains as a heritage to us, like his portrait of Dorothy Q.,

"And lives untroubled by woes and fears

Through a second youth of a hundred years."

[ II6] 


\section{CHAPTER XXV \\ OTHER WELL-KNOWN TREES}

Hath reared these venerable columns, thou

Didst weave this verdant roof. Thou didst look down Upon the naked earth, and, forthwith rose All these fair ranks of trees.

Bryant

MONG the largest and most beauti-
ful trees in all Massachusetts are
those noble old monarchs of the forest which, by reason of sheer excellence alone, have established for themselves a permanent place in the list of truly great trees. They need no specific event to render them historic; they are in themselves historic by reason of their age, size and refining influence upon mankind.

A book written entirely in the spirit of this suggestion might well include every extraordinary specimen of tree in the Commonwealth. The present volume was, however, originally intended to include only 
THE HISTORIC TREES OF MASSACHUSETTS

"historic trees" in the established sense of the term, and for this reason a separate chapter is added here, in which the "unheralded and unsung" may have a place, through the medium of their worthy representatives.

\section{Berkshire County}

The preceding chapter, dealing with the Oliver Wendell Holmes Pine, left the reader in the far end of the state, after an imaginary trip from sea-level west. It now remains for us to journey back hastily, admiring an individual tree in one place, a group in another, and to those that must of necessity be left behind, be this the parting word -

$\mathrm{O}$, flourish, hidden deep in fern,

Old oak, I love thee well!

A thousand thanks for what I learn

And what remains to tell.

There is a stately old elm on the back road to Stockbridge, a few miles out of Lenox. This tree is $16 \frac{1}{2}$ feet in circumference, 97 feet in height and 87 feet in spread. Tradition credits it with having sheltered with its branches a meeting of Revolutionary generals about 1776 , but there seems to be no [ II 8 ] 
OTHER WELL-KNOWN TREES

recorded proof of this assertion. The shape of the tree is somewhat unusual, being that of a vase more or less broadened near the base; and it stands not far from one of the most beautiful of Berkshire views - a point commanding a view of Greylock on the one side and Mt. Everett on the other, with just the turning of one's head.

In the northern Berkshires the most typical tree is the elm standing near the roadside as you go from South Williamstown to Hancock. This elm is $17 \frac{1}{2}$ feet in circumference, 94 feet in height and 115 feet in the spread of its branches.

In the town of Savoy there is a remarkable curiosity in the form of a spruce tree only five feet high, but possibly a century old. Frank N. Blake's article and photograph in the Springfield Republican of May 24, I9I4, frrst introduced the tree and boulder in which its roots are embedded to the general public. In a letter received from $\mathrm{Mr}$. Blake in May, I918, the following description was given:

"There is a spruce tree near South Pond, 
THE HISTORIC TREES OF MASSACHUSETTS

Savoy, growing on a rocking boulder; it is five feet high, and an old resident, born near by and living there until recently, told me he remembered it as a boy as being the same in appearance over fifty years ago. The boulder I measured and estimated the weight to be twenty-nine tons, yet it is so nicely poised that I could rock it with the pressure of one finger. The tree grows in a fissure and has no connection with the earth, and my impression is that it must suffer from dry weather and cold in winter; no wonder that it does not grow - the wonder is that it lives."

\section{Hampden County}

We descend to the region of Springfreld, where most of the big trees have already been sought out and described in the preceding chapters, and we pass on to the towns about Wilbraham. Here a whole day might be spent in going from one to another of the aged Iandmarks. A list submitted by Henry I. Edson, forest warden at North Wilbraham, includes no less than a score of super-trees. The most beautiful of all [120] 
is the BaIdwin Maple at North Wilbraham; the largest of all is a chestnut 22 feet in girth standing on the Iand of Addison Bennett about a mile and a half south of North Wilbraham on the Glendale road; and the one tree on the list that most nearly approaches the historic is the "mile tree" at Wilbraham Green, where, in times past, the men of the locality were assembled for military training. There is a big elm in town and several old oaks, a very old hickory and two notable apple trees. One of the Iatter is the so-called Hancock Greening. The family whose house stood by this ancient tree claims descent from the brother of Governor John Hancock.

\section{Worcester County}

Passing on to the middle of the state we find two very old elms, each of which has laid claim to the title of Central Tree. A glance at the map will show that the geographical center of the state lies somewhere within the confines of the townships of RutIand and Paxton, and, as the two elms are 
THE HISTORIC TREES OF MASSACHUSETTS

the largest to be found in their immediate vicinity, each has been decorated in years gone by with a legend in token of its distinction. The pine board clinging to the trunk of the Paxton EIm is now old and weather-beaten and should of necessity be replaced with another, stating that the king is dead. The tree still stands, almost entire, with its columnar trunk I4 feet in circumference, and its branches towering into the sky 60 or 70 feet. The Rutland Elm clings tenaciously to life, but its most beautiful branches are gone and its visage is battered and warlike. The circumference at breast height is 12 feet and 4 inches. These trees have been patient in adversity, braving the cold winds of many winters in a place where proper treatment is expensive and difficult to obtain. They have served as an example of fortitude to many persons who have gone in quest of health to the high elevations on which they stand.

The town of Lunenburg lies within this upland district of the center of the state, and takes pride in two remarkable trees of [ 122 ] 
OTHER WELL-KNOWN TREES

advanced age. It was originally planned to devote a chapter to the old buttonwood near the band-stand in the town square, because of the tradition that this tree was planted on the $4^{\text {th }}$ of July 1776; but no substantial data were found by which it could be linked in immortal memory with the Declaration of Independence! The oldest inhabitant was at last appealed to, but his information may be summed up in the words, "I wa'n't here, so I don't know." The tree is not over I 2 feet in circumference. But the pride of the town, "Old King Arthur," a white oak that stands by the side of a country road a few miles out from the center of the town, was probably there some years in advance of the first pioneer settler. It is about 16 feet in circumference and spreads its branches over a space of about 90 feet.

On the northern border of Worcester County, at Royalston, a Iarge elm has Iong been standing on the top of a high hill. It is known, Iocally, as the "Sentinel EIm," and is a good example of its species growing on the higher slopes. 
THE HISTORIC TREES OF MASSACHUSETTS

The town of North Brookfield possesses several remarkable elms along the main street. One is exceptional, having a circumference of nearly twenty feet, and very broad shoulders where the branches emerge from the trunk.

In the town of Oakham there is standing a white oak from which the town seal was fashioned. While only eleven feet in circumference this oak is claimed to be very old, and has the added distinction of being almost perfect in its proportions. The location is a pasture along the road leading from Oakham to Coldbrook.

The Lancaster group, of elms, oaks and maples, has for many years held a leading place in the annals of great trees; but the great Lancaster EIm, once the largest tree of its kind in the State, is no Ionger standing; the famous Cunningham Maple and the Carter Oak are both in advanced stages of decay, and appear "Iike veteran warriors, beaten down in battle, bearing up their banners to the Iast." The Beaman Oak remains in all the glory of its strength, and is claimed to be the largest red oak in Massa[1 24] 


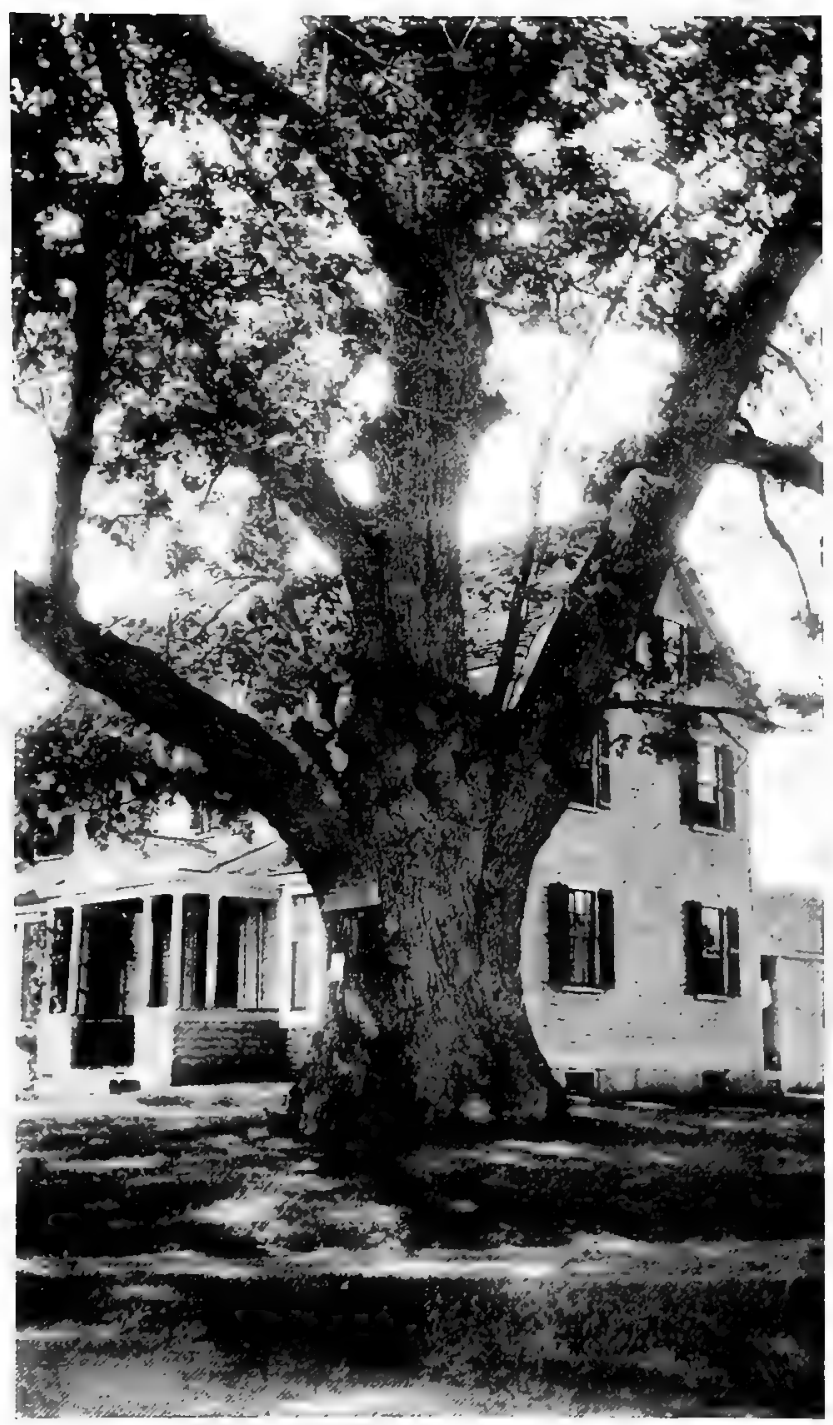

THE BEAMAN OAK 


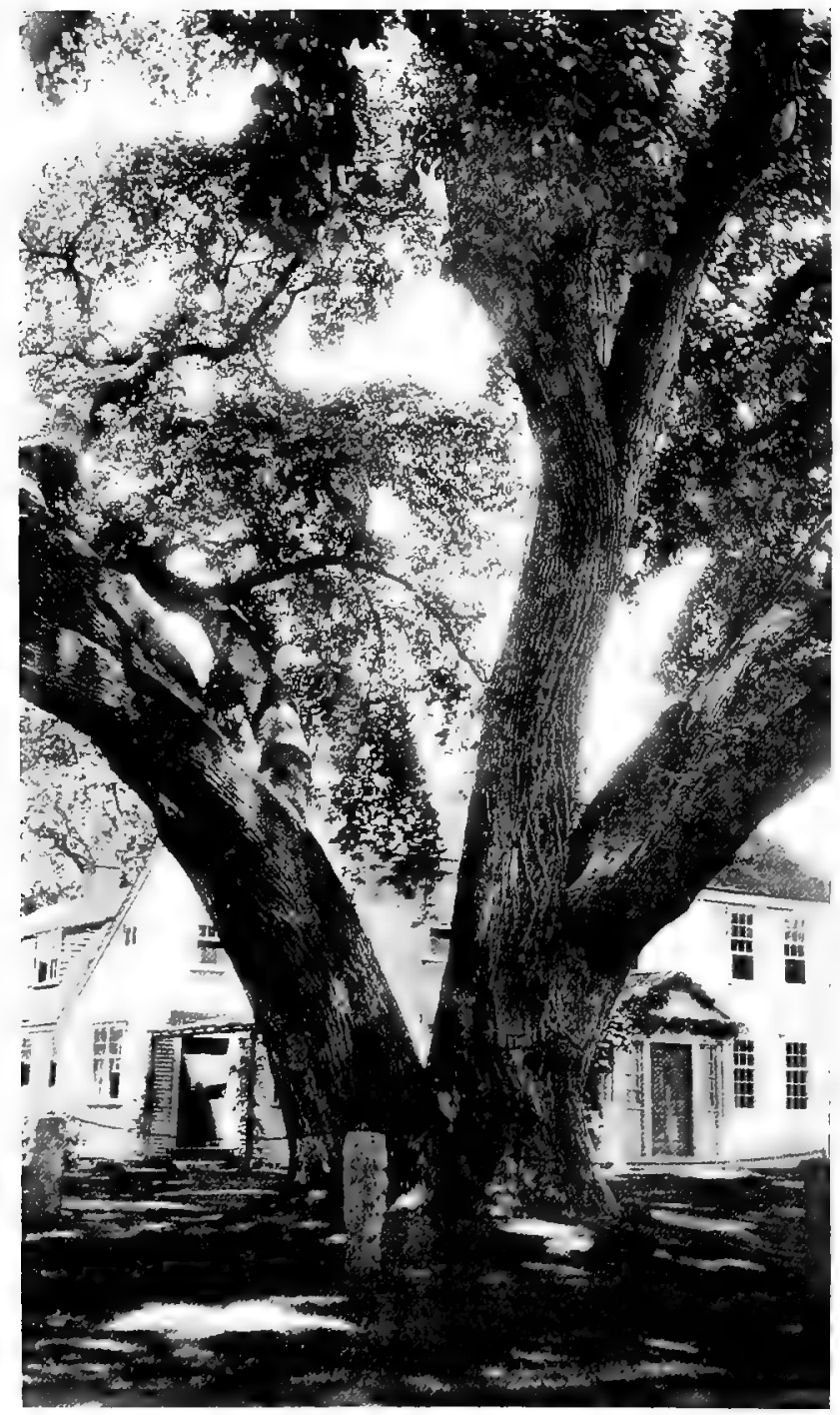

THE RUGG ELM 


\section{OTHER WELL-KNOWN TREES}

chusetts. It marks the place where Gamaliel Beaman, an early settler, built his house in 1659. The measurements are as follows: circumference at the ground, 29 feet; at breast height, 20 feet; at five feet from the ground, I9 feet, 9 inches; height, 75 feet; spread of branches, 90 feet.

\section{Middlesex County}

The Rugg Elm (also known as the Gates EIm) at Framingham, situated about two hundred yards from the turnpike road, between Framingham and Fayville near the grounds of the Country Club, is the largest elm herein described. If, indeed, it is a single tree, and not two trees springing from a common root system, it is without doubt the Iargest eIm to be found anywhere in New England. The circumference at one foot from the ground is twenty-eight and a half feet, and at about three feet from the ground the trunk divides into two parts, one of which, at breast height, is seventeen feet, and the other fourteen feet in circumference. Between these two trunks there is 
THE HISTORIC TREES OF MASSACHUSETTS

a peculiar woody formation, or "nubbin," which may at one time have been the beginning of a third section. It has been literally squeezed out of existence. At the point where the main trunk divides and this dwarfed formation emerges, the circumference is twenty-five and a half feet. The two gigantic trunks subdivide at about eight feet into three large branches each, and, in combination, form one of the most remarkable crowns that can be conceived of. The spread of the branches is one hundred and forty-frve feet, and the height of the tree is seventy feet. The age of the Rugg EIm has been variously estimated at from three hundred to four hundred years. Protected from severe storms by a sheltering rise of ground, it has succeeded in preserving all of its limbs, which, but for their supports, would rest for a portion of their length upon the ground. The owner of the tree, Mr. Dennett, has spared no effort to protect the landmark, and it has during recent years received the best of care and some assistance in the way of tree surgery. The work has been [1 26] 
OTHER WELL-KNOWN TREES

so skilfully done that no artifrcial effect has been added to the general appearance of the tree and it bids fair to last for another century.

The only tree in Massachusetts which, at maturity, has ever approached the Rugg Elm in the grandeur of its spreading branches is the elm which stands on the Knowlton farm in West Acton. This super-elm lost over half of its branches about three years ago, when they fell of their own weight in a very ordinary gale. Timely assistance would have preserved this tree for more than a generation. It has long been credited with possessing the greatest spread of any elm in this section of the country, and the remaining half section covers fully a hundred feet of ground. The largest $\operatorname{limb}$, which was shorn off and still lies where it fell, is II feet and 4 inches in circumference. It would seem as if strength had been sacrifrced for beauty, and as if a noble head had at last fallen from shoulders too weak to support it. The trunk is fourteen feet, eight and a half inches in circumference and thoroughly sound. The height of the tree 
THE HISTORIC TREES OF MASSACHUSETTS

is sixty-seven feet. Its earlier development was along much the same lines as that of the Lafayette Elm at Ware, described in another chapter. But the latter has laid a more permanent foundation in the form of a ponderous trunk, of which the Iargest branch is a continuation.

The towns of Weston and Wayland are rich in beautiful trees, at least one of which is connected, traditionally, with Washington and his escort, and their journey to Cambridge in 1775. This favored tree is a white oak, and stands on the side of the slope a little to the Ieft of the State road as one enters Weston from the east, and its branches extend over the driveway leading to the Winsor estate. The most conspicuous tree in Wayland is the eIm in the turn of the road at the eastern end of the town. It is a fine example of the oak-tree type of American eIm and has a spread of nearly roo feet.

The Waverley group, of twenty-frve white oaks, which for many years has been considered famous, under the name of "The Waverley Oaks," is composed of remarkably [128] 


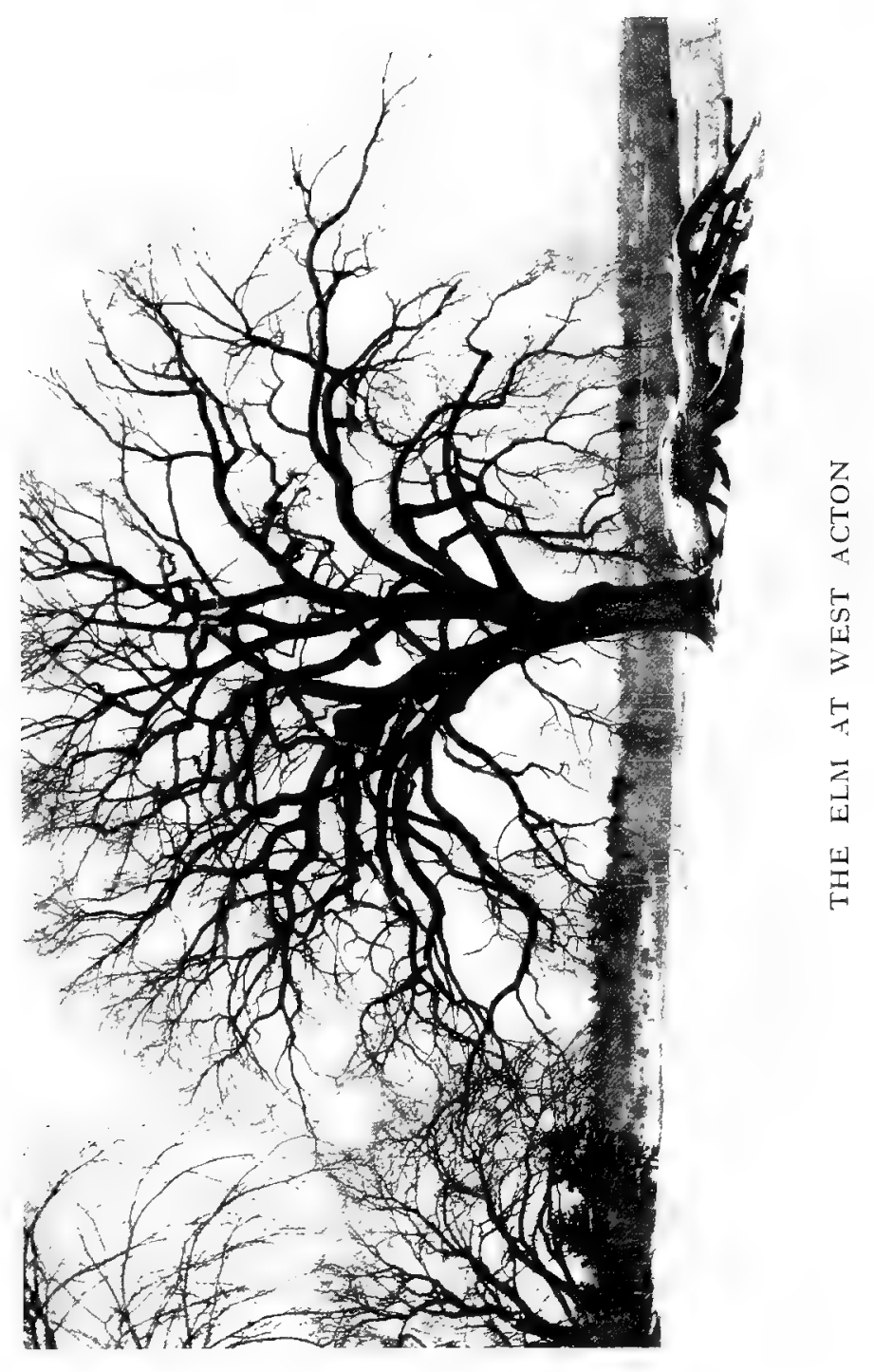




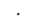


OTHER WELL-KNOWN TREES

large trees, and the "old giant" ranks with the greatest of white oaks. These trees are associated with James Russell LoweII and the "Vision of Sir LaunfaI." At the present time nearly all of the tops are "staghorned" and their beauty is rapidly passing. The splendid tree at the entrance to the park in which they stand is about the average size for the group and seems to be in better condition than any of the others. The circumference is fourteen feet, two inches, the height is sixty feet and the spread ninety feet.

The great white oak at Billerica, while not strictly historic, has witnessed the founding of that town, and Washington and other noted persons have passed beneath its shade. It is fifteen feet in circumference, sixty-frve feet in height and ninety feet in spread, and is decorated with the following inscription:

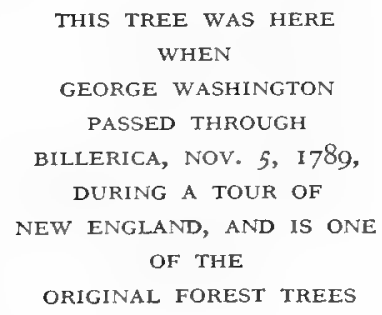


THE HISTORIC TREES OF MASSACHUSETTS

\author{
Extract from \\ Washington's Diary - \\ "Mr. Phelps accompanied \\ me from Andover througb \\ Billerica to Lexington. \\ A mile or two from Andover \\ you descend into a pine level, \\ pretty, sandy, and mixed with \\ swamps tbrougb whicb you \\ ride several miles till you \\ descend the beights on wbicb \\ the town of Billerica stands, \\ wbich is so pleasantly situ- \\ ated ro miles from Andover." \\ THIS INSCRIPTION PLACED HERE \\ BY THE \\ BILLERICA HISTORICAL SOCIETY, 1896
}

Among the towns in eastern Middlesex, just north of Boston, notably Medford and Winchester, there are many beautiful trees of all kinds. The two most remarkable specimens are the eIm near the railroad station in Winchester and the black walnut near Grove street in West Medford. The Winchester EIm is not among the largest of our famous trees, being only ten and a half feet in circumference, but no more beautiful tree may be found in this section. It has adapted itself to the conditions of our modern city streets and flourishes in the very center of [130] 


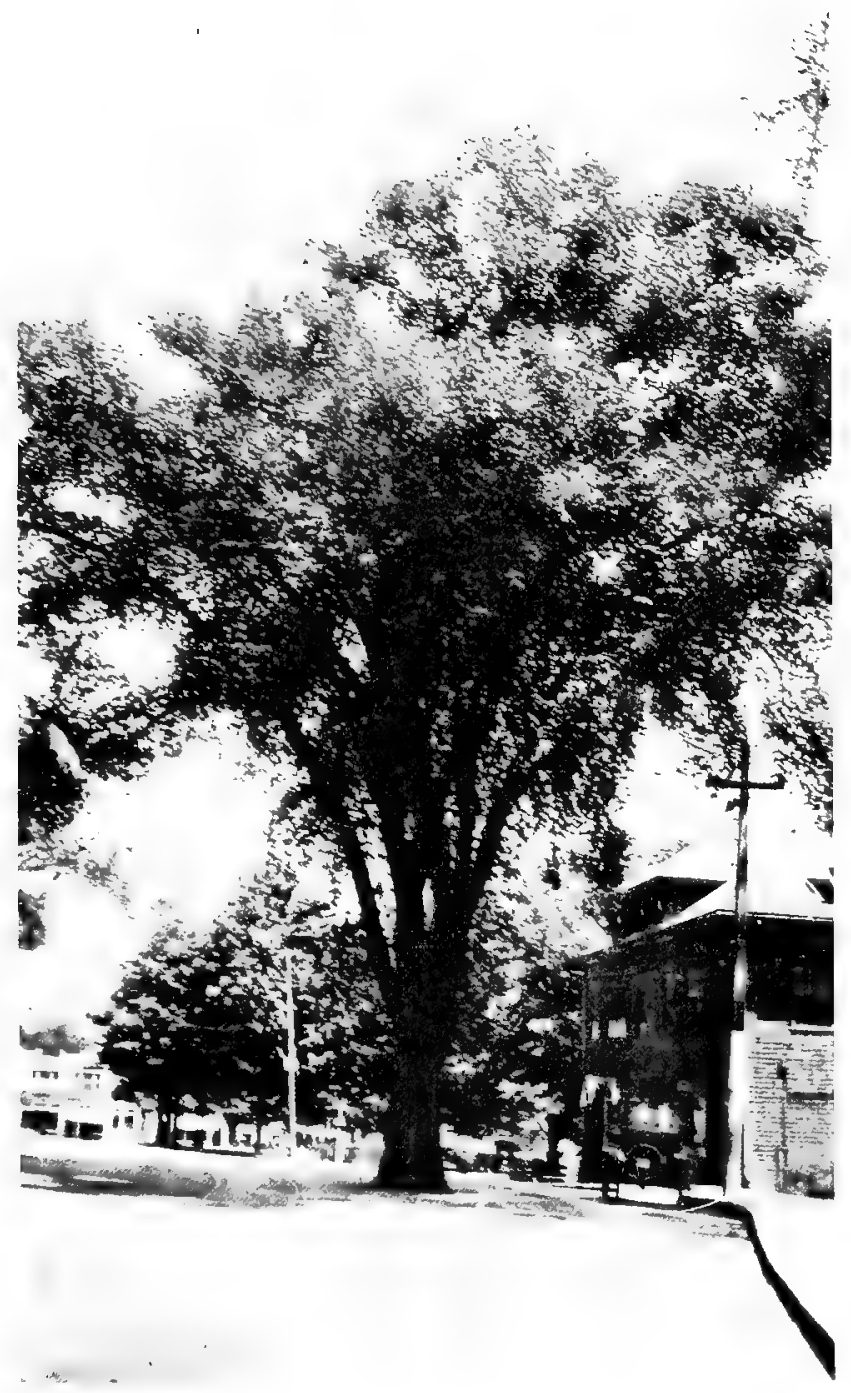

THE WINCHESTER ELM 


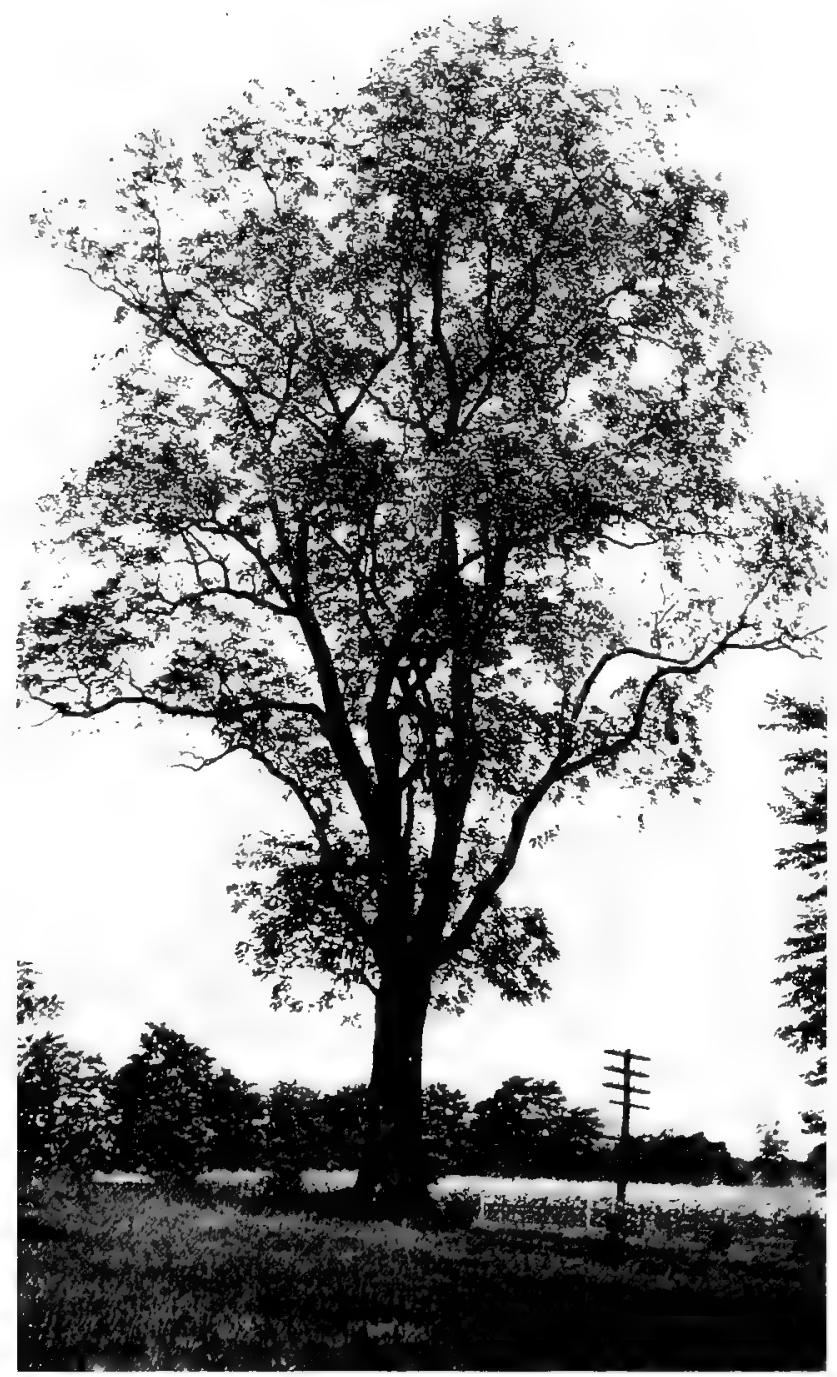

THE BLACK WALNUT AT WEST MEDFORD. 


\section{OTHER WELL-KNOWN TREES}

one of the main thoroughfares of Winchester. The black walnut at West Medford is fourteen and a half feet in circumference, eighty feet in height and seventy-frve feet in spread. There is some local history attached to it, the best summary of which may be found in a short article written by a suburbanite for the Boston Globe of June 22, 1918:

\section{ANOTHER LARGE TREE}

\section{Editor People's Column:}

There is a notably large black walnut tree at West Medford. A brief description of the tree is given on pages 500-501 of Charles Brooks and James M. Usher's History of Medford. According to that description in 1884 the tree measured 19 feet and 8 inches in circumference at its base and had a $\operatorname{limb}$ which measured 9 feet and 3 inches in circumference. For many years previous to the death, in 1799, of Thomas Brooks, his house - which long ago disappeared - stood in front of the tree. When Mr. Brooks' negro slave Pompey slaughtered his master's hogs he used to hang the carcasses on the above-mentioned large limb of the tree. The tree, notwithstanding its extreme age, seems to be still full of vigor, and apparently it is destined to live for a long time to come. The tree is east of and some 125 feet distant from that part of Grove st. which is a few rods north of the junction of that street and Jackson Road, being opposite to that part of the street which is skirted by a brick wall, still standing, which Pompey built in front of his master's house about 1765 . Of that brick wall, which, as well as the big black walnut tree, is quite a notable historical Iandmark, a picture is given on page il of "Medford, Past and Present," and on an unnumbered page facing 230 of "Proceedings of the Celebration of the 275th Anniversary of the Settlement of Medford." 
THE HISTORIC TREES OF MASSACHUSETTS

\section{Essex County}

A "splendid old wreck of an eIm" at North Andover, known as the Hubbard EIm, is the peer of Essex, and may be considered as a strong contender for the title of the largest elm now standing in Massachusetts. The dimensions fall slightly below those of the Rugg EIm, but if a distinction is made between elms having a single and those having a double trunk, this tree possesses the largest girth of them all. Though hollow it commands the greatest admiration and wonder, and its mighty abutments stretch out for several feet on all sides, as if inviting the beholder to step thereon and grasp the deep-furrowed bark in a fond embrace! On the ground about the tree lie several of the once powerful limbs in varying stages of decay where they have fallen. The complete picture produces in the observer the keenest of emotions, and he leaves it with regret, knowing that the time will not be long during which he may be permitted to gaze upon so mighty an elm. The circumference is twenty-four feet and five inches at breast [132] 


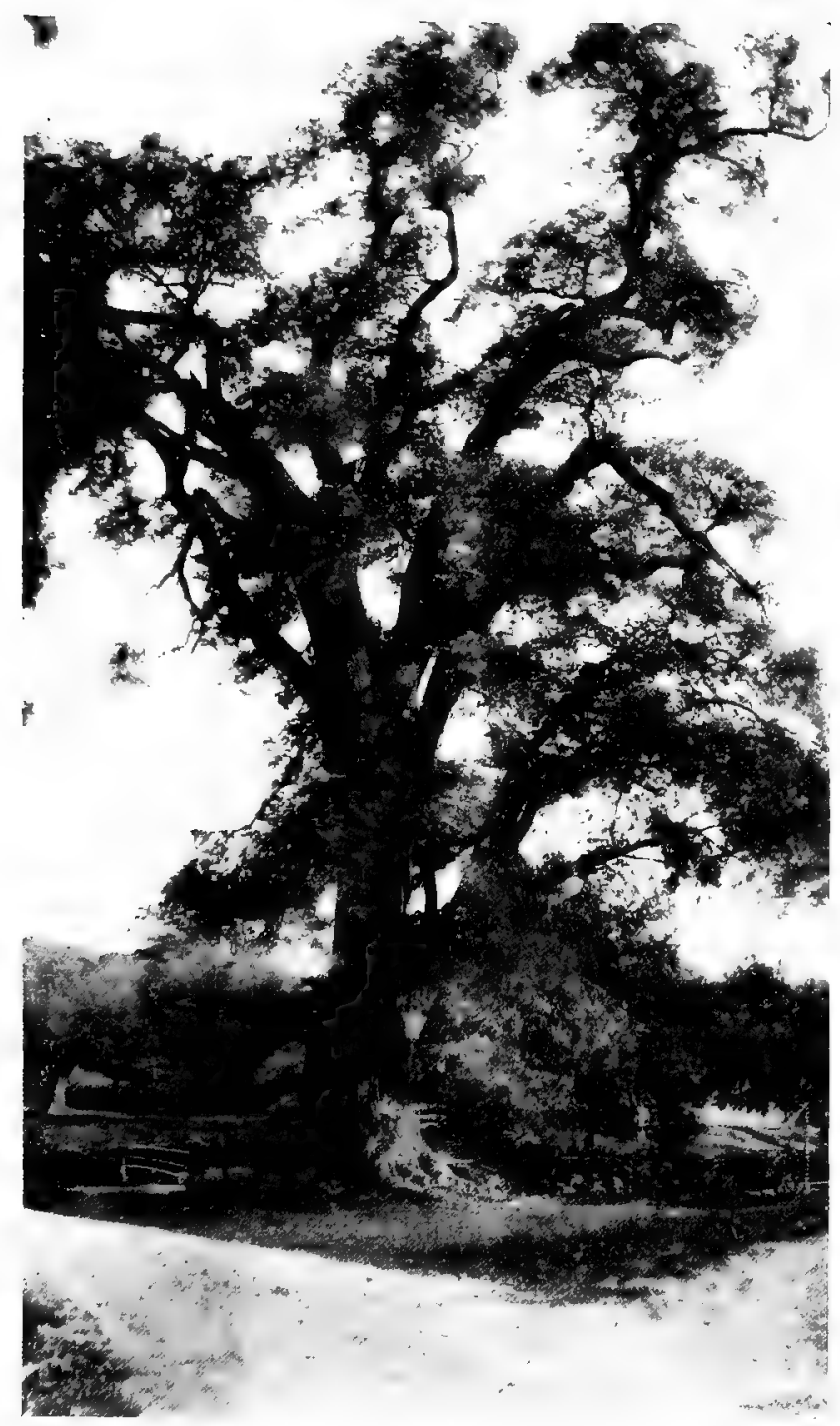

THE HUBBARD ELM 

OTHER WELL-KNOWN TREES

height, and the height is ninety-eight feet. The spread is not over sixty-five feet, probably a Iittle more than half of what it was before the beautifuI, Iong limbs fell to the ground.

A movement was at one time started, but came to no effect, to rejuvenate and preserve this tree by surgery. The tree would respond to treatment even now, and there is abundant precedent for so good a cause - for example the action taken by the Winthrop Improvement and Historical Association to perpetuate the memory of the old Gibbons Elm.

The Gibbons EIm stood near the dwelling of Major General Edward Gibbons, who was one of the fifteen men to whom Pullen Point was allotted in 1637 , and one of the founders of the Ancient and Honorable Artillery Company. When the 275th anniversary of the allotment was observed, in June, I9I2, a service was held in special honor of the elm tree which had witnessed so much of the history of the town of Winthrop, and which had grown so old as to render its removal 
THE HISTORIC TREES OF MASSACHUSETTS

imperative. Accordingly, some 3000 people assembled at one of the most remarkable gatherings ever held in honor of a tree. Charles Francis Adams was the orator of the day, and Denis A. McCarthy read a poem on "The Old EIm." The Ancient and Honorable Artillery Company then planted a new elm to take the place of the old.

\section{Norfolk County}

The towns of Medfield, Wrentham and Unionville doubtless possess the Iargest of the Norfolk county trees. The St. Edwards Elm in Medfield stands in front of the church bearing the same name; the representative elm of Wrentham stands in front of the Cheever Inn; the Unionville EIm is opposite the Unionville post office in the township of Plainville on the edge of a broad green freld. To describe these beautiful trees in detail would be Iargely a repetition of what has gone before, as they possess in large measure the good points of typical elms already described with no marked peculiarities of their own. They are nearly uniform [134] 
in size and the dimensions may be found in the index.

\section{Bristol County}

The white oak on Somerset Ave., Taunton, is Bristol's contribution to the list of famous trees. This oak ranks in size with the white oaks of Waverley, being fifteen feet in circumference and over ninety feet in spread. No other tree in this section is so large, and like most of the aged white oaks of our cities it witnessed the founding of a settlement when the country was very young.

\section{Plymouth County}

We have now retraced our steps from Berkshire to the sea, and the last of the famous trees is also one of the most magnificent in the whole collection. Behold an apple tree having the sinews of an oak, the spread of an elm, and a crown surpassing both in the beauty of its leaves and blossoms! Let the reader imagine it in full bloom, its blossoms nearly the size of wild roses, its largest limbs nearly six feet in

[135] 
girth stretching out thirty feet on every side; its trunk ten feet in girth at the smallest part and fourteen and a half feet at the ground; and he must envy those fortunate residents of Cape Cod who boast that they played under this "umbrella tree" when children and climbed in its branches. It stands on the estate of Mr. Livermore of Marshfield Hills and is known to be more than one hundred years oId, having been planted by Stephen Sherman who was a resident of Marshfreld for nearly ninety years.

At this point the author feels that his book may properly be called completed, and the time for the final word is at hand. It is this - many efforts, both organized and individual, have been made during recent years toward the preservation of all manner of things historic. No effort of any wide scope has yet been made toward the perpetuation of those living monuments which Nature has erected to our past and present history, the famous trees. Therefore, since most books either begin with an object, or, ending, point a moral, be it the purpose of [136] 


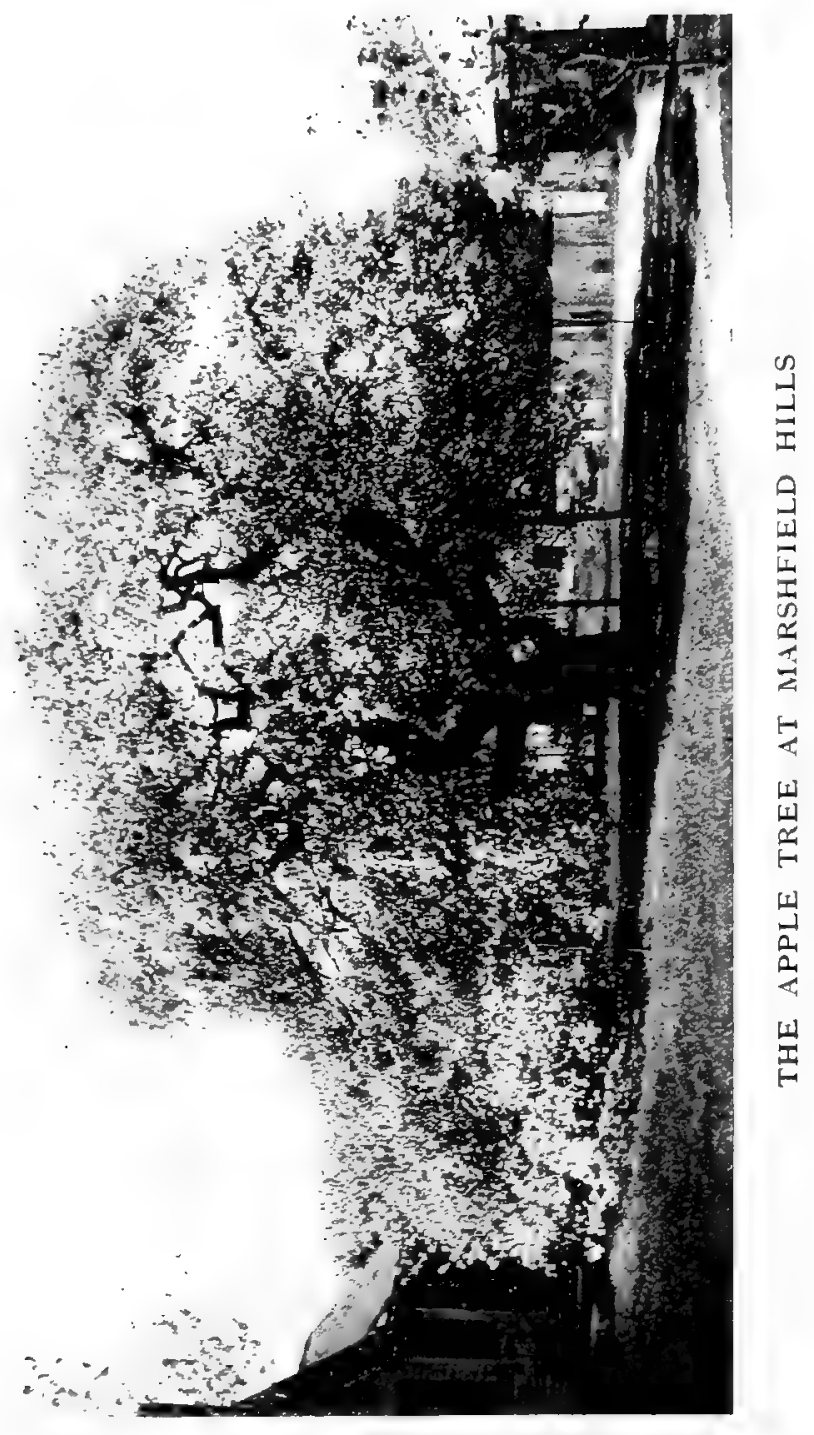





\section{OTHER WELL-KNOWN TREES}

this volume to create, if possible, a sentiment toward the protection and preservation, not only of the historic trees of Massachusetts, but of every state where abound these faithful friends of the Nation. 
THE HISTORIC TREES OF MASSACHUSETTS

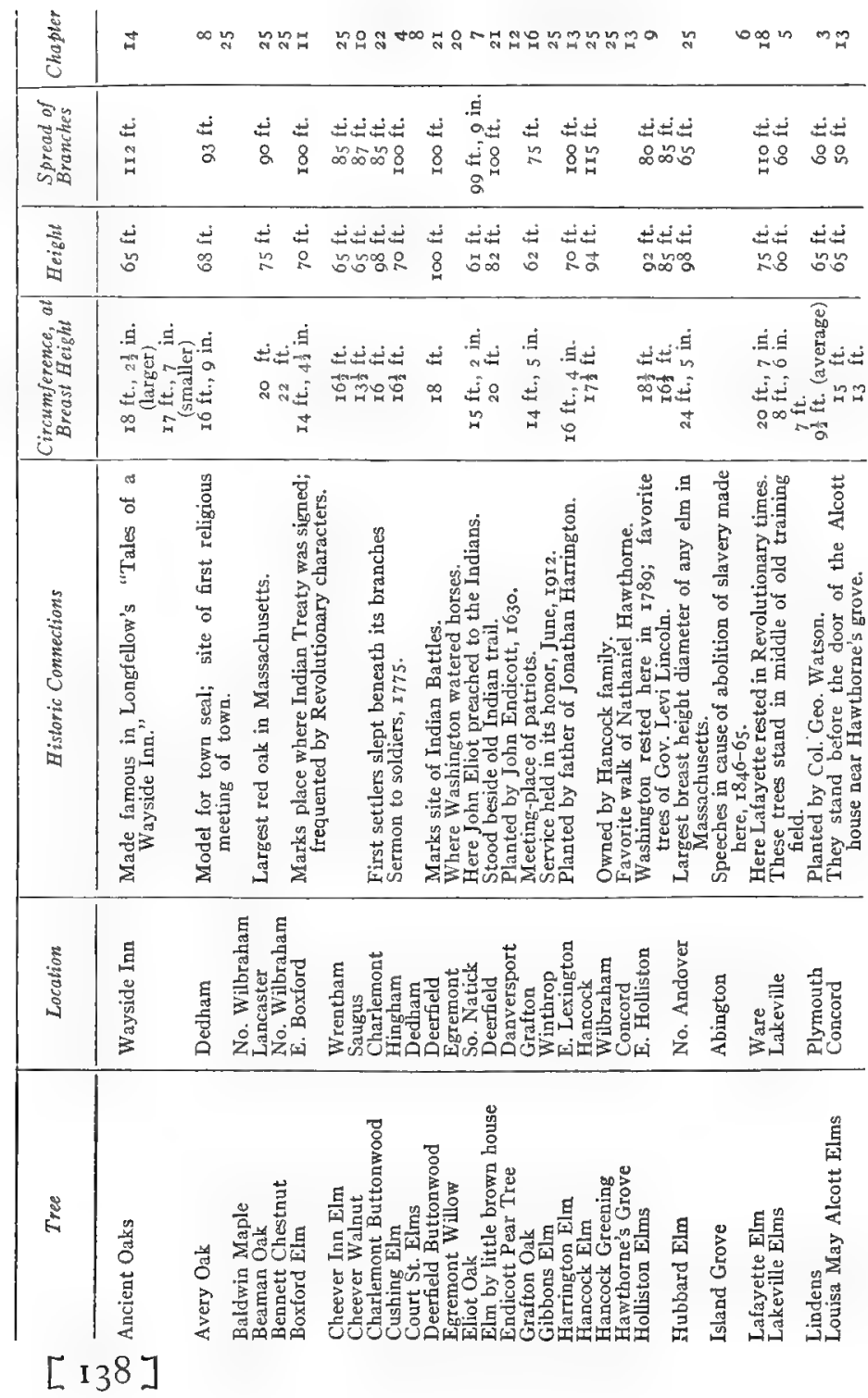




\section{THE HISTORIC TREES OF MASSACHUSETTS}

\begin{tabular}{|c|c|c|c|c|c|c|}
\hline हैं & 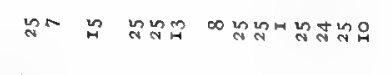 & 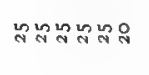 & og & นูㅉำ & " & $\hat{H}$ \\
\hline 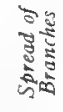 & 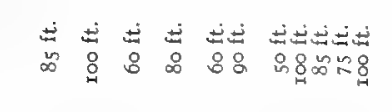 & 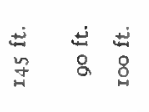 & 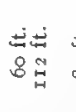 & 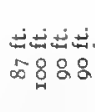 & 年 & $\stackrel{+}{\stackrel{ \pm}{u}}$ \\
\hline 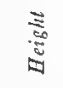 & 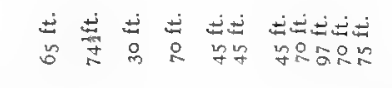 & 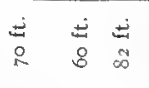 & 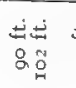 & 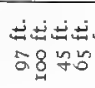 & & 离 \\
\hline $\begin{array}{c}3 \\
0\end{array}$ & 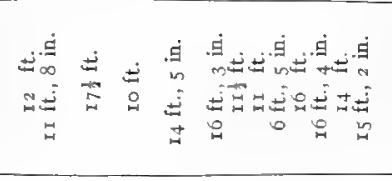 & 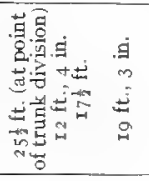 & 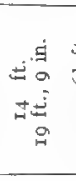 & ن. & is & 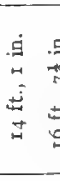 \\
\hline 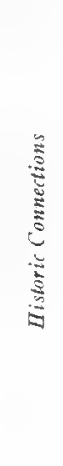 & 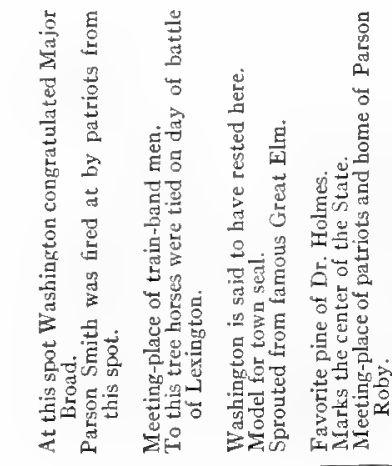 & 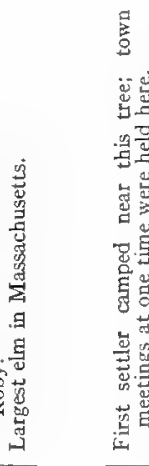 & 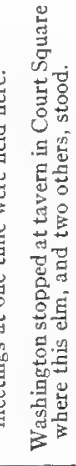 & 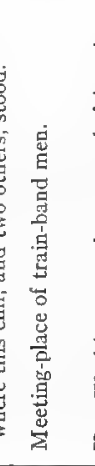 & 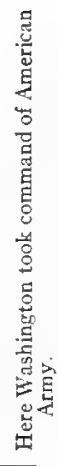 & 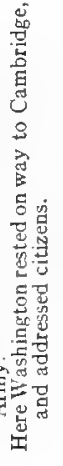 \\
\hline 竎 & 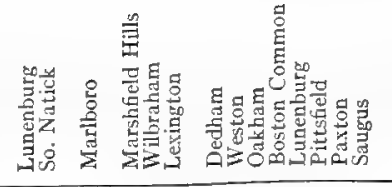 & 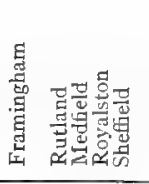 & 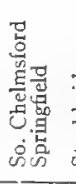 & 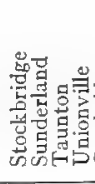 & 然 & 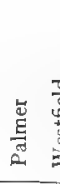 \\
\hline$\stackrel{\square}{2}$ & 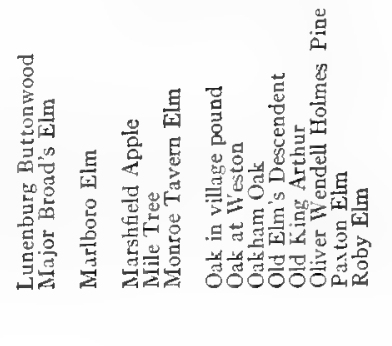 & 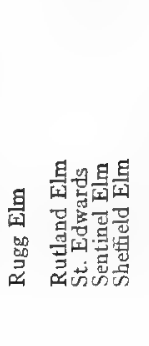 & 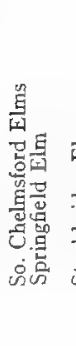 & 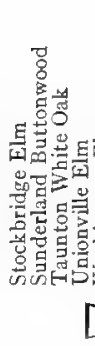 & 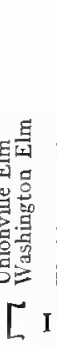 & \\
\hline
\end{tabular}








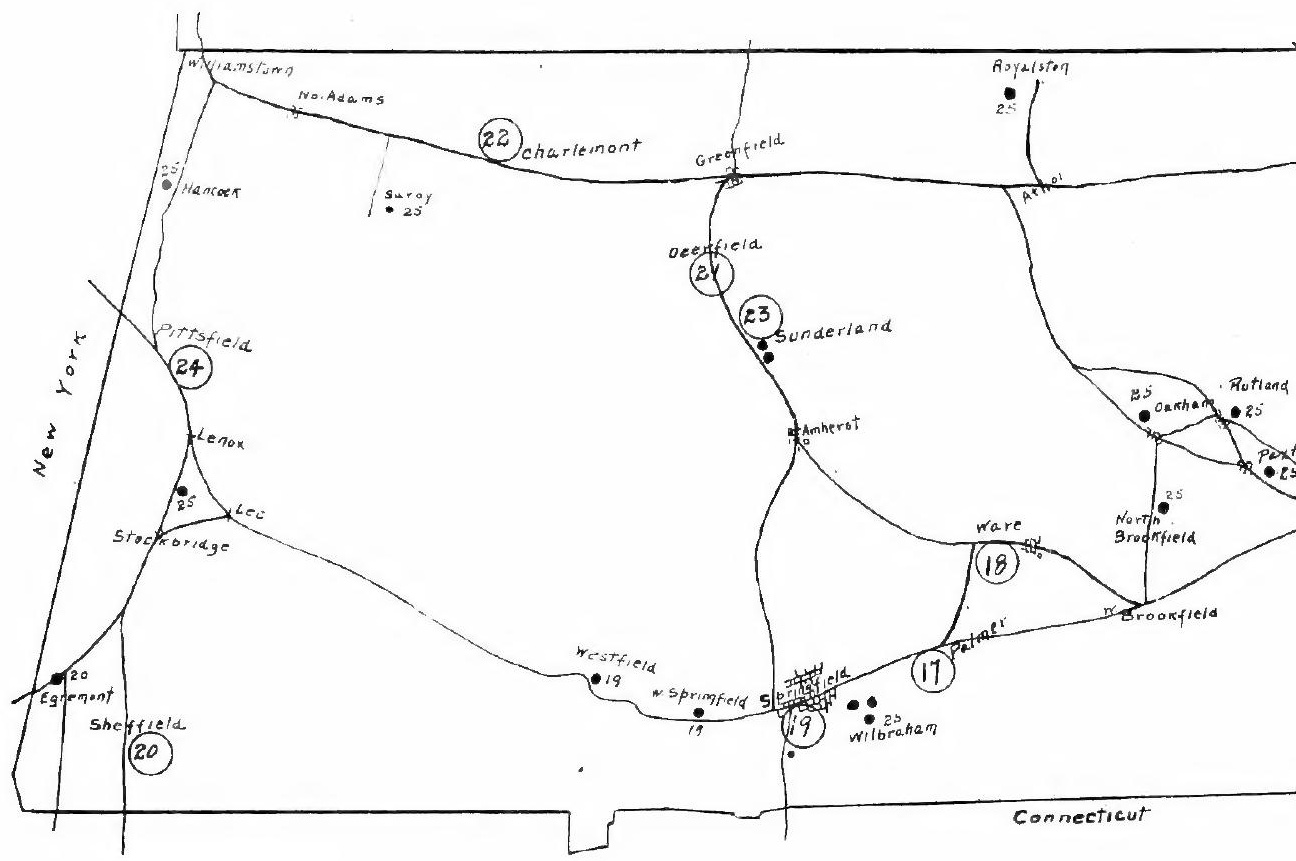

THE HISTORIC TREES OF MASSACHUSETTS.

(HISTOAIC TAEES, Numbers Correspond To Chapters

- OTHEA TREES MENTIONEO IN TEXT:

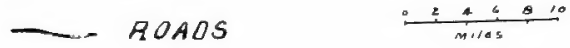




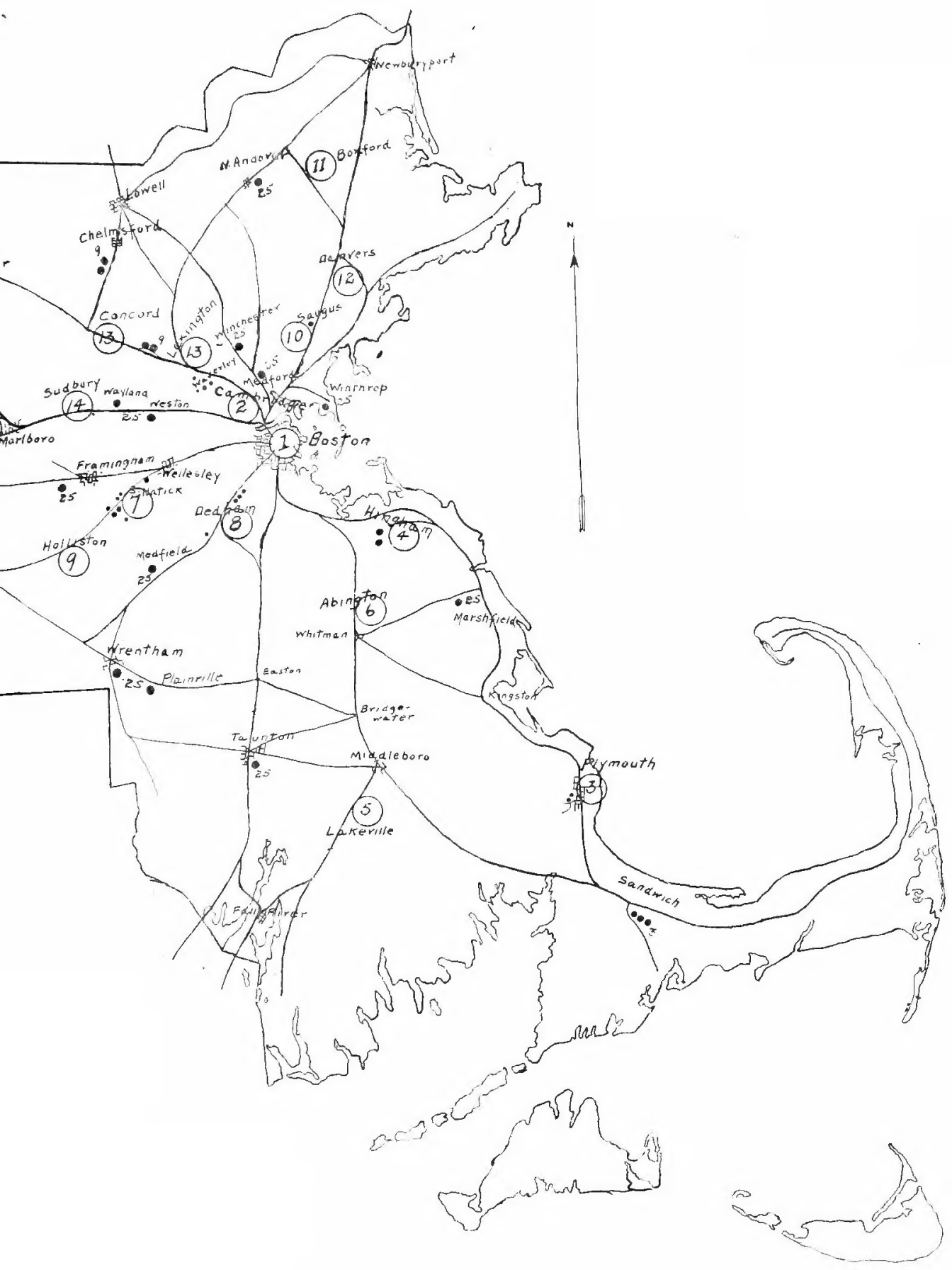


H. 